UNIVERSIDADE DE SÃO PAULO

FACULDADE DE FILOSOFIA, LETRAS E CIÊNCIAS HUMANAS

DEPARTAMENTO DE HISTORIA

PROGRAMA DE PÓS-GRADUAÇÃO EM HISTÓRIA SOCIAL

LAURA LEONOR FIRMIANO TEIXEIRA

\title{
Lívia e Agripina Menor: \\ A presença feminina no jogo político.
}

(Versão Corrigida)

SÃO PAULO

2013 
LAURA LEONOR FIRMIANO TEIXEIRA

\section{Lívia e Agripina Menor: A presença feminina no jogo político.}

(Versão Corrigida)

Dissertação apresentada à Faculdade de Filosofia, Letras e Ciências Humanas da Universidade de São Paulo, para obtenção do título de Mestre em História.

Área de Concentração: História Social

Orientador: Profa. Dra. Maria Luiza Corassin

SÃO PAULO

2013 


\section{FOLHA DE APROVAÇÃO}

Laura Leonor Firmiano Teixeira

Lívia e Agripina Menor: A presença feminina no jogo político.

Dissertação apresentada à Faculdade de Filosofia, Letras e Ciências Humanas da Universidade de São Paulo, para obtenção do título de Mestre em História.

Área de Concentração: História Social

Aprovado em:

Banca Examinadora

$\operatorname{Prof}(\mathrm{a}) . \operatorname{Dr}(\mathrm{a})$.

Instituição

Assinatura

$\operatorname{Prof}(\mathrm{a}) . \operatorname{Dr}(\mathrm{a})$.

Instituição

Assinatura

$\operatorname{Prof}(\mathrm{a}) . \operatorname{Dr}(\mathrm{a})$.

Instituição

Assinatura 


\section{AGRADECIMENTOS}

À minha orientadora, Profa. Dra. Maria Luiza Corassin, por todo o apoio, solicitude e, principalmente, pela paciência durante nossa jornada. Uma historiadora ímpar a quem expresso todo o meu agradecimento pelo amadurecimento, enquanto historiadora, que tive ao longo de todo o nosso trabalho.

À banca, composta pelo Prof. Dr. Breno Battistin Sebastiani e pela Profa. Dra. Elaine Cristina Prado dos Santos, por haver aceitado participar da qualificação e pela inestimável colaboração que deram à pesquisa com suas sugestões.

Ao Prof. Dr. Antonio Henrique Campolina Martins, a quem considero com um verdadeiro pai, pelo carinho, apoio constante e todas as valiosas sugestões durante minha vida acadêmica.

À minha mãe Roseli pelo amor, dedicação e apoio; por me acompanhar em todos os momentos importantes da minha vida; por apoiar minhas escolhas; e por sempre compartilhar minhas alegrias e preocupações.

Aos meus irmãos Raphael e Maria Luiza, por me apoiarem e me ajudarem, sempre desejando minha felicidade e sucesso. 


\section{RESUMO}

TEIXEIRA, L. L. F. Lívia e Agripina Menor: A presença feminina no jogo político. 2013. 127 f. Dissertação (Mestrado) - Faculdade de Filosofia, Letras e Ciências Humanas, Universidade de São Paulo, São Paulo, 2013.

Essa pesquisa almeja explicitar a influência de Lívia e de Agripina Menor, muitas vezes absolutamente política, no período entre 38 a.C. a 59 d.C.; destacando neste processo o uso das mulheres na criação da domus Augusta e na propaganda de Augusto e de outros imperadores da dinastia JúlioClaudiana. Para isto, serão analisados excertos das fontes primárias, especialmente Tácito e Suetônio, nos quais podemos identificar a relevância destas mulheres dentro da família imperial e na sociedade romana.

Palavras-chave: Lívia. Agripina Menor. Domus Augusta. Império romano.

\section{ABSTRACT}

TEIXEIRA, L. L. F. Livia and Agrippina Minor: The feminine presence in the political game. 2013. 127 f. Dissertation (Master's degree) - Faculdade de Filosofia, Letras e Ciências Humanas, Universidade de São Paulo, São Paulo, 2013.

This research aims to make explicit the influence of Livia and Agrippina Minor, an influence very often absolutely political, in the period from $38 \mathrm{BC}$ to $59 \mathrm{AD}$; emphasizing in this process the use of women in the creation of the domus Augusta and in the propaganda of Augustus and other emperors of the JulioClaudian dynasty. For this, excerpts from primary sources will be analyzed, particularly Tacitus and Suetonius, in which we identify the relevance of these women within the Imperial family and in Roman society.

Keywords: Livia. Agrippina Minor. Domus Augusta. Roman Empire 


\section{LISTA DE ABREVIATURAS}

AJA

AJPh

AncSoc

ANRW

Arethusa

Burl. Mag.

CJ

Classica (Brasil)

$\mathrm{CPh}$

$\mathrm{CQ}$

CR

$\mathrm{CW}$

CWe

G\&R

Historia
American Journal of Archaeology : the journal of the Archaeological Institute of America. Boston (Mass.) : Boston University, Archaeological Institute of America.

American Journal of Philology. Baltimore (Md.) : Johns Hopkins University Pr.

Ancient Society. Leuven : Peeters.

Aufstieg und Niedergang der Römischen Welt. Berlin - New York, 1972.

Arethusa. Baltimore (Md.) : Johns Hopkins University Pr.

The Burlington Magazine for Connoisseurs. The Burlington Magazine Publications Ltd.

The Classical Journal. Ashland (Va.) : RandolphMacon College, Department of Classics, Classical Association of the Middle West and South.

Classica : revista brasileira de estudos clássicos. São Paulo : Sociedade Brasileira de Estudos Clássicos.

Classical Philology : a journal devoted to research in classical antiquity. Chicago (III.) : University of Chicago Pr.

Classical Quarterly. Oxford : Oxford University Pr.

Classical Review. Oxford : Oxford University Pr.

Classical World. Pittsburgh (Pa.) : Duquesne University, Department of Classics, Classical Association of the Atlantic States.

Classical Weekly. Pittsburgh (Pa.) : Duquesne University, Department of Classics, Classical Association of the Atlantic States, 1907-1957.

Greece and Rome. Oxford : Clarendon Pr.

Historia : Zeitschrift für Alte Geschichte = revue d'histoire ancienne. Stuttgart : Steiner. 
Helios

JRAI

JPGMJ

JRS

MAAR

Mnemosyne

Phoenix

TAPhA

TAPhS

\section{Fontes Primárias}

Dio Cas. Hist.

Plut. Ant.

Suet. Calig.

Suet. Aug.

Suet. Claud.

Suet. Galb.

Suet. Nero

Suet. Oth.

Suet. Tib.

Tac. Ann.

Vel. Hist.
Helios : a journal devoted to critical and methodological studies of classical culture, literature and society. Lubbock (Tex.) : Texas Tech University Pr.

Journal of the Royal Anthropological Institute of Great Britain and Ireland. Royal Anthropological Institute of Great Britain and Ireland.

The J. Paul Getty Museum Journal : J. Paul Getty Trust.

The Journal of Roman Studies. London : Society for the Promotion of Roman Studies.

Memoirs of the American Academy in Rome. Ann Arbor (Mich.) : University of Michigan Pr.

Mnemosyne : bibliotheca classica Batava. Leiden : Brill.

Phoenix : journal of the Classical Association of Canada $=$ revue de la Société canadienne des études classiques. Toronto (Ont.) : University of Toronto Pr.

Transactions of the American Philological Association. Baltimore (Md.) : Johns Hopkins University Pr.

Transactions of the American Philosophical Society. Philadelphia (Pa.) : American Philosophical Society.

Dion Cássio, Historiae Romanae

Plutarco, Antonius

Suetônio, Caligula

Suetônio, Augustus

Suetônio, Claudius

Suetônio, Galba

Suetônio, Nero

Suetônio, Otho

Suetônio, Tiberius

Tácito, Annales

Veleio Patérculo, Historiae Romanae 


\section{SUMÁRIO}

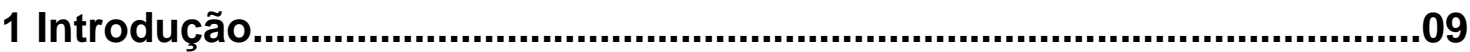

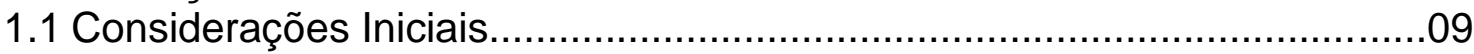

1.2 Tácito e a as mulheres nas fontes primárias...........................................11

1.3 Considerações sobre Suetônio...........................................................14

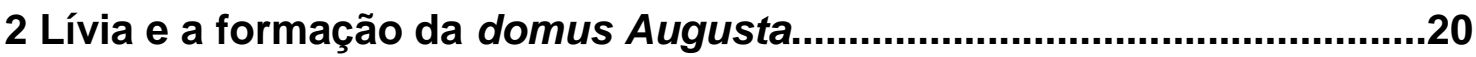

2.1 O contexto sócio-político: A ascensão de Augusto e a crise do fim da

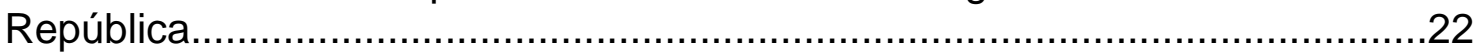

2.2 O Casamento com Otaviano e a primeira aparição pública........................28

2.3 A relação familiar de Lívia com Augusto e o poder.....................................37

3 Lívia e a política sucessória dentro da domus Augusta.........................52

3.1 A morte de Augusto e a ascensão de Tibério ao poder..............................53

3.2 A relação entre mãe e filho: a influência de Lívia no governo......................64

3.3 - As relações de poder na corte: as mulheres da domus Augusta durante 0 fim do principado de Tibério e 0 principado de

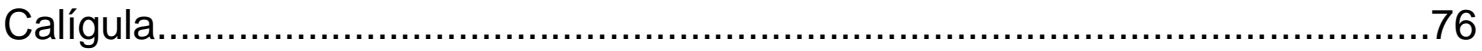

4 Agripina Menor: uma mulher consciente da dinâmica da domus

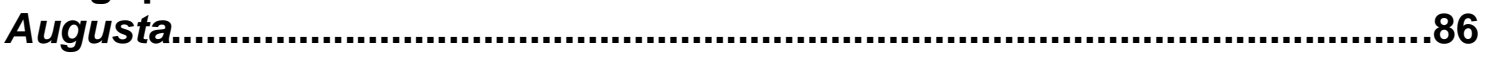
4.1 O retorno do exílio: o segundo casamento e os conflitos na corte

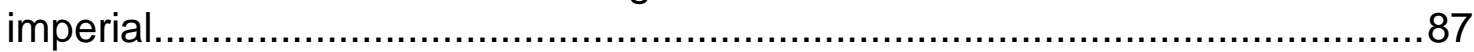
4.2 Relações de poder com Cláudio: o casamento como forma de vinculo a

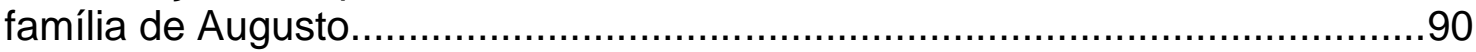
4.3 Agripina e Nero: da influência materna ao fim da dinastia........................101

5 Conclusão

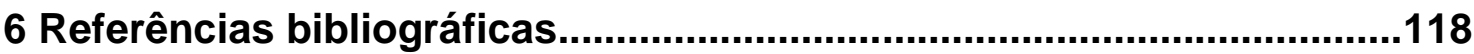

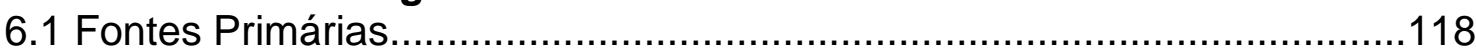

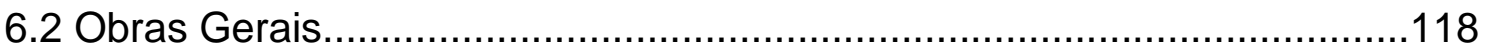

7 Anexos (s) 


\section{Introdução}

\subsection{Considerações iniciais}

Esta pesquisa tem por objetivo explicitar a influência, muitas vezes absolutamente política, de duas mulheres da família imperial no período entre 38 a.C. a 59 d.C.; datas que abrangem o casamento de Lívia com Augusto, até a morte de Agripina Menor. Neste trabalho pretende-se mostrar que apenas considerar a posição delas na família - como mãe ou esposa - não basta para compreender a relevância e o poder adquirido por elas; é necessário entender uma nova dinâmica em que a construção da imagem da família imperial por Augusto é de extrema importância. Desta forma o trabalho será dividido em três capítulos, precedidos por esta introdução e complementados por considerações finais.

Nesta introdução apresentaremos algumas questões relativas às fontes primárias utilizadas em nossa pesquisa, os "Anais" de Tácito e a "As Vidas dos Doze Césares" de Suetônio. E também destacaremos algumas considerações sobre as mulheres nestas obras.

Em um segundo momento, apresentaremos Lívia e sua vida enquanto esposa de Augusto, considerando as questões políticas do começo do governo de Otaviano, bem como a propaganda que incluía os familiares especialmente as mulheres. Destacaremos as diferenças nas narrações de Suetônio sobre o casamento dela e como isto define um tom em cada biografia do autor em que ela também é citada. Trataremos também de sua relevância e influência dentro da família, especialmente com o esposo, e de que forma a união de sua família com a família de Otaviano deu origem à domus Augusta.

No capítulo seguinte vamos estudar a posição de Lívia como mãe do novo imperador - Tibério - e como ela foi relevante para a sua adoção. Apresentaremos suas ações enquanto membro relevante da domus e especialmente com relação à neta de Augusto, Agripina Maior. Estudaremos este conflito dentro das duas famílias e que explicita a formação de uma 
espécie de corte - pelas múltiplas uniões das duas famílias entre si e com outras relevantes famílias romanas - em que o jogo político é associado com intrigas e a defesa (ou ainda criação) de posições dentro da domus Augusta baseadas na ascendência, especialmente o vínculo com o sangue de Augusto. A posição de Lívia permitiu auxiliar amigos e mesmo protegê-los, como o caso de Urgulânia ou mesmo o julgamento de Plancina.

Apresentaremos, neste mesmo capítulo, a segunda mulher pesquisada neste trabalho, Agripina Menor. Sabemos algumas informações sobre seu primeiro casamento, que também seguia a dinâmica de casamentos entre parentes iniciada por Augusto; entretanto, não possuímos maiores detalhes sobre seu posicionamento com relação ao conflito entre sua mãe e sua bisavó. Todavia, no período inicial do principado do irmão Calígula, ela e suas outras duas irmãs encontram-se em posições relevantes, possuindo grande influência e recebendo honras. No final do capítulo vemos que novamente o jogo de poder é responsável por conflitos dentro da família; Agripina Menor é exilada após ser acusada de conspirar contra o irmão Calígula.

No último capítulo estudaremos Agripina Menor como esposa do imperador Cláudio e como mãe do imperador Nero. Depois de retornar de seu exílio, ela vai se casar com o tio e imperador destacando sua ascendência nobre e mostrando que sabe fazer uso das intrigas dentro da corte e de aliados. Estudaremos sua relevância enquanto esposa do imperador e as acusações feitas a ela já nesse período; Agripina é acusada de realizar diversos ataques, especialmente contra mulheres tidas como potenciais concorrentes à sua posição. A ela também é atribuída à ascensão de Nero ao poder, fazendo com que o marido auxiliasse sua carreira, casando-o com sua filha Otávia e depois o adotando como filho (Otávia foi adotada em outra família para não constituir incesto). Durante o principado de Nero, Agripina teve muita influência inicialmente e estudaremos os fatores que a levaram a perder esta relevância, bem como os momentos finais de sua vida.

Nas considerações finais traçaremos algumas comparações entre as duas mulheres e suas participações nos principados dos maridos e filhos. Abordaremos também essas relações entre as ramificações familiares que compuseram a domus Augusta e como estas mulheres participaram deste processo, principalmente como se posicionaram nos conflitos e nos jogos de 
poder. Desta forma, compreenderemos que apenas considerar a relevância dessas mulheres por fazerem parte da família imperial - em suas funções maternas ou quaisquer outras (de esposa, irmã, sobrinha, neta, entre outras) -, não basta para explicar a influência que, especialmente Lívia e Agripina Menor, exerceram; torna-se necessário compreender de que forma, e em que momentos, elas exerceram influência ao longo dos governos aos quais estiveram ligadas e como foram utilizadas por uma propaganda iniciada por Augusto.

\subsection{Tácito e a as mulheres nas fontes primárias}

A pesquisadora Suzanne Dixon nos informa que a imagem da mulher romana ideal está presente em diferentes tipos de fonte; alguns epitáfios apresentam a ideia da mulher que deveria ser um firme exemplo de moral e comportamento, ser casta, industriosa e sempre disposta a agradar o marido. Textos literários, históricos ou biográficos, conscientemente nos apresentam bons e maus comportamentos de mulheres e homens ${ }^{1}$. É notável, ainda, que quando uma mulher é apresentada, em uma narrativa histórica, transgredindo de alguma forma seu papel, como por exemplo, uma intromissão política, ela também é associada a uma transgressão sexual.

O comportamento sexual das mulheres é introduzido apropriadamente em cada gênero para servir a um objetivo especifico de humor, sátira social, exemplo moral, boatos, promoção de um enredo ou exploração de um tema elegíaco. Com exceção do discurso médico, hinos matrimoniais, alguns rituais religiosos e das potenciais vitimas de narrativas ou da política, boas mulheres não são usualmente relacionadas a termos sexuais. Mulheres más são quase sempre sexualizadas. $^{2}$

As mulheres são retratadas convencionalmente por alguns textos pelo pressuposto de que se elas violam algum destes ideais de comportamento

\footnotetext{
${ }^{1}$ DIXON, Suzanne. Reading Roman Women: Sources, Genres, and Real Life. London: Duckworth, 2001, p. 33.

${ }^{2}$ DIXON, Suzanne (2001). op. cit., p. 43.
} 
desrespeitará outras, notadamente os ideais sexuais. Devemos, entretanto, considerar que insultos sexuais são uma das formas de controle social utilizado contra as mulheres, acusações de adultério e de aborto de filhos oriundos dessas relações (ou em alguns casos de relações incestuosas) são atribuídas a várias mulheres como forma de ataque ${ }^{3}$.

Dixon destaca que as romanas também se tornaram agentes de decadência para alguns autores; associadas recorrentemente nas narrações a adultérios, planos de assassinato do marido ou de enteados, utilizando roupas inadequadas, comportando-se frivolamente e, obviamente, interferindo em esferas masculinas como a política; ainda existiam aquelas que eram caracterizadas como vitimas de um governante cruel. Assumiam as mulheres, então, ora uma figura de vítima heróica ora uma figura de vilã, sendo essas figuras femininas notórias nos textos de Tácito ${ }^{4}$.

Cornélio Tácito nasceu por volta do ano de 54 d.C., entretanto o local de seu nascimento é incerto. Ele fez sua carreira desde o Período Flávio (69-96 d.C.), tendo chegado ao consulado; entre os anos de 112-113 d.C. foi nomeado procônsul da província da Ásia ${ }^{5}$. Sua obra "Anais" é conhecida parcialmente; as partes referentes ao imperador Calígula, ao início do principado de Cláudio e ao fim do principado de Nero foram perdidas. $O$ autor faz um julgamento moral mais claro em seu texto, apresentando ao leitor fatos que o levem a concordar com sua visão ao fim da leitura ${ }^{6}$.

O grande tema dos "Anais" é o declínio da domus Caesarum, o declínio moral, a perversão da libertas pelo domínio de homens sem limitações de poder e luxúria ${ }^{7}$; um tema paralelo é a corrupção sob governantes dominados por mulheres. Já que o princeps supostamente deve garantir a libertas, qual a esperança para uma nação na qual ele é subjugado por uma mulher? A Roma do período Júlio-Cláudio vinha sofrendo de uma contínua ascensão feminina dentro da família imperial e da enorme influência delas sob o poder masculino, absolutamente contrário à ordem natural do universo entendida por Tácito, e

\footnotetext{
${ }^{3}$ DIXON, Suzanne (2001). op. cit., p. 36-40, 59-64.

4 Ibidem, p. 56-58; 64.

${ }^{5}$ MELLOR, Ronald. Tacitus. New York: Routledge, 1993, p. 6-7.

6 Ibidem, p. 65.

${ }^{7}$ BENARIO, Herbert W. Tacitus and the Principate. CJ, v. 60, n. 3, Dec. 1964, p.97-106.
} 
era previsível o declínio e destruição dessa dinastia ${ }^{8}$. Seu trabalho consiste em bem mais que uma história sobre os imperadores. Ele observa quadros anuais e ainda dedica certa atenção a questões provinciais ${ }^{9}$. Tácito se vale de uma imparcialidade por escrever sem censuras sobre os governantes tratados. $O$ autor utiliza fontes como arquivos senatoriais, discursos, biografias ${ }^{10}$, cartas e seus contemporâneos. O historiador usa também de alguns boatos, porém pode desmenti-los imediatamente ou usá-los para comprovar algo como o ódio a algum imperador ou alguma falha de caráter ${ }^{11}$.

A contínua ascensão feminina citada anteriormente pode ser explicada pelo estudo da pesquisadora Mireille Corbier, que demonstra a construção de uma domus Augusta. Esta domus era construída por meio de casamentos utilizando as mulheres da família, tendo em vista que Augusto não possuía um filho homem, biológico. Esta construção não buscava apenas a criação de uma descendência legitima dentro do próprio grupo (as famílias Júlia e Cláudia, por intermédio do casamento com Lívia), buscava também a obtenção de apoio político por meio da inclusão de relevantes famílias a essa domus Augusta. Desta forma, por meio de irmã, filha, netas, sobrinhas e outras mulheres da família, Augusto - utilizando o poder de paterfamilias - pode tecer diversas conexões que criaram diversos apoios políticos e uma família que permaneceu no poder ao longo de cinco gerações ${ }^{12}$.

Judith Ginsburg em seu estudo sobre Agripina Menor apresenta as formas como ela é tratada nos "Anais" de Tácito, como sendo especialmente um agente de decadência do governo. Ginsburg destaca que existem alguns estereótipos principais para esta mulher na obra de Tácito, especialmente o de madrasta cruel e de transgressora sexual. A autora apresenta que a figura da madrasta está estabelecida em Roma devido à possibilidade de divórcio e realização de novos matrimônios; a visão negativa dela ganha espaço na literatura quando são descritas em meio a intrigas para obter benefícios para seus filhos e preterir os enteados, chegando até mesmo a tramar a morte do

\footnotetext{
${ }^{8}$ L'HOIR, Francesca Santoro. Tacitus and Women's Usurpation of Power. CW, v. 88, n. 1 , Sep.- Oct. 1994, p. 5-25.

${ }_{9}$ DOREY, T. A. (ed.). Latin Biography. London: Routledge, 1967, p. 82.

${ }^{10}$ Vale-se da biografia escrita por Agripina Menor, por exemplo. MELLOR, Ronald. op. cit., p. 34.

${ }_{11}^{11}$ MELLOR, Ronald. op. cit., p. 33-38.

${ }^{12}$ CORBIER, Mireille. Poder e parentesco. A família Júlio-Cláudia. Tradução de Consuelo Fontes Santiago. Classica, São Paulo, 5/6, 1992/1993, p.168-169; 176-178.
} 
esposo - geralmente por meio de envenenamento. O estereótipo de transgressora sexual presente nas descrições de Agripina faz parte de sua busca pelo poder. Suas transgressões podem ser divididas em dois tipos, de acordo com Ginsburg, o incesto e o adultério. Os, supostos, incestos foram cometidos com o irmão Calígula, o tio Cláudio e com seu filho Nero e demonstram a degeneração da família ao cometer um ato abominável para os romanos. Como destaca a autora, os adultérios mostram a inabilidade do marido em controlar uma esposa e quando pensamos nesse marido como o imperador pode-se deduzir que se ele não garante a ordem na própria casa, não conseguirá manter a ordem em Roma. Mesmo sendo estas imagens atribuídas principalmente à Agripina, Lívia também pode ser incluída na interpretação da figura de madrasta que está presente em Tácito $^{13}$.

\subsection{Considerações sobre Suetônio}

As primeiras biografias e autobiografias gregas são do período entre 500 a.C. e 480 a.C., e mesmo sem abundantes evidências é possível dizer que existiam trabalhos fora da esfera das biografias literárias e mitológicas, como destaca o historiador Arnaldo Momigliano. Outra relevante questão do período, segundo o autor, é o desenvolvimento de uma nova noção de História com base, especialmente, em três elementos: a curiosidade sobre as instituições e terras estrangeiras; as dúvidas sobre genealogia e sobre os tradicionais mitos; e o interesse sobre os vários tipos humanos. Os estudos sobre locais, costumes, vocabulário e outros temas continuavam existindo no século $\mathrm{V}$ a.C., mas eram menos influentes que os estudos da história política ${ }^{14}$.

Segundo o historiador, de uma forma geral, o pouco que conhecemos dos escritos biográficos acabam pertencendo a um desses três elementos da pesquisa histórica. Havia alguns relatos sobre contemporâneos relevantes,

\footnotetext{
${ }^{13}$ GINSBURG , Judith. Representing Agrippina: Constructions of Female Power in the Early Roman Empire. Oxford and New York: Oxford University Press, 2005, p.123; 130-132. RUTLAND, Linda W. Women as Makers of Kings in Tacitus' Annals. CW, v. 72, n. 1 Sep., 1978, p. 22.

${ }^{14}$ MOMIGLIANO A. The development of Greek Biography. Cambridge, Massachusetts: Harvard University Press, 1971, p. 23-32; 101.
} 
outros sobre figuras literárias; o interesse por tais personagens poderia ser por uma mera curiosidade, porém poderia ser pela investigação da natureza e do significado da poesia de um escritor ou mesmo da sabedoria de um homem. Havia, ainda, a tentativa de organizar as vidas dos heróis míticos ${ }^{15}$.

As escolas filosóficas e retóricas do século IV a.C. desenvolveram a arte de falar sobre o individual; encômios e biografias idealizadas eram feitos sobre monarcas e filósofos e nelas encontravam-se fatos e ficção livremente misturados. A linha divisória entre fato e ficção era tênue na biografia, os leitores provavelmente esperavam encontrar informações sobre educação, relacionamentos amorosos e outras informações que possuem pouquíssima documentação. Entretanto, mesmo com este desenvolvimento ambíguo Momigliano considera que a exploração do individual fez enorme progresso neste período ${ }^{16}$.

Ainda no quarto século, Aristóteles percebe que a coleta de dados autênticos sobre os indivíduos poderia contribuir para sua própria filosofia, bem como com a poética, a moral e a política; os dados coletados por ele e seus discípulos respondiam a questões precisas e ele ainda substituía narrações de fatos não vinculados por análises sistemáticas. Os boatos são destacados por serem apreciados tanto por Aristóteles quanto por seus discípulos; fazendo uso de anedotas para ilustrar vícios e virtudes deles, entretanto um conjunto de boatos não configura uma biografia. Aristóxenes foi o primeiro autor que fez das anedotas parte essencial das biografias - mesmo que existam conjuntos de boatos que não são biografias e biografias que não possuem anedotas -, ele provavelmente conhecia as biografias do quinto século e as evoluções do quarto século, associado ainda às pesquisas eruditas estimuladas por Aristóteles ${ }^{17}$.

A autobiografia foi utilizada por reis e políticos helênicos como instrumentos de autoafirmação e defesa, os políticos romanos fizeram este mesmo uso já no século II a.C.. Os romanos eram acostumados a fazerem elogios aos seus ancestrais, destacando sua origem e desta forma a autobiografia começou a ser difundida. Já a biografia em Roma data do século

\footnotetext{
${ }^{15}$ MOMIGLIANO A. op. cit., p. 102.

${ }^{16}$ Ibidem, p. 43-57; 102.

17 Ibidem, p. 66-77; 103.
} 
I a.C. com nomes como Cornélio Nepos e Varrão, que compararam romanos e gregos nas biografias e representações. Algumas poucas evidências levam os autores a compreender como uma das influências da autobiografia romana as representações realísticas feitas de cera dos ancestrais, por serem autoexposições. Porém, a valorização da ascendência é uma das influências dos escritos biográficos. Os romanos costumavam a escrever sobre seus antepassados como forma de valorização pessoal; ainda, poderiam escrever autobiografias para o benefício de seus descendentes. Essas biografias dos ancestrais ou mesmo dos contemporâneos poderiam, também, ser escritas ou auxiliadas pelos libertos ou pela clientela ${ }^{18}$.

Os escritos biográficos de Varrão foram perdidos, todavia devido a algumas comparações presentes na literatura antiga considera-se que ele escreveu curtas biografias de poetas romanos, conhecemos mais de sua obra Imagines em que há a seleção de centenas de retratos seguidos de uma epígrafe caracterizando o homem em questão. Cornélio Nepos escreveu a primeira coleção de biografias conhecida, comparando gregos e romanos, incluindo alguns cartagineses e persas; biografias de reis estrangeiros eram seguidas de biografias de reis romanos e assim se dava com políticos, generais e outros; escritos sobre estrangeiros eram seguidos de seus correspondentes sobre os romanos. As biografias ganharam prestígio no período imperial, pois serviam ao propósito de contar a história dos Césares sendo também utilizadas para ideias filosóficas. Por manter a Biografia separada da História, gregos e romanos puderam apreciar o que constrói um poeta, um filósofo ou um imperador e puderam apreciar o que permanecia humano nestes homens ${ }^{19}$.

A diferença entre a História e a Biografia no período antigo residia no fato de que a História ocupava-se majoritariamente dos assuntos políticos e militares, tratados de forma cronológica. Mesmo quando a História era dominada por um único homem continuaria a tratar as questões políticas que 0 envolvia. Já as biografias poderiam ou não seguir a cronologia; e o tipo que

\footnotetext{
${ }^{18}$ MOMIGLIANO A. op. cit., p. 93-103. BAKHTIN, Mikhail. Questões de literatura e de estética: a teoria do romance. Traduzido por Aurora Fornoni Bernardini et al. São Paulo: Hucitec, 2002, p. 256.

${ }^{19}$ MOMIGLIANO A. op. cit., p. 93-103.
} 
utilizava rubricas, associado principalmente a Suetônio, era conhecido desde o século II a.C., entretanto não se pode precisar sua origem ${ }^{20}$.

Caio Suetônio Tranquilo nasceu entre os anos de 68 e 71 d.C. e devido a inscrições em uma cidade no Norte da África considera-se que ali tenha sido o local de seu nascimento e que posteriormente teria partido para a cidade de Roma - onde teria sido educado -, entretanto ainda se tem questionamento entre os pesquisadores ${ }^{21}$. Ele seguiu uma distinta carreira equestre, tendo atuado no período de Trajano e Adriano. Ocupou cargos como o de a studiis (funcionário responsável por efetuar pesquisas para o imperador antes que ele respondesse a pedidos; ainda escrevia discursos e dava conselhos referentes à oratória); a bibliothecis (guardião da biblioteca imperial); e ainda o cargo ab epistulis (um secretário imperial, que era responsável principalmente pelas correspondências do imperador) ${ }^{22}$. Fez parte ainda do ciclo de amizades do senador Plínio, o Moço ${ }^{23}$.

O livro "As Vidas dos Doze Césares" tem em sua divisão análises de dados cronológicos (mesmo não seguindo isso na narração) e eidológicos em cada vida; retratando características físicas, vícios, virtudes, interesses intelectuais, entretenimentos promovidos, relações sociais, casamentos, filhos, origem familiar e dos antepassados, lugar de nascimento, presságios da futura fortuna, obras, jogos realizados e campanhas. As anedotas e pormenores não servem apenas como curiosidades; a escolha deles revela um dispositivo de realce à imagem de cada personagem da forma como a quer transmitir, ao ler um boato o leitor poderá relembrar um dos vícios apresentados de forma a confirmá-lo ou duvidar de sua veracidade, amenizando alguma característica do César em questão ${ }^{24}$. A divisão por rubricas retira os eventos da ordem cronológica e os coloca de acordo com a rubrica para exemplificá-la. Há uma

\footnotetext{
${ }^{20}$ MOMIGLIANO A. op. cit., p. 13; 63; 86-88.

${ }^{21}$ DOREY, T. A. (ed.). op. cit., p. 79. ROLFE, John C. Suetonius and His Biographies. Proceedings of the American Philosophical Society, Vol. 52, No. 209, Apr., 1913, p. 210. PRYZWANSKY, Molly M. Feminine Imperial Ideals in the Caesares of Suetonius. Dissertation (Doctor of Philosophy) - Department of Classical Studies - Graduate School of Duke University, 2008, p. 3-4.

${ }^{22}$ DOREY, T. A. (ed.). op. cit., p. 79-80. PRYZWANSKY, Molly M. op. cit., p. 4. BRANDÃO, José Luís Lopes. Máscaras dos Césares: Teatro e Moralidade nas "Vidas" Suetonianas. Coimbra: Centro de Estudos Clássicos e Humanísticos, 2009, p. 25.

${ }^{23}$ CIZEK, Eugen. Structures et idéologie dans "Les viés dês douze Césars" de Suétone. Bucuresti: Editura Academiei; Paris: Les Belles Lettres, 1977, p. 7.

${ }^{24}$ BRANDÃO, José Luís Lopes (2009). op. cit., p. 73-76. DOREY, T. A. (ed.). op. cit., p. 93.CIZEK, Eugen. op. cit., p. 134-155.
} 
avaliação dos Césares que é feita de forma velada, dando a impressão que o autor apenas nos oferece material e que o "julgamento" final seria do leitor, entretanto ao concluir a leitura da obra é possível notar que ao se opor vícios e virtudes os governantes podem ser qualificados em melhores e piores, como aponta Cizek ${ }^{25}$. Ainda, há uma gradação na disposição dos vícios e virtudes no texto, de forma a apresentar os piores vícios por último e no caso dos imperadores que podem ser classificados de forma positiva as virtudes são descritas após os vícios, como é o caso de Augusto, amenizando a opinião do público ao fim da leitura ${ }^{26}$.

O estilo biográfico dele pode ser descrito como tendo sido influenciado pela abordagem dos estudos da antiguidade, em que a cronologia não era 0 norte e sim as rubricas; os estudiosos da antiguidade pesquisavam detalhes do passado, histórias locais, listas de magistrados, nomes próprios, costumes e para tal valiam-se de fontes como cartas, inscrições, dentre outras fontes. Segundo Brandão o interesse deles era no modelo geral, as práticas e hábitos diários, roupas, jogos, deuses que se veneravam ${ }^{27}$. A obra de Suetônio foi escrita e publicada no período que vai de 119 a 122 d.C., época na qual ele teve acesso à documentação devido aos cargos ocupados ${ }^{28}$.

Segundo a pesquisadora Molly Pryzwansky os papeis das personagens femininas variam nas Vidas de acordo com a posição que as mulheres têm na família, como de mães, filhas, irmãs e outras; elas, ainda, se adaptam a avaliação do imperador em questão, um imperador avaliado como um dos piores pode ter se deixado influenciar por uma mulher considerada má ou mesmo ter subjugado alguma parenta. Esta variação dos papeis é notada na descrição de eventos, como por exemplo, o banimento de Júlia, filha de Augusto; na biografia do pai nos é apresentado o posicionamento dele, sem citar o marido Tibério; já na biografia do marido há informações sobre o adultério que causou o divórcio. Segundo Pryzwansky, Suetônio não mostra Júlia exercendo seus dois papeis simultâneos, de esposa e filha, como ela certamente exercia em seu dia a dia. Este tratamento ocorre, também, com as

\footnotetext{
${ }^{25}$ CIZEK, Eugen. op. cit., p. 154-155.

${ }^{26}$ Ibidem, p.118-134.

${ }^{27}$ MOMIGLIANO A. op. cit., p. 93-103. BRANDÃO, José Luís Lopes (2009). op. cit., p. 33-34; 48.

${ }^{28}$ CIZEK, Eugen. op. cit., p. 12-13.
} 
outras mulheres retratadas nas Vidas ${ }^{29}$; segundo Brandão as biografias tendem a se centrar apenas na pessoa retratada e em suas relações sociais ${ }^{30}$.

Observando as questões expostas anteriormente e ainda as informações presentes em cada trecho utilizado, pretendemos compreender a relevância e influência que Lívia e Agripina Menor exerceram durante o período da dinastia Júlio-Claudiana e dentro da domus Augusta. Utilizaremos as traduções para a língua inglesa presentes na Loeb, tradução de John Carew Rolfe para Suetônio e de John Jackson para Tácito, e as traduções para o português são de nossa autoria.

${ }^{29}$ PRYZWANSKY, Molly M. op. cit., p. 1-53.

${ }^{30}$ BRANDÃO, José Luís Lopes (2009). op. cit., p. 90. 


\section{Lívia e a formação da domus Augusta}

Quando pensamos nas mulheres romanas nos deparamos com alguns nomes específicos, suas relações familiares e suas condutas, geralmente vinculados a comportamentos lascivos. A maior parte das mulheres romanas não está nas fontes primárias e esta ausência significava, em última instância, não estarem envolvidas com assuntos ligados a política, guerras, ou quaisquer outras atividades masculinas.

O local da mulher era o lar, o âmbito privado. Em uma casa, sob o controle de seu marido ou paterfamilias, essa mulher cuidaria dos filhos, das atividades domésticas e ensinaria suas filhas a seguir nesta mesma direção. Provavelmente muitas mulheres seguiram essa dinâmica e seria complicado, para não dizer impossível, contar suas histórias.

Certamente essas não foram as únicas possibilidades das mulheres romanas. O trecho de Veyne a seguir resume brevemente algumas informações sobre mulheres aristocráticas; ele nos informa que essas romanas herdavam a postura do pai; é necessário destacar que esta jovem será uma transmissora de sua estirpe. Mesmo não recebendo o nome da família à qual a mãe pertencia, muitos homens foram lembrados como sendo descendentes de mulheres de relevantes famílias.

$\mathrm{O}$ autor prossegue e informa que algumas eram mais ricas que os maridos e dessa forma puderam recusar a autoridade deste, uma frase forte $\mathrm{e}$ talvez o mais adequado fosse dizer que com suas próprias fortunas elas puderam desenvolver um grande círculo de influência, seja pelo patronato ou pela clientela herdada de sua família e sua própria. Esta influência poderia se estender até mesmo no âmbito político de Roma. Na parte final da citação, Veyne mostra a mulher seguindo o marido em exílios e até mesmo buscando defender seus interesses, destacando por fim o papel materno.

Ser mãe de família constitui uma honrosa prisão e uma dignidade um tanto estreita em que o orgulho de uma jovem nobre se colocará no devotamento. Ora, uma jovem nobre herda o orgulho do pai, que de certo modo a emprestou ao marido (em Roma uma esposa descontente não deixava 0 
marido para "voltar para a casa da mãe", mas sim para a casa do pai). Ao orgulho aristocrático acrescenta-se o da fortuna; ela geralmente possui riquezas que não passam para o marido. Ela se iguala aos homens perante o direito sucessório e a capacidade de testar; tem seu dote. Algumas, mais nobres e mais ricas que o marido, recusavam a autoridade deste; outras até desempenharam um grande papel político, pois, a título de heranças, recolheram junto com o patrimônio todas as clientelas hereditárias de sua estirpe. Houve damas que, não contentes com a dedicação ao marido, mostravam a qualidade de sua raça seguindo-o no exílio e até no suicídio (Sêneca, muito cioso de sua ascendência sobre os que o rodeavam, no suicídio quis exercer sobre a esposa e também sobre seu discípulo Lucílio uma verdadeira chantagem moral); elas eram muito capazes de tomar a defesa dos interesses maritais se 0 esposo era exilado ou precisava se esconder. Mas também podiam adotar um belo dia uma atitude bem menos louvável e sintomática do impasse em que se encontravam: pretextar uma dor, a perda de um filho, para renunciar a toda vida de representação e se enclausurar num luto perpétuo. ${ }^{31}$

Não se pode pensar sobre as romanas de forma simplista, nem mesmo se prender a imagens possivelmente ideais. Mesmo as mulheres que são notórias aos conhecedores do período imperial não podem ser apenas consideradas mulheres lascivas, que usaram de seus amantes para tentar interferir no poder. As mulheres da dinastia Júlio-Claudiana, aqui pesquisadas, fizeram parte do processo de transmissão de poder.

Estas matronas da família imperial transmitiram sua estirpe, a mais importante de todas; elas eram as transmissoras do sangue de Augusto. Sendo isto utilizado por algumas para mostrar seu diferencial das demais mulheres. Ou seja, elas possuíam uma clara compreensão de sua importância para a política romana. Algumas fizeram uso de suas fortunas próprias e da clientela de suas famílias para garantir que seus apoiadores estivessem vinculados ao poder e ainda, para ajudar em uma propaganda familiar. Elas financiaram obras públicas e ajudaram em momentos de crise, fazendo seus nomes conhecidos muito além da cidade de Roma. As mulheres foram muito utilizadas na iconografia; muitas representações foram feitas e espalhadas por todo império e assim existiu, também, um processo de construção e destruição de

\footnotetext{
${ }^{31}$ VEYNE, Paul. O Império Romano. IN: ARIÉS, Philippe e DUBY, George. História da Vida
} Privada: Do Império Romano ao Ano Mil. São Paulo: Companhia das Letras, v.1, 1989, p. 77. 
memórias associadas à muitas mulheres que confirma um importante papel exercido por elas em determinadas dinâmicas da sociedade romana ${ }^{32}$.

Tendo em vista o exposto, nesse capítulo buscaremos estudar a atuação de Lívia Drusila - esposa do imperador Augusto e mãe do imperador Tibério Cláudio Druso - e como esta esteve ligada ao poder durante seu segundo matrimônio. Especialmente em seu caso não se pode partir destas caracterizações comumente atribuídas por algumas fontes às mulheres destacadas. Lívia é apresentada de forma favorável pela maior parte das fontes primárias, assim como é admitida sua relevância.

2.1 O contexto sócio-político: A ascensão de Augusto e a crise do fim da República

Em seu último século, a República romana vivenciou uma série de conflitos de natureza variada; os externos ocorreram contra grupos de escravos revoltosos; contra provinciais descontentes com o domínio romano e contra itálicos que desejavam a cidadania romana.

Essas questões trouxeram à tona pontos como o empobrecimento da população de Roma e da Itália com as convocações ao exército e a exploração das províncias. Eram necessárias algumas mudanças e adaptações no governo romano. Gradativamente a opressão romana nas províncias foi atenuada e, a longo prazo, as elites foram incorporadas ao governo servindo, assim, de sustentáculo da organização político-social do Estado romano. Entretanto a economia permaneceu a mesma, assim como o escravismo, que foi consolidado. A maioria dos conflitos ocorreu de forma isolada e devido à

\footnotetext{
${ }^{32}$ Tratando do contraste entre o grande número de mulheres representadas na iconografia e a presença discreta delas nas fontes literárias. DUBY, G. \& PERROT (Dir.). História das Mulheres no Ocidente. Vol. 1. A Antigüidade. Porto: Ed. Afrontamento, 1990, p. 8-9. Sobre o processo de construção e destruição de memórias das mulheres utilizando as estátuas; a difusão de imagens da mulher e da família; e também o processo de destruição dos rostos da imagem; submersão das estátuas em água por um longo período (refletindo a prática de lançar corpos de condenados e gladiadores mortos no Tibre); e outros tipos de danos a partir da condenação destas mulheres. VARNER, Eric R. Portraits, Plots, and Politics: Damnatio memoriae and the Images of Imperial Women. MAAR, v. 46, 2001, p. 86.
} 
multiplicidade de relações sociais e políticas dos domínios romanos não permitiam coesão entre os revoltosos.

A luta entre itálicos e romanos tem seu crescimento em meados do século II a.C., após o fim da segunda guerra púnica. A população itálica era oprimida pelos impostos romanos e especialmente a massa de camponeses pobres encontrava-se em precária situação econômica. A questão dos itálicos esteve na pauta de alguns dos políticos romanos, como o cônsul Marco Fúlvio Flaco e Caio Graco, buscando ampliar a cidadania e torná-los suas bases de apoio político. No entanto, o ápice do conflito ocorre com a tentativa de ampliação da cidadania proposta pelo tribuno da plebe Marco Lívio Druso ${ }^{33}$ no ano de 91 a.C., intensificando os conflitos pela Itália. A principal aspiração dos revoltosos consistia na conquista da cidadania romana - e dessa forma a isenção do pagamento de impostos -, o que justificava o apoio das camadas superiores itálicas - pensemos na possibilidade de exercer cargos. No ano de 90 a.C. por meio da lex Iulia a cidadania foi estendida a todos os itálicos que permaneceram fieis aos romanos durante os conflitos; no ano de 89 a.C. pela lex Plautia Papiria a cidadania incluía todos os revoltosos que se rendessem. Em 49 a.C. o norte da Itália também recebeu o direito de cidadania.

Em meados do século II a.C. as tensões internas atingiram um grau alarmante, surgindo então, algumas propostas reformadoras. Destaca-se a lei agrária proposta pelo tribuno da plebe Tibério Graco no ano de 133 a.C. que limitava o tamanho das propriedades que se poderia dispor no ager publicus; as terras disponíveis para cidadãos a partir dessas limitações seriam distribuídas para os cidadãos pobres; entretanto continuariam pertencendo ao Estado, uma disposição para prevenir a compra destes territórios por proprietários ricos. Essa medida visava resolver um problema que colocava em risco a manutenção do sistema romano de governo; com os camponeses empobrecidos tornava-se difícil o recrutamento regular deles para o exército.

\footnotetext{
${ }^{33}$ As fontes não são claras sobre essa questão, entretanto é aceito entre os pesquisadores que ele seja o avô de Lívia, esposa do imperador Augusto. Ele teria se tornado pai de Druso Cláudio, pai de Lívia, por meio de adoção. O nome a partir de então pode ser verificado em epígrafes como sendo Marco Lívio Druso Claudiano, filho adotivo do Tribuno da Plebe Marco Lívio Druso e seu pai biológico era Cláudio Pulcro. Considera-se que se não for o pai adotivo de Druso Cláudio, a adoção teria sido feita por algum parente próximo. HUNTSMAN, Eric D. Livia before Octavian. AncSoc, v. 39, 2009, p. 123-135.
} 
Ao longo do final do século II e começo do século I a.C. os conflitos seguiram entre os populares e os optimates, membros das camadas abastadas que se diferenciavam apenas pelas idéias que defendiam. Estes eram confrontos de caráter político, conduzidos inicialmente por meio das assembleias e visando debater questões do exercício do poder político do Estado. Dentre os populares Caio Mário, nos anos de 103 a 100 a.C., realiza uma reforma no exército que permitia o recrutamento do proletariado sem bens, sendo equipados pelo Estado. Ambas as facções mobilizavam-se em torno de lideranças políticas ou militares e na década de 80 a.C. a vitória coube aos optimates com a invasão da cidade de Roma pelo comandante Lúcio Cornélio Sula. As medidas adotadas por ele buscavam garantir o poder do Senado, aumentando em mais 300 o número de senadores e retirando os equestres dos tribunais de averiguação de peculato.

Todos os levantes externos que ocorreram no período associados a conflitos políticos internos da sociedade romana facilitaram a ascensão de lideranças políticas e militares, provenientes das camadas mais abastadas. Nos últimos anos da República destacam-se Cneu Pompeu, Júlio César e Marco Licínio Crasso. Todos obtiveram importantes conquistas para Roma, como o êxito de Crasso ao expurgar a revolta de Espártaco em 71 a.C.; as vitórias no Oriente e a derrota dos piratas nos anos de 67 a 63 a.C. por Pompeu; e o processo de conquista da Gália durante os anos 50 a.C. por Júlio César. Estes três comandantes formaram o primeiro, e ilegal, triunvirato. A guerra civil entre César e Pompeu era uma luta pelo poder dentro do regime vigente, pois Pompeu se colocou ao lado do Senado. O domínio político de Júlio César, após essa guerra era um indício do fim do sistema republicano. Com a morte do ditador e a ascensão de um novo triunvirato ${ }^{34}$ a questão era quem seria seu sucessor político. Seu filho adotivo Otaviano, após a vitória na batalha do Áccio em 31 a.C., torna-se então o único no poder. O historiador Alföldy destaca que esses diversos conflitos, que tinham sua origem no campo, tornaram-se conflitos políticos que levaram ao fim da República e, ainda, levaram ao domínio político de Otaviano.

\footnotetext{
${ }^{34}$ Formado por Marco Antônio, Otaviano e Marco Emílio Lépido.
} 
As características comuns dos conflitos entre cidadãos romanos desde Tibério Semprónio Graco até à batalha de Áccio, esclarecedoras sobre a natureza da crise, são tão dignas de atenção como as crescentes diferenças que reflectem a deslocação da essência da crise do campo predominantemente social para o domínio puramente político. ${ }^{35}$

Otaviano apresentou-se como restaurador da República Romana e da paz, contando com extensa propaganda durante seu governo que the assegurou a consolidação dessa imagem. No ano de 27 a.C. Otaviano renuncia a todos os poderes recebidos nos anos anteriores e deixa a decisão do futuro da República nas mãos do Senado e do Povo de Roma. Dessa forma, em concordância com as leis - como mostra o excerto a seguir - o Senado concede uma série de honras a ele; o título Augusto tem uma conotação divina, porém eles estão lidando com o filho do divino Júlio César ${ }^{36}$. Mesmo recebendo honras e poderes ele não aceitou os poderes contrários a esta idéia (como o de ditador) em conformidade com sua imagem de restaurador da República, e os outros cargos exercidos por ele eram renovados periodicamente pelo Senado.

Evidentemente ele [Otaviano] queria que a res publica fosse entendida como um estado governado pelas leis e não um estado no qual a palavra do princeps fosse a lei simplesmente. ${ }^{37}$

Otaviano recebe o título de Augusto também no ano de 27 a.C.. Ele define melhor a ordem senatorial, fixando os valores de fortuna mínimos para serem admitidos na ordem. Houve a criação de uma série de novos cargos a serviço da administração imperial. Foram criadas algumas magistraturas que cuidavam do abastecimento de Roma, dos incêndios que ocorriam constantemente na cidade, dentre outras; o cargo de rector provinciae - uma espécie de governador de determinadas províncias - e os proconsulados da África e da Ásia eram concedidos a senadores, que poderiam ainda terminar suas carreiras com um segundo consulado ou ainda como prefeito da capital do Império. Outros cargos eram exclusivos paras os membros da ordem

\footnotetext{
${ }^{35}$ ALFÖLDY, Géza. A História Social de Roma. Editora Presença: Lisboa, 1989, p. 96.

${ }^{36}$ EDER, Walter. Augustus and the Power of Tradition. IN: GALINSKY, Karl (ed.). The Cambridge Companion to The Age of Augustus. New York: Cambridge University Press, 2005, p. 24.

${ }^{37}$ EDER, Walter. op. cit., p. 24.
} 
equestre e visavam assegurar o domínio do poder do imperador. Assim, cargos como Prefeito do Egito ou Prefeito do Pretório, de extrema importância, ficariam aos cuidados dos equestres, evitando que membros do Senado que aspirassem ao poder pudessem exercer estes cargos e que pudessem organizar algum levante contra o imperador.

Augusto se torna censor, cuidando do álbum senatorial, controlando a ascensão a essa ordem e assumindo o caráter de restaurador da moral, como mostra o autor Leo Ferrero: "Augusto queria que a renovação do antigo tom moral fosse sentida, embora ele mesmo não a tenha sentido" ${ }^{38}$. Outros títulos de grande importância foram o de pontifex maximus no ano de 12 a.C. e o de pater patriae em 2 a.C.. A função paterna em Roma incluía acompanhar os estudos formais do filho - mesmo que essa seja geralmente exercida pelas mães -, entretanto era prioritariamente a de ser um exemplo moral para os filhos, especialmente os filhos homens. Os pais deveriam ensinar aos seus filhos os valores morais da sociedade romana, nesse processo valer-se de severidade era recomendado. Augusto com sua posição de defensor da tradição romana e dos valores morais antigos recebe - depois de intensa propaganda e atitudes vinculadas a essa restauração - o título de "Pai da Pátria". Não somente isso, Augusto associou os deuses de sua própria família aos do Estado quando foi pontifex maximus, assim como fez com alguns dos membros da domus Augusta; os homens da família exerciam cargos, participavam de campanhas militares e eram parte da propaganda augustana ${ }^{39}$. Durante seu governo há a criação de leis que tratam das questões de casamento e adultério. A princípio é possível pensar que essas leis visavam um aumento da população com direitos legítimos, ou seja, cidadãos. Entretanto é necessário considerar que não há informações suficientes sobre os nascimentos após tais leis que possam confirmar essa hipótese. Considerando,

\footnotetext{
${ }^{38}$ RADITSA, Leo Ferrero. Augustus' Legislation concerning Marriage, Procreation, Love Affairs and Adultery. IN: ANRW: Geschichte und Kultur Roms im Spiegel der neueren Forschungen, II.13. Principat - Recht (Normen, Verbreitung, Materien). Ed. Hildegard Temporini. Berlin: De Gruyter, 1980, p. 283.

${ }^{39}$ DIXON, Suzanne. The Roman Family: Ancient Society and History. Baltimore, Londres: The Johns Hopkins University Press, 1991, p.117. LACEY, W.K. Patria Potestas. In: RAWSON, Beryl. The Family in Ancient Rome: New Perspectives. Londres: Routledge, 1992, p. 139-140. EYBEN, Emiel. Fathers and Sons. In: RAWSON, Beryl (ed.). Marriage, divorce, and children in Ancient Rome. Canberra, Oxford: Humanities research Centre, Clarendon Press, 1991, p. 135-143.
} 
porém, a presença de crianças e da família de Augusto nas representações iconográficas tende-se a aceitar, também, um forte teor propagandista das famílias cidadãs, das famílias com filhos legítimos ${ }^{40}$.

As leis - a saber, lex Iulia de Adulteriis Coercendis de 18 a.C., lex Iulia de Maritandis Ordinibus possivelmente de 18 a.C. ou ainda 17 a.C..$^{41}$ e mais tarde lex Papia-Poppaea de 9 a.C. - proibiam o casamentos de senadores e seus familiares com libertos e de toda pessoa livre com atores, prostitutas ou adúlteros condenados. Adultério, estupro e ofensas sexuais passam a ser considerados crimes públicos - anteriormente eles eram resolvidos dentro do núcleo familiar pela figura do paterfamilias. A partir destas leis, estas questões tornam-se de interesse do Estado e maridos que não se divorciassem de esposas adúlteras poderiam ser proscritos. Estas leis falavam, também, das heranças; após os vinte cinco anos para os homens e vinte e dois para as mulheres, aqueles que não estivessem casados não poderiam receber heranças ou legados daqueles a quem eles não estavam ligados dentro de seis graus de parentesco; já os casados sem filhos receberiam metade da herança destinada ${ }^{42}$.

Ainda tratando sobre as mulheres, tem-se o aumento do prazo para realização de novo matrimônio após a morte do cônjuge ou divórcio. Não há nenhum tipo de registro de descontentamento delas, mas dada a ideia de que em geral as mulheres romanas deveriam se casar e gerar crianças, esses pontos das leis não configuraram uma grande diferença em sua condição. Todavia a possibilidade de não depender de um tutor por gerar três filhos ${ }^{43}$ - ius (trium) liberorum, o "direito (de três) crianças." - representou uma verdadeira mudança em suas condições, possibilitando que algumas mulheres ricas pudessem administrar seus patrimônios e se tornassem relevantes na sociedade. Estas leis trouxeram um descontentamento por parte da ordem

\footnotetext{
${ }^{40}$ GRUBBS, Judith Evans. Women and Law in the Roman Empire: A Sourcebook on Marriage, Divorce and Widowhood. London and New York: Routledge, 2002, p. 84-87. RAWSON, Beryl. Children in The Roman Familia. In: RAWSON, Beryl. The Family in Ancient Rome: New Perspectives. Londres: Routledge, 1992, p. 171; 196.

${ }^{41}$ RADITSA, Leo Ferrero. ANRW, p. 285.

${ }^{42}$ GRUBBS, Judith Evans. op. cit., p. 84. GARDNER, Jane F. Women in Roman Law and Society. Bloomington: Indiana University Press, 1991, p.52; 85-86. EDER, Walter. op. cit., p. 28. CANTARELLA, Eva. Pandora's Daughters: The Role and Status of Women in Greek and Roman Antiquity. Baltimore: Johns Hopkins University Press, 1987, p. 122.

${ }^{43}$ Para as libertas eram necessárias quatro gestações.
} 
senatorial; entretanto permaneceram em voga até mudanças no período de Constantino ${ }^{44}$.

Por mais que estas leis buscassem restaurar a antiga moral romana, elas permitiram ao Estado tornar a vida privada da população em algo público. Questões como o matrimônio, adultério, filhos e principalmente as questões sucessórias ganhavam publicidade em Roma; o Estado se fazia presente dentro dos lares, principalmente, das camadas aristocráticas ${ }^{45}$. Entretanto, ao tornar estes pontos públicos e ligar a forte propaganda pacificadora vinculada a sua imagem, a família de Augusto torna-se também de interesse público, as crianças figuram nos triunfos e eventos; as mulheres ganham estátuas e suas atitudes são tomadas como exemplos de conduta; os jovens procuram obter êxitos militares. Desta forma figuras, que normalmente eram ignoradas nas fontes primárias, vão ganhando mais destaque. A consolidação do sistema social por meio do império ocorre a partir do principado de Augusto. Sua figura de imperador e a casa imperial situavam-se no topo da hierarquia social, sobrepondo-se à camada dominante anterior, um pequeno círculo de famílias rivais provenientes das oligarquias.

\subsection{O Casamento com Otaviano e a primeira aparição pública}

Lívia Drusila nasceu provavelmente entre os anos de 59 a.C. e 58 a.C. e era membro da prestigiosa gens Claudia. Esta família, de acordo com lendas, teria ajudado Enéias a estabelecer-se na Itália após a fuga de Tróia. Por volta dos anos 200 a.C. a família se divide em dois ramos, os Cláudios Neros e os Cláudios Pulcros - sendo este último grupo proeminente na política romana - e com seu primeiro casamento Lívia passa a unir novamente os dois ramos ${ }^{46}$. A importância dessas famílias é explicitada na seguinte passagem de Suetônio que descreve a origem familiar do imperador Tibério Cláudio Druso:

\footnotetext{
${ }^{44}$ GRUBBS, Judith Evans. op. cit., p. 84-87. GARDNER, Jane F. op. cit., p. 20-21; 194-198. CANTARELLA, Eva. op. cit., p. 123-124.

${ }^{45}$ DIXON, Suzanne (1991). op. cit., p.78. RADITSA, Leo Ferrero. op. cit., p. 282. EDER, Walter. op. cit., p. 28.

${ }^{46}$ BARRETT, Anthony A. Livia: First Lady of Imperial Rome. New Haven: Yale University Press, 2002, p. 3-5. HUNTSMAN, Eric D. op. cit., p. 131.
} 
Essa era a família pela qual Tibério César tinha origem, pelos dois lados: pelo paterno descendia de Tibério Nero; pelo materno de Ápio Pulcro; ambos eram filhos de Ápio Cego. Ele também era membro da família Lívia, por meio de uma adoção de seu avô materno. Esta família também, embora de origem plebéia, era de grande destaque e foi honrada com oito consulados, duas censuras, três triunfos, assim como os cargos de ditador e um mestre de cavalaria ${ }^{47}$. (Suet. Tib. 3,1 )

O primeiro casamento de Lívia foi com Tibério Cláudio Nero - que, também, era descendente da prestigiada família Cláudia e tido como um jovem promissor na política - e estima-se que tivesse ocorrido por volta do ano de 43 a.C. em meio às tensões geradas pelo assassinato de César ${ }^{48}$. Tensões essas que foram de extrema importância para a família de Lívia; ao optar permanecer ao lado de Marco Antônio esta sofre proscrições. Não é possível ter certeza se Lívia acompanhou o marido em seu exílio, porém após o casamento de Otávia 49 e Marco Antônio em 40 a.C. a família pode retornar a Roma ${ }^{50}$.

O encontro de Lívia e Otaviano não pode ser precisado, porém, acreditase que eles possam ter se conhecido por meio de Escribônia, até então esposa dele ${ }^{51}$. Deixando de lado as possíveis implicações emocionais desse matrimônio - o profundo amor que supostamente eles sentiam um pelo outro durante toda a união ${ }^{52}$-, Lívia casou-se com Otaviano no ano de 38 a.C. e já nessa época possuía um filho, Tibério Nero, nascido em 42 a.C. e estava grávida de seu segundo filho, Nero Cláudio Druso. Esta criança veio a nascer meses após o casamento e ambos os filhos permaneceram com o pai - que reconheceu o nascido após o divórcio -, Tibério Cláudio Nero, até a data de sua

\footnotetext{
${ }^{47} \mathrm{Em}$ ocasiões excepcionais em Roma poderia haver um Ditador pelo período de seis meses. Junto desse cargo um Mestre de Cavalaria era nomeado para auxiliar no governo.

${ }^{48}$ BARRETT, Anthony A. (2002). op. cit., p. 11. HUNTSMAN, Eric D. op. cit., p. 137.

49 "Otávia" é como Otávia Menor aparece nas fontes primárias, sabemos, entretanto, que Augusto tinha duas irmãs. Sobre Otávia Maior, sua irmã por parte de pai, quase não possuímos dados. Todas as informações presentes nesse trabalho são sobre Otávia Menor. SINGER, Mary White. The Problem of Octavia Minor and Octavia Maior. TAPhA, v. 79, 1948, p. 268274.

${ }^{50}$ BARRETT, Anthony A. (2002). op. cit., p. 17-18.

${ }^{51}$ Um primo ou possivelmente um irmão de Escribônia foi adotado pelo pai de Lívia; dessa forma considera-se que ambas possam ter uma rede de conhecidos em comum e a partir dessa Lívia teria conhecido Augusto. HUNTSMAN, Eric D. op. cit., p. 141-145.

${ }^{52}$ Suet. Aug. 62, 2.
} 
morte por volta de 33 ou 32 a.C. ${ }^{53}$. O matrimônio de Augusto e Lívia não pode ser pensado sem considerar a importância política de tal união; a família dela era muito importante. Isto garantia a Otaviano um importante reforço em sua base de poder, como destaca Barrett:

\begin{abstract}
$\mathrm{Na}$ verdade, Lívia parece ter sido uma parceira ideal. Independentemente de qualquer sentimento de afeto, ela trouxe significativos benefícios políticos para o casamento. Otaviano tinha um poder considerável. Sua necessidade desesperada agora era de status. (...) Isso ligaria Otaviano com a poderosa e prestigiada família Cláudia. Mas, além disso, as conexões com Lívio Druso ${ }^{54}$ ressoariam por toda a Itália e ajudariam a reforçar a base de poder de Otaviano. Vale a pena notar que os nomes Druso e Drusila, ambos parte da linhagem Lívia, continuaram a ser utilizados por diversas gerações da família. ${ }^{55}$
\end{abstract}

Não se trata apenas de um reforço em sua base de poder na Itália, mas também uma forte ligação com a aristocracia romana, pois Otaviano estava se casando com uma mulher da família Cláudia. Após a morte de seu pai adotivo, Júlio César, ele precisou estabelecer diversos vínculos para garantir seu poder, tendo em vista que apenas tinha iniciado sua vida política. Ele manteve a existência dos cargos senatoriais, além de criar alguns outros para gestão do império, mantendo, assim, a vida política e a fortuna da aristocracia senatorial. Promoveu a ascensão e o enriquecimento de alguns equestres, já que com a estabilidade promovida pelo governo de Otaviano o comércio se desenvolveu e os cavaleiros lucraram com isso; os equestres também assumiram importantes cargos na administração do governo.

Otaviano mostra-se como o restaurador da paz, após longo período de guerra civil e ainda coloca-se como respeitador das tradições e das instituições romanas, diferente de seu adversário político, Marco Antônio, que havia se aproximado de um regime monárquico em seu envolvimento com a rainha do Egito. O imperador também promoveu diversos jogos e distribuições de trigo, realizou várias obras públicas, restaurações e construções de edifícios e estradas pelo território romano. Esse programa de construções e restauros,

\footnotetext{
${ }^{53}$ Conforme trechos de Suetônio expostos nas páginas 37-38 deste trabalho. Já sobre o reconhecimento do filho nascido após o divórcio. BARRETT, Anthony A. (2002). op. cit., p. 1923. HUNTSMAN, Eric D. AncSoc, p. 145-149. GRUBBS, Judith Evans. op. cit., p. 198-199.

${ }^{54}$ O tribuno da plebe Marco Lívio Druso citado anteriormente na página 23.

${ }^{55}$ BARRETT, Anthony A. (2002). op. cit., p. 22.
} 
que ele promoveu especialmente na cidade de Roma, demonstrava sua conexão com a cidade. O programa urbano era parte de um programa maior de Augusto que envolvia questões sociais, culturais, religiosas e políticas e estas se completavam e reforçavam ainda mais o significado de cada uma ${ }^{56}$.

Todas as atitudes de Augusto com os cidadãos romanos e seus aliados foram destacadas por meio de intensa propaganda e sua família fez parte desta, em última instância, suas ações foram relembradas em um texto de autoria própria, as Res Gestae. Foram erguidas estátuas suas e de seus familiares por todo o império, estas representações não apenas destacavam sua família, mas destacavam Roma, vinculando ambas e tornando a propaganda não apenas uma propaganda pessoal como também uma propaganda de Roma ${ }^{57}$; as crianças da família também foram incluídas nesse processo, elas figuraram nos triunfos e também nas representações artísticas; generosas doações de Augusto e das mulheres da domus Augusta ajudariam a população ou incentivariam a produção cultural romana; além da participação das mulheres em ritos religiosos próprios a elas e construções e reformas de templos realizados por vários integrantes da família. Estas ações faziam parte da propaganda augustana e garantiram também que os nomes de seus familiares fossem difundidos. Em 2 a.C. Augusto recebe o título de "Pai da Pátria", pátria essa que ele valorizou em seus programas e fez sua causa ao se colocar como respeitador dos valores romanos e em seu combate contra Marco Antônio. Percorrer a cidade de Roma era verificar por meio das construções os feitos de Augusto; ele tinha dado a Roma estabilidade duradoura incorporada em seu Mausoléu, paz e prosperidade mostradas na Ara Pacis e sucesso militar representado pelo obelisco egípcio e somado a isso representações de Augusto e sua família nos monumentos e em estátuas dispostas por toda a cidade. A propaganda augustana era difundida especialmente na cidade de Roma e na vida de seus habitantes. ${ }^{58}$

\footnotetext{
${ }^{56}$ FAVRO, Diane. Making Rome A World City. IN: GALINSKY, Karl (ed.). The Cambridge Companion to The Age of Augustus. New York: Cambridge University Press, 2005, p. 258260. EDER, Walter. op. cit., p. 28.

${ }^{57}$ EDER, Walter. op. cit., p. 28-29. RAMSBY, Teresa R; SEVERY, Beth. Gender, Sex, and the Domestication of the Empire in Art of the Augustan Age. Arethusa, v. 40, n. 1, Winter 2007, p. 44.

${ }^{58}$ FAVRO, Diane. op. cit., p. 258-260. FRASCHETTI, A. Roma al femminile. Roma : Laterza, 1994, p.134. RAWSON, Beryl. Adult-Child Relationships in Roman Society. In: RAWSON, Beryl
} 
A união de Lívia com Otaviano foi importante para a ampliação da base de apoio dele, e até recebeu alguns comentários negativos ${ }^{59}$; entretanto 0 acontecimento de destaque desse período inicial é o casamento de Otávia e Marco Antônio. Nesse momento a figura de Lívia é menos tratada nas fontes primárias, todavia, as questões familiares de Otaviano garantem a ela suas primeiras honras - recebeu proteção contra insultos verbais e estátuas suas foram erguidas ${ }^{60}$.

Otávia casou-se com Marco Antônio num claro acordo político em 40 a.C.; como naquela época estava recém viúva de Caio Cláudio Marcelo, foi preciso uma autorização senatorial para a realização dessa união, prazo que deveria ser aguardado para nascimento de possíveis filhos póstumos. Realizado o matrimônio, a família se mudou para Atenas após o nascimento da primeira filha, Antônia Maior ${ }^{61}$.

Um dos grandes destaques da ação da irmã foi sua mediação no Tratado de Tarento; este levou Marco Antônio a partir para o Oriente onde receberia tropas de Otaviano para combater os Partas, estendendo por mais cinco anos o triunvirato. Antônio enviou a esposa novamente para a Itália e partiu para o Oriente, onde se envolveu com a rainha Cleópatra; enquanto isso Otávia permanecia como uma esposa adequada, cuidando de seus filhos e dos filhos do casamento anterior dele com Fúlvia ${ }^{62}$.

Nesse período Otaviano concedeu à irmã e à esposa proteção legal contra insultos verbais (similar a dos tribunos da plebe); estátuas foram erguidas em suas honras e posteriormente ganharam o direito de gerir suas posses sem um tutor ${ }^{63}$ - Otávia em pleno direito por ter gerado cinco crianças. Qual seria a intenção de Otaviano com essas medidas e ainda, por que incluir

(ed.). Marriage, divorce, and children in Ancient Rome. Canberra, Oxford: Humanities research Centre, Clarendon Press, 1991, p. 21; 25; 27-28.

${ }^{59}$ Suet. Aug. 69, 1-2. Comentários sobre o casamento e o comportamento de Otaviano.

${ }^{60}$ FLORY, Marleen B. Livia and the History of Public Honorific Statues for Women in Rome. TAPhA, v. 123, 1993, p. 305.

${ }^{61}$ RAUBITSCHEK, Antony E. Octavia's Deification at Athenas. TAPhA, v.77, 1946, p. 146.

${ }^{62}$ Informações sobre o Tratado de Tarento e sobre a permanência de Otávia na Itália enquanto o marido estava com a rainha egípcia em Plut. Ant. 35; 54. Sobre permanecer cuidando de seus filhos e dos filhos do marido, de casamentos anteriores. SINGER, Mary White. Octavia's Mediation at Tarentum. CJ, v. 43, n. 3, p. 174-175. BARRETT, Anthony A. (2002). op. cit., p. 32. HUZAR, Eleanor G. Mark Antony: Marriages vs. Careers. CJ, v.81, n.2, $1985-1986$, p. 103-106. EDER, Walter. op. cit., p. 19. WIEAND, Helen E. The Position of Women in the Late Roman Republic. Part II. CJ, v. 12, n. 7 (Apr., 1917), p. 429-430. Suet. Aug. 13, 3.

${ }^{63}$ BARRETT, Anthony A. 2002, p. 136; 144. 
sua própria esposa nelas? Otávia vinha sendo tratada com desprezo pelo marido e ao retornar de Atenas o irmão pediu que ela morasse em uma casa própria; porém ela recusou sair da casa do marido e implorou ao irmão que se não possuísse motivos para iniciar uma guerra com Antônio, que ignorasse a forma como ele a tratava. Seria infame ter os dois homens iniciando uma guerra civil por tal motivo: um pela paixão de uma mulher e o outro pelos ressentimentos da outra. Barrett alega que Otaviano contava com esses maus tratos para denunciar a situação ao povo e ao Senado romano ${ }^{64}$. Ainda, com as honras também concedidas a Lívia, Otaviano deixava igual a posição das esposas dos triúnviros. Como destaca o trecho a seguir, mesmo casando-se com uma mulher de uma família relevante, Otaviano buscou estabelecer diversas outras conexões para estabilidade de seu poder, dentre estas estava o casamento de sua irmã Otávia com seu adversário político Marco Antônio:

É quase certo que Otávia, ao invés de Lívia, estivesse no topo do programa de Otaviano em 35, quando os privilégios especiais foram concedidos (...). Não que a proteção de Lívia seria sem valor político. Otaviano sabia que ele era vulnerável através dos ataques a sua mulher - os comentários insolentes sobre seu casamento eram um exemplo disto. Mas a principal razão para a inclusão de seu nome pode ter sido simplesmente para criar a imagem de que Otaviano estava mantendo iguais as posições das esposas dos triúnviros. ${ }^{65}$

Muito além de mediadora na relação com Marco Antônio, a irmã Otávia serviu a outro propósito: a formação de uma linha sucessória dentro da própria família ${ }^{66}$. A filha única de Otaviano, Júlia, casou-se com Marcelo, seu sobrinho, filho de Otávia. Este matrimônio deu inicio às uniões endogâmicas, ou seja, dentro da própria família. O excerto de Suetônio a seguir destaca essa união e percebe-se, ainda, a utilização do poder de paterfamilias de Augusto ao dissolver o casamento de sua sobrinha Marcela e utilizar-se do marido dela, Agripa, para uma nova união de sua filha Júlia, união esta que finalmente lhe daria herdeiros. Dos casamentos anteriores de Agripa temos sua filha Vipsânia, esposa do imperador Tibério que havia sido sua noiva desde crianças, cuja

\footnotetext{
${ }^{64}$ Plut. Ant. 54, 1. BARRETT, Anthony A. (2002). op. cit., p. 32.

${ }^{65}$ BARRETT, Anthony A. (2002). op. cit., p. 32.

${ }^{66}$ CORBIER, Mireille. Poder e parentesco. A família Júlio-Cláudia. Tradução de Consuelo Fontes Santiago. Classica, São Paulo, 5/6, 1992/1993, p. 177. MURRAY, Margaret. Royal Marriages and Matrilineal Descent. JRAI, v. 45, 1915, p. 317-325.
} 
separação ocorreu após a morte de seu pai para que o seu então esposo contraísse matrimônio com sua madrasta. Agripa esteve anteriormente ligado à família de Augusto em seu casamento com uma de suas sobrinhas, filhas de Otávia ${ }^{67}$.

Ele deu Júlia em casamento para Marcelo, filho de sua irmã Otávia e pouco mais que um garoto [na época], e após a morte dele para Marco Agripa, obrigando sua irmã a ceder o genro a ele; naquela época Agripa tinha como esposa uma das Marcelas e tinha filhos com ela. (Suet. Aug. 63, 1)

A não existência de filhos em seu matrimônio com Lívia, ou ainda o único filho do casal nascido morto, obrigou Otaviano a se valer das mulheres de sua família para obter filhos, por meio de adoção. Além do casamento de Júlia e Marcelo - a filha de Augusto e o filho de Otávia -, sua sobrinha Antônia Menor casou-se com o filho mais novo de Lívia, Druso. Por esse último matrimônio Lívia teve como netos, Germânico e Cláudio, que figurariam no jogo político - o primeiro em seu casamento que geraria Calígula e Agripina Menor (mãe de Nero) e o segundo assumindo o poder imperial mais tarde ${ }^{68}$. Os filhos de Germânico eram os bisnetos em comum de Lívia e Otaviano.

A morte do jovem Marcelo gerou alguns boatos que indicavam Lívia como responsável pelo seu óbito; entretanto, o motivo alegado para tal crime uma possível defesa de vantagens para os próprios filhos ${ }^{69}$ - não se faz cabível. O fato de Júlia ter se casado com Marco Agripa e gerado os dois jovens príncipes, Caio e Lúcio, que foram adotados por Augusto, faz com que os filhos de Lívia não tenham nenhuma vantagem política com a morte do jovem. Posteriormente a esse matrimônio, Augusto faz algumas visitas às províncias orientais e é certo que em muitas destas viagens foi acompanhado de Lívia; sabe-se disso por meio de um discurso feito no Senado pelo filho de Tibério Cláudio Druso, presente no trecho a seguir:

Druso acrescentou algumas frases sobre sua própria vida conjugal: - Príncipes não raramente tinham que visitar as partes mais remotas do império. Quantas vezes o divino

\footnotetext{
${ }^{67}$ Considera-se que Agripa tenha sido casado com Marcela Maior. CORBIER, Mireille (1992/1993). op. cit., p. 172-173.

${ }^{68}$ CORBIER, Mireille (1992/1993). Classica, p. 176-178. MURRAY, Margaret. JRAI, p. 317-321. MULLENS, H. G. The Women of the Caesars. G\&R, v. 11, n. 32 (Feb., 1942), p. 60.

${ }^{69}$ Dio Cas. Hist. 53, 33, 4. Vel. Hist. 2, 93, 1.
} 
Augusto viajou para o oeste e leste com Lívia em sua companhia? Ele próprio tinha feito uma excursão para a llíria; e, se houvesse um propósito para servir, ele estava preparado para ir para outras regiões - mas não sempre, sem uma pontada, se estivesse separado da esposa bem-amada que era a mãe de seus muitos filhos. (Tac. Ann. 3, 34, 11-13)

Lívia, pouco tempo depois, passa pela mesma situação que a cunhada e perde seu filho mais novo, Druso. Nesse momento a figura dela entra na cena pública definitivamente: a mãe sofrendo pela perda do filho tem uma atitude louvável durante todo o processo de transporte do corpo, funeral e nos eventos seguintes.

Durante o cumprimento de uma atividade militar na Germânia em 9 a.C., Nero Cláudio Druso sofre um acidente andando a cavalo e seu estado agravase com o passar dos dias. Essa situação causou tamanha consternação ao povo romano e mesmo aos inimigos, que acabaram por declarar uma trégua. Seu irmão, Tibério, tentou chegar até ele ainda vivo, encontrando-o em seus momentos finais; após o óbito acompanhou o corpo até o encontro com 0 padrasto e a mãe ${ }^{70}$.

Mesmo que a morte dele também tenha gerado boatos de assassinato por suas supostas intenções republicanas ${ }^{71}$, é necessário destacar que Augusto - que teria sido acusado de sua morte - mostrou extrema atenção para com o jovem. Efetuou elogios no Circo Máximo, escreveu um poema para ele e ainda uma prosa sobre sua vida, falando publicamente que esperava que seus filhos (adotivos) Lúcio e Caio seguissem os passos de Druso. Outro elogio foi feito por Tibério e as cinzas foram depositadas no Mausoléu de Augusto ${ }^{72}$.

Esse evento possibilitou que Lívia expusesse seus sentimentos publicamente; mesmo demonstrando muita dor em todo o processo ela permitiu-se conversar sobre o filho, até mesmo incentivando tal fato depositando imagens dele em lugares públicos e privados, conversando com filósofos, familiares e amigos sobre ele. Diferentemente da cunhada Otávia, que após a morte do jovem Marcelo permaneceu durante toda sua vida reclamando da perda de seu promissor filho ${ }^{73}$.

\footnotetext{
${ }^{70}$ Dio Cas. Hist. 55, 1-2. BARRETT, Anthony A. (2002). op. cit., p. 42-44.

${ }^{71}$ Tac. Ann. 2, 82, 3. Suet. Tib. 50, 1.

${ }^{72}$ Suet. Claud. 1, 5. Tac. Ann. 3, 5.

${ }^{73}$ BARRETT, Anthony A. (2002). op. cit., p. 40-44; 122.
} 
Devido à morte de seu filho, foi escrito para Lívia um poema comumente atribuído a Ovídio, porém tanto o autor como a data em que foi escrito não são conhecidos com certeza. Estima-se que a produção desse texto tenha sido durante o principado de Tibério, sendo o poema conhecido como Consolatio ad Liviam $^{74}$. Esta honra confirma que Lívia e suas atitudes eram observadas com interesse pelos romanos; o papel da esposa do imperador destaca-se nesse ponto. Mesmo não tendo uma vida pública - pensando em vida política - as mulheres dos imperadores estavam ao seu lado em festas, em eventos públicos e eram observadas, como destaca o trecho de Molly Pryzwansky:

Mulheres imperiais são pessoas privadas no sentido de que elas não ocupam cargos próprios, mas a Consolatio deixa claro que viviam sob o olhar público e que suas ações poderiam impactar os cidadãos romanos diretamente ${ }^{75}$.

Dion nota que o Senado (e em sua própria época, o imperador) tinha o direito de conceder este privilégio àqueles cuja falta de ter três filhos foi involuntária. Esse princípio seria aplicável no caso de Lívia. Ela havia de fato dado à luz três vezes, mas o filho que ela compartilhava com Augusto era prematuro e natimorto e, portanto, legalmente não se qualifica ${ }^{76}$.

Pela perda de Lívia o Senado votou erguer estátuas para ela e garantiu o ius (trium) liberorum mesmo sem os três filhos necessários para essa honra 77; como destaca o trecho de Barrett, poderia ser concedido se também considerado o filho natimorto do casal. Dessa forma contando os filhos do casamento com Tibério Cláudio Nero, Tibério e Druso, Lívia pode receber esse privilégio de poder gerir seus bens sem a necessidade de um tutor.

Seu comportamento na época do falecimento do filho foi tido como correto para a ocasião e elogiado ${ }^{78}$. Lívia permaneceu durante os primeiros anos de seu matrimônio fora do foco dos comentários políticos; entretanto este

\footnotetext{
74 PRYZWANSKY, Molly M. Feminine Imperial Ideals in the Caesares of Suetonius. Dissertation (Doctor of Philosophy) - Department of Classical Studies - Graduate School of Duke University, 2008, p. 24-25. JENKINS, Thomas E. Livia the Princeps Gender and Ideology in the Consolatio ad Liviam. Helios, v. 36, n. 1, Spring 2009, p. 1.

${ }_{76}^{75}$ PRYZWANSKY, Molly M. op.cit., p. 26.

${ }^{76}$ BARRETT, Anthony A. (2002). op. cit., p. 46.

${ }^{77}$ DIXON, Suzanne. The Roman Mother. London: Routledge, 1990, p. 89-90. FLORY, Marleen B. op. cit., p. 306. GRUBBS, Judith Evans. op. cit., p. 37-43.

${ }^{78}$ BARRETT, Anthony A. (2002). op. cit., p. 44; 124.
} 
comportamento iniciou a série de elogios sobre sua figura, como esposa e como mãe ${ }^{79}$, nesse primeiro momento.

\title{
2.3 A relação familiar de Lívia com Augusto e o poder
}

A posição de Lívia durante seu casamento com Augusto pode ser evidenciada por intermédio da descrição do matrimônio em algumas passagens de Suetônio, uma na biografia de Augusto, outra na de Tibério e ainda na de Cláudio.

\begin{abstract}
Pouco depois, casou-se com Escribônia, que havia sido casada anteriormente com dois ex-cônsules e possuía filhos de um deles. Também se divorciou dela, "incapaz de tolerar a perversidade de sua moral", como ele próprio escreveu, e imediatamente tomou Lívia Drusila de seu marido Tibério Nero; embora ela estivesse grávida na época, ele a amou e estimou até o fim sem rivais. (Suet. Aug. 62, 2)
\end{abstract}

No primeiro trecho, presente na biografia de Augusto, Suetônio mostra que Otaviano tomou para si Lívia, mesmo que grávida de outro homem e a ela esteve sentimentalmente ligado até sua morte, amenizando a força da palavra tomar ${ }^{80}$. A passagem começa com a descrição de que o próprio Otaviano decidiu pelo divórcio e não foi seduzido, se deixado levar por Lívia, ou ainda cometido adultério com ela, como alguns boatos questionavam.

Otaviano ainda havia terminado um casamento com uma mulher que anteriormente esteve casada com outros políticos romanos; o destaque dessa informação no trecho é relevante se pensarmos que as mulheres estabelecem elos políticos em seus matrimônios. Nesse excerto Lívia assume apenas o papel de esposa, uma mulher adequada para Augusto, submetida à sua autoridade desde o começo do casamento ${ }^{81}$.

Já na segunda passagem o autor apresenta a mesma história, porém Lívia é entregue a ele depois do pedido feito ao seu marido por Otaviano.

\footnotetext{
${ }^{79}$ BARRETT, Anthony A. (2002). op. cit., p. 42-44. FLORY, Marleen B. op.cit., p. 304-306. PRYZWANSKY, Molly M. op. cit., p. 35.

${ }^{80}$ PRYZWANSKY, Molly M. op. cit., p. 118.

${ }^{81}$ PRYZWANSKY, Molly M. op. cit., p. 225.
} 
[Tibério Cláudio Nero] irritou-se, no entanto, porque ele não foi recebido de imediato em uma audiência com Sexto Pompeu, sendo negado o uso dos fasces; atravessou para a Acaia e se juntou a Marco Antônio. Com ele, logo retornou a Roma, em concordância com a paz geral e entregou a Augusto, a seu pedido, sua esposa Lívia Drusila; que estava grávida na época e já havia the dado um filho. Ele morreu pouco depois, subsistindo por ambos os filhos, Tibério Nero e Druso Nero. (Suet. Tib. 4, 3)

Como pode ser observado, na biografia de Tibério esse matrimônio ocorre de forma diferente: Lívia é entregue a Augusto por Tibério Cláudio Nero. Ela não assume um papel de submissão imediata ao cônjuge. O foco da narrativa é o pai do futuro imperador e a descrição de que ambos os filhos nascidos eram reconhecidamente prole dele. Nessa biografia, Lívia assume o papel de mãe de Tibério.

É importante destacar tais mudanças, pois a figura de Lívia é vista diferente em cada momento. Otaviano toma uma esposa e essa permanece sob sua autoridade durante todo o matrimônio, e é dessa forma que ela é representada ao longo do texto referente a Augusto.

O pai de Cláudio César, Druso, que a princípio tinha o prenome Décimo e depois o de Nero, nasceu de Lívia três meses após seu casamento com Augusto (pois ela esperava um filho na época) e havia a suspeita de que ele tinha sido gerado por seu padrasto em relação adúltera. (Suet. Claud. 1,1)

Na biografia de Cláudio é necessário retomar esse evento, pois ocorreu durante a gravidez de Druso, pai do futuro imperador Tibério Cláudio Druso. A figura de Lívia era agora a de avó, sendo esse papel mais bem tratado nesse texto do que em qualquer outra das Vidas. Como destaca o trecho a seguir havia, ainda, a tentativa de que com o boato de adultério, Cláudio fosse vinculado a Augusto. Por isso, tomar ou entregar Lívia nesse matrimônio já não faria tanta diferença, apenas a paternidade de Druso é questionada.

Esta é uma tática bem-sucedida da Vida de Cláudio, um imperador "surpresa" que nunca esteve na linha direta de sucessão. Ao ligar Cláudio estreitamente à Lívia e Augusto desde o início da biografia, Suetônio será melhor capaz de explicar como Cláudio subiu ao poder. ${ }^{82}$

\footnotetext{
${ }^{82}$ PRYZWANSKY, Molly M. op.cit., p. 123.
} 
Outra fonte que também descreve esse evento é a obra "Anais" de Tácito.

\begin{abstract}
Suas aventuras domésticas não foram poupadas; a tomada da mulher de Nero e os questionamentos farsescos para os Pontífices, se com uma criança concebida e ainda não nascida ela poderia casar oficialmente; os deboches de Védio Pólio; e, por fim, Lívia - como mãe, uma praga para a República, como madrasta, uma maldição para a casa dos Césares. Ele havia deixado pouco espaço para o culto do divino, quando exigiu ele mesmo ser adorado nos templos, em imagens, por flâmines e por sacerdotes. (Tac. Ann. 1, 10, 4-5)
\end{abstract}

Nesse trecho novamente há Otaviano "tomando" Lívia de seu marido. Ainda se tem uma cena mais completa, na qual o futuro imperador questiona os Pontífices sobre a possibilidade de realizar o casamento, mesmo Lívia estando grávida. Após divórcios e viuvez as mulheres romanas deveriam aguardar um período ${ }^{83}$ para realizarem novos casamentos, entretanto, dada a paternidade da criança ser previamente assumida por Tibério Cláudio Nero, poderiam não aguardar esse período. O autor considera, assim, essa consulta realizada falsa e mostra clara preocupação com a gravidez dela; Suetônio omite essa situação em todas suas descrições evitando assim questionamentos sobre a impropriedade da rapidez dessa união ${ }^{84}$.

Outro questionamento é feito sobre a permissão que Tibério Cláudio Nero teria dado a Augusto. Seria esta em detrimento do tipo de casamento entre Lívia e Tibério? E dessa forma Augusto teria que "pedir" Lívia ${ }^{85}$, assim como destacado no trecho da biografia de Tibério. Existem dois tipos básicos de matrimônio na Roma Antiga, o matrimônio cum manu e o matrimônio sine manu. O primeiro tipo retira a esposa da patria potestas (tutela do pai) e coloca-a sobre a potestas do marido, ou do sogro caso ainda vivo. Ela passava a ocupar juridicamente a posição de uma filha, igualando-se aos próprios filhos na questão sucessória. O casamento sine manu mantém a mulher sob a

\footnotetext{
${ }^{83}$ Era um período de 10 meses em que se aguardava o nascimento de possíveis filhos, assim a paternidade seria atribuída ao ex-marido vivo ou falecido. GRUBBS, Judith Evans. op. cit., p. 220-223. GARDNER, Jane F. op. cit., p. 52.

${ }^{84}$ PRYZWANSKY, Molly M. op. cit., p. 118.

${ }^{85}$ FLORY, Marleen B. Abducta Neroni uxor: The Historiographical Tradition on the Marriage of Octavian and Livia. TAPhA, v. 118, 1988, p. 346-348.
} 
potestas do pai, que poderia intervir para protegê-la e ainda a mantém com vocação sucessória ${ }^{86}$.

O divórcio era possível no casamento sine manu pela iniciativa de qualquer um dos cônjuges; no outro caso, o marido poderia repudiar a esposa. Por fim, uma mulher casada sob o sistema sine manu tende a uma maior independência, principalmente após a morte do paterfamilias. O uso dessa forma de casamento, ainda na época republicana, tornou-se muito frequente. Considera-se que o paterfamilias poderia pedir o divórcio dos filhos; conhecemos diversos casos desta possível intervenção com filhas e ainda conhecemos o caso de Tibério e seu casamento com Vipsânia, no qual Augusto requereu seu divórcio da mesma para casá-lo com sua filha Júlia ${ }^{87}$. 0 pai de Lívia faleceu antes de seu primeiro matrimônio e não temos referências sobre um possível tutor ${ }^{88}$.

Não se pode afirmar qual era a forma de casamento utilizada por Lívia e Tibério Cláudio Nero; se ela estaria sob a tutela de seu marido e por isso Augusto necessitava "pedir" a ele a esposa. Nem mesmo podemos considerar que suas posses permaneceram mesmo após o divórcio, tendo em vista que a família havia sido proscrita - como seria o caso em um casamento sine manu. Ainda que Suetônio estivesse se referindo a forma de casamento de Lívia, por que a mudança no trato do matrimônio ocorre em três de suas biografias? Acreditamos que a forma como ela é tratada nestes textos difere de um para o outro, e essa sutil mudança na descrição da união parece mostrar o tom utilizado ao longo de cada biografia. Destacamos também que o próprio Tibério Cláudio Nero esteve vinculado à história de Roma, com o divórcio e a nova

\footnotetext{
${ }^{86}$ CASTRO, Flávia Lages de. Mulheres Romanas. Rio de Janeiro: Lumen Juris, 2004, p. $13-$ 19. DUBY, G. \& PERROT, M. (Dir.). op. cit., p. 141-145; 183-185. GOUREVITCH, Danielle; RAEPSAET-CHARLIER, Marie-Thérèse. A vida quotidiana: da mulher na Roma Antiga. Lisboa: Livros do Brasil, 2006, 66-73. GILISSEN, John. Introdução Histórica ao Direito. Lisboa: Fundação Calouste Gulbenkian, 2003, p. 565; 584. HERSCH, Karen K. The Roman Wedding: Ritual and meaning in Antiquity. New York: Cambridge University Press, 2012, p. 2327. GRUBBS, Judith Evans. op. cit., p. 195-197. CORBIER, Mirelle. Divorce and adoption as familial strategies. In: RAWSON, Beryl (ed.). Marriage, divorce, and children in Ancient Rome. Canberra, Oxford: Humanities research Centre, Clarendon Press, 1991, p. 51. TREGGIARI, Susan. Divorce Roman Style: Ease and frequency. In: RAWSON, Beryl (ed.). (1991), op.cit., p. 33-44. GARDNER, Jane F. op. cit., p. 44-50.

87 CASTRO, Flávia Lages de. op.cit., loc.cit. DUBY, G. \& PERROT (Dir.). op.cit., loc.cit. GOUREVITCH, Danielle; RAEPSAET-CHARLIER, Marie-Thérèse. op.cit., loc.cit. GILISSEN, John. op.cit., loc.cit. GRUBBS, Judith Evans. op. cit., p. loc.cit. CORBIER, Mirelle. (1991). op.cit., loc.cit. TREGGIARI, Susan. (1991), op.cit., loc.cit. GARDNER, Jane F. op. cit., loc.cit. CORBIER, Mireille (1992/1993). Classica, p. 173.

${ }^{88}$ HUNTSMAN, Eric D. AncSoc, p. 140.
} 
união de Lívia. Além de deixar seus filhos sob a tutela de Augusto, seus descendentes tornaram-se os quatro imperadores da dinastia Júlio-Cláudia ${ }^{89}$.

Que ele [Augusto] foi dado ao adultério nem mesmo seus amigos negam. Embora seja verdade que os desculpem como cometidos não a partir da paixão, mas sim da política, o mais prontamente para obter 0 controle de projetos de seus adversários por intermédio das mulheres das suas famílias. Marco Antônio o acusou, além de seu casamento apressado com Lívia, de tomar a esposa de um ex-cônsul da sala de jantar de seu marido diante de seus olhos para um quarto, e trazê-la de volta à mesa com os cabelos em desordem e suas orelhas incandescentes. Escribônia se divorciou porque exprimiu seu ressentimento muito livremente sobre a influência excessiva de uma rival; que seus amigos atuavam como seus alcoviteiros, despojavam e inspecionavam matronas e meninas núbeis, como Torânio o comerciante de escravos que os colocava à venda. Antônio também escreveu para Augusto, ele próprio, nos seguintes termos familiares, quando ainda não tinha totalmente rompido com ele, em privado ou publicamente: "O que fez essa mudança em você? Porque eu deito com a rainha? Ela é minha esposa. Estou apenas começando isso, ou foi há nove anos? O que então vós - você se deitou com Drusila? Boa sorte para você, se quando ler esta carta não tiver sido com Tértula ou Terentina ou Rúfila ou Sílvia Ticênia, ou todas elas. Faz diferença onde ou com quem você tem seu prazer?" (Suet. Aug. 69,1-2)

A primeira parte deste trecho de Suetônio expõe claramente o uso de relações amorosas com mulheres para obtenção de vantagens políticas, no caso para descobrir os projetos dos adversários. Esta passagem já evidência que as mulheres estavam vinculadas indiretamente no jogo político. Suetônio ainda exprime os comentários negativos provenientes de Marco Antônio ao seu casamento e ao seu comportamento de forma geral; este excerto se segue de descrições de uma festa, na qual Augusto teria se colocado representando Apolo; cenas de jantares e jogos, onde ele teria até mesmo jogado valor mais alto que o habitual. Destaca-se a seguir a possível conivência de Lívia com traições do marido, levando até ele mulheres para prestarem serviços sexuais ${ }^{90}$. Entretanto tais comentários sobre seu comportamento, independente de sua veracidade, são amenizados em suas próprias descrições e fazem parte das

\footnotetext{
${ }^{89}$ CORBIER, Mirelle. (1991). op.cit., p. 59-60.

${ }^{90}$ Suet. Aug. $70-71$.
} 
descrições dos vícios dos Césares presentes nas biografias de Suetônio ${ }^{91}$. Confirmam, ainda, a imagem de esposa submetida ao marido presente nesse texto:

Ele não pode eliminar as acusações de lascívia e dizem que, mesmo em seus últimos anos gostava de deflorar virgens, que foram reunidas para ele de todos os cantos, até mesmo por sua própria esposa. (Suet. Aug. 71, 1)

A partir dessas ideias, que têm início na descrição do casamento na biografia de Augusto, a autora Pryzwansky considera que Lívia é representada como uma "boa" esposa ${ }^{92}$, no sentido de nunca sobrepor-se ao seu marido ou ter atitudes de interferência em âmbitos masculinos. A partir da descrição de que Lívia foi tomada por Augusto ela é representada como uma mulher submetida à autoridade do esposo ${ }^{93}$. Lívia é uma das poucas mulheres que é destacada por suas atitudes sem acusações de cruzar a linha entre os âmbitos femininos e masculinos; também difere nas acusações sexuais, pois ela não é acusada de se valer de amantes para atingir qualquer objetivo. Lívia é influente mesmo não se sobrepondo ao marido; Lívia é influente mesmo sem amantes.

Todos os questionamentos sobre seu casamento contaram para sua ausência da vida pública e das fontes nos primeiros anos da união ${ }^{94}$, retornando brevemente nas honras também cedidas à cunhada Otávia; entretanto é sabido que Lívia acompanhou Augusto em uma série de viagens ${ }^{95}$. Durante estas viagens, a matrona pode fazer varias amizades e desenvolver certas habilidades diplomáticas que mais tarde Ihe foram de grande valia; como durante o principado de Tibério, a matrona ajudando o filho na negociação com o rei Arquelau da Capadócia ${ }^{96}$; fez também amizade com Salomé da Judéia, a qual visitou em sua passagem pela Síria com Augusto. Outra passagem que

\footnotetext{
${ }^{91}$ CIZEK, Eugen. Structures et idéologie dans "Les vies des douze Césars" de Suétone. Bucuresti : Editura Academiei ; Paris : Les Belles lettres, 1977, p. 136.

${ }_{92}$ PRYZWANSKY, Molly M. op. cit., p. 50 . Em concordância, também, com a qualificação dos governantes em melhores e piores que pode ser notada ao se opor vícios e virtudes, presente em CIZEK, Eugen. op. cit., p. 154-155. A tese de Pryzwansky mostra que as mulheres que interferem na vida dos filhos (especialmente em questões política) ou têm comportamentos sexualmente reprováveis aparecem durante as descrições das Vidas de forma negativa. Uma boa esposa e uma boa mãe não interferem na vida dos homens da família.

${ }^{93}$ Conforme exposto nas páginas 37-38 deste trabalho.

${ }^{94}$ BARRETT, Anthony A. (2002). op. cit., p. 28.

${ }^{95}$ Tac. Ann. 3, 34, 12.

${ }^{96}$ Tac. Ann. 2, 42. Conforme exposto na página 66 deste trabalho.
} 
relevante foi a liberdade concedida à llha de Samos no período entre 20 e 19 a.C.; Dion informa que por vezes o casal passava um período na ilha, geralmente durante invernos. Segundo Barrett, Lívia havia sido a responsável por essa libertação da ilha devido a alguns pedidos feitos ao marido, entretanto Augusto não tinha concedido das outras vezes. A liberdade concedida à ilha por Augusto também é comentada por Dion, porém Lívia não é citada ${ }^{97}$.

Após as mortes de Agripa e Otávia, em 13 e 12 a.C. respectivamente, o filho mais velho de Lívia passa, também, a fazer parte da rede de matrimônios que vinculava as famílias: Tibério casa-se com Júlia, a filha de Augusto; e Druso nessa época já estava casado com Antônia Menor, a filha de Otávia ${ }^{98}$. A existência dos filhos do casamento anterior de Júlia afastava nesse momento qualquer possibilidade sucessória de Tibério, pois os jovens haviam sido adotados por Augusto.

O banimento da filha de Augusto por seu comportamento extravagante e seus adultérios traz à tona outra característica de Lívia, a piedade. Lívia permaneceu ajudando Júlia e posteriormente a filha desta, Júlia II, no exílio de ambas ${ }^{99}$. É sabido que Augusto a repudiou em nome de Tibério, pois este se encontrava em Rodes por desgosto com sua esposa e com essa situação ${ }^{100}$. Esse afastamento de Tibério também causou profundo descontentamento em Augusto; Lívia, nesse momento, tenta interceder pelo filho para conseguir que o marido permitisse seu retorno para a cidade de Roma ${ }^{101}$.

Esta situação leva a pensar o quanto Lívia teria de influência nas decisões do marido, tendo em vista que a tentativa de interferência na relação entre ele e o filho durou de 6 a.C. até 2 d.C. após o banimento de Júlia. Alguns dos pedidos feitos por ela foram atendidos por Augusto, como a libertação da ilha de Samos anteriormente citado. Entretanto, é necessário destacar que a figura dela aparece em Suetônio, sobretudo nas biografias de Augusto e de Tibério, de formas diferentes. Destacam-se alguns trechos presentes na biografia de Augusto:

\footnotetext{
${ }^{97}$ Dio Cas. Hist. 54, 7, 4; 9, 7. BARRETT, Anthony A. (2002). op. cit., p. 36-38.

${ }^{98}$ BARRETT, Anthony A. (2002). op. cit., p. 40. CORBIER, Mireille (1992/1993). Classica, p. 177-178.

${ }^{99}$ Informação sobre Lívia ajudando Júlia I no exílio. Tac. Ann. 4, 71, 6. Ela também ajudou Júlia II, que também havia sido exilada. BARRETT, Anthony A. (2002). op. cit., p. 51.

${ }_{100}$ PRYZWANSKY, Molly M. op. cit., p. 211. BARRETT, Anthony A. (2002). op. cit., p. 51-57.

101 Suet. Tib. 12, 1. Ponto melhor abordado na página 55 desse trabalho.
} 
Quando Tibério pediu a cidadania para um de seus dependentes grego, Augusto escreveu em resposta que não iria concedê-la a menos que o homem aparecesse em pessoa e o convencesse que ele tinha motivos suficientes para 0 pedido; e quando Lívia solicitou para um gaulês de uma província tributada, ele recusou, oferecendo ao invés a isenção de tributo, declarando que preferia de bom grado sofrer a perda de suas riquezas privadas do que a prostituição da honra de cidadania romana. (Suet. Aug. 40, 3)

Mesmo suas conversas com [quaisquer] indivíduos e o mais importante desses, com sua própria esposa Lívia, ele sempre escreveu e leu a partir de um bloco de notas, por medo de dizer muito ou pouco se falasse de improviso. (Suet. Aug. 84, 2)

Nesses trechos é possível notar que, sobretudo, no que concerne ao direito de cidadania, Augusto, em sua postura de restaurador da República e dos valores morais antigos ${ }^{102}$, não desrespeitava o direito primordial dos homens romanos, a cidadania plena. O imperador, mesmo promovendo mudanças, buscou agir de forma gradativa durante seu governo; ele não aceitou todas as honras e títulos que Ihe foram oferecidos de imediato. Augusto exerceu seu poder sem desrespeitar as instituições romanas; mesmo sendo possuidor de uma autoridade maior do que a de todos, ele respeitou as magistraturas romanas. Dessa forma o imperador não iria fornecer a cidadania romana para diversas pessoas ou ainda de forma desmedida, pois isso causaria uma comoção desnecessária em torno de sua figura. Entretanto, o pedido de sua mulher foi parcialmente aceito, fornecendo certo benefício ao gaulês que utilizou da intermediação dela para requerer a isenção dos tributos.

A posição de Lívia como cônjuge do imperador fazia dela uma ótima opção para pedidos de intermediação em qualquer situação; é sabido que em muitos outros casos ela e Augusto conversaram - como destacou o trecho de Suetônio - e seus conselhos foram muito apreciados por ele ${ }^{103}$, tornando-a de extrema relevância. Aproximar-se de uma dessas mulheres era poder ter um acesso mais fácil ao governante, não somente Lívia como também as outras mulheres próximas dos imperadores, irmãs, mães e filhas. Sob Augusto destaca-se também Otávia, que em suas atividades de patrocínio intelectual

\footnotetext{
102 Conforme exposto na página 25 deste trabalho.

103 BARRETT, Anthony A. (2002). op. cit., p. 131-132.
} 
permitiu ao arquiteto Vitrúvio ser apresentado ao governante e assim se tornar responsável por algumas obras do período ${ }^{104}$. Das atividades patronais de Lívia se tem Ário Dídimo, que além de importante papel durante a morte de Druso, auxiliando a matrona, foi conselheiro pessoal do imperador ${ }^{105}$. Como mostrou o trecho de Suetônio citado anteriormente, as mulheres fazem pontes importantes. Por meio delas pode-se chegar próximo a um político, intencionando tanto apoio, amizade, benefícios ou parcerias por meio de casamentos; como também descobrir intenções políticas ou projetos de adversários. Um papel político indireto, porém de extrema importância.

"Conversei com Tibério ${ }^{106}$, minha querida Lívia, como você pediu. Em relação ao que deve ser feito com o seu neto Tibério nos jogos de Marte, estamos ambos concordando que é preciso decidir de uma vez por todas qual é o plano que estamos adotando em seu caso. Para isso ele deve parecer, por assim dizer, preparado; quais razões para duvidar que ele deva ter avançado nos mesmos graus e séries pelas quais seu irmão passou? Mas, se percebemos que ele é defeituoso na solidez do corpo e da mente, não podemos fornecer os meios de ridicularizar tanto ele, quanto nós para um público que está acostumado a zombar e ridicularizar tais coisas. Certamente estaremos para sempre preocupados se deliberamos sobre todas as ocasiões separadamente e não fizermos a nossa mente antecipadamente, quer pensemos que ele possa exercer cargos públicos ou não. No entanto, com relação aos assuntos sobre os quais você pediu meu conselho atual, eu não me oponho aos seus encargos do banquete dos sacerdotes nos jogos de Marte, se ele vai se permitir ser assessorado por um parente, filho de Silvano, de modo a não fazer nada para tornar-se visível ou ridículo. Que ele deva ver os jogos no Circo dos assentos imperiais não é de minha aprovação, pois ele será notado se exposto à plena vista na frente do auditório. Sou contra a sua ida para o Monte Albano ou que fique em Roma nas festas Latinas; por que torná-lo prefeito da cidade, se ele é capaz de seguir seu irmão até o Monte? Você tem a minha opinião, minha querida Lívia, sabe que desejo que algo deva ser decidido de uma vez por todas sobre toda a matéria, para nos salvar de constantemente oscilar entre esperança e medo. Além disso, você pode, se quiser, dar parte da minha carta para nossa parenta Antônia também ler"; "Eu certamente convidarei o jovem Tibério para jantar todos os dias durante a sua ausência, para impedi-lo de jantar sozinho com seus amigos Sulpício e Atenodoro. Eu desejo que ele escolha mais

104 BARRETT, Anthony A. (2002). op. cit., p. 199. HEMELRIJK, Emily Ann. Matrona docta: educated women in the Roman élite from Cornelia to Julia Domna. London : Routledge, p. 104-105.

${ }^{105}$ BARRETT, Anthony A. (2002). op. cit., p. 108. HEMELRIJK, Emily Ann. op. cit., p. 36.

${ }^{106}$ Refere-se ao futuro imperador Cláudio (Tibério Cláudio Druso). 
cuidadosamente e de forma menos aérea alguém para imitar os movimentos de conduta e do andar. O pobre rapaz não tem sorte; pois em questões importantes, nas quais sua mente não se desvia, a nobreza de seu caráter é aparentemente suficiente"; "Teu neto, Tibério, encantou-me com suas declamações, minha querida Lívia, e que eu morra se isso não me surpreende. Como alguém que é tão pouco claro em sua conversa pode falar com nitidez e propriedade quando declama, custa-me crer em tal coisa." (Suet. Claud. 4, 1-6)

Estes trechos da biografia de Cláudio mostram, também, outro ponto da relação entre Augusto e Lívia, e entre a família de forma geral. Primeiro, notase que Lívia e Augusto costumavam trocar correspondência - algumas em grego denotando conhecimento dela desse idioma ${ }^{107}$-, prática comum entre as mulheres romanas e seus esposos; tendo em vista que os homens exerciam alguns cargos fora da cidade de Roma, as mulheres não acompanhavam os maridos, e era nesse caso, dever da esposa manter o cônjuge informado dos acontecimentos na cidade ${ }^{108}$. Entretanto, é de grande destaque a preocupação com os jovens da domus Augusta de uma forma geral, não somente os filhos dos casamentos - do matrimônio de Augusto com Escribônia e do matrimônio de Lívia após a morte do primeiro marido Tibério Cláudio Nero - permaneceram aos cuidados da matrona.

Nestes excertos, Lívia e seu marido conversam sobre seu neto; no primeiro trecho o assunto tem importância política: incluir o neto na vida pública é uma forma de se valer da relevância de sua posição - esposa do imperador para colocar um parente em foco para a sociedade romana. No trecho, destaca-se, também, Augusto questionando o modelo de comportamento de Cláudio; devido o falecimento de seu pai Druso, outro homem deveria ser o exemplo moral desse jovem.

Dentre as crianças, ou jovens, que permaneceram sob os cuidados de Lívia estão em primeiro lugar a filha de Augusto, Júlia; depois seus próprios filhos voltam a morar com ela; mais tarde, os filhos adotivos de Augusto, Caio e Lúcio; durante os períodos de campanha, Cláudio e Germânico permaneceram aos cuidados da avó, e após a morte de Druso, sua esposa Antônia decide não mais se casar e permanece junto a Lívia até a morte desta; depois da morte de Germânico, Calígula e pelo menos duas de suas irmãs foram criados por ela;

\footnotetext{
107 BARRETT, Anthony A. (2002). op. cit., p. 106.

108 HEMELRIJK, Emily Ann. 2002. op. cit., p. 188-189.
} 
supõem-se que antes de seu primeiro casamento, Agripina Menor também tenha morado com a matrona ${ }^{109}$.

Muitos desses jovens viveram juntos e foram educados juntos, tendo em vista que quando se contratava professores particulares meninas e meninos eram educados juntos ${ }^{110}$. Como pode ser observado no trecho a seguir da pesquisadora Hemelrijk, a presença constante de professores na casa também tinha relação com as atividades de patronato, muitas vezes exercidos pelas mulheres:

Como professores particulares eles tinham contato próximo com as mulheres da família imperial, que supervisionavam a educação de suas próprias crianças e às vezes de muitas outras crianças da família imperial. ${ }^{111}$

(...) Ele [Augusto] nunca deixou de tratar a todos eles considerando-os como parte integrante do império; regularmente nomeava um tutor para os que eram jovens demais para governar ou cujas mentes foram afetadas, até que crescessem ou se recuperassem; e fez vir os filhos de muitos deles e os educou junto de seus próprios. (Suet. Aug. 48)

De acordo com esta passagem de Suetônio, estes jovens não eram apenas educados juntos de primos, irmãos de criação, como também eram educados juntos a alguns herdeiros de reinos que se relacionavam com Roma; isto possibilitava contatos com futuros governantes; facilitando recebimento de heranças e contatos diplomáticos, tanto dos jovens educados em conjunto quanto das matronas responsáveis. Especialmente Lívia vivencia essa situação, pois é a mulher da família imperial do período Júlio-Claudiano que tem sob seus cuidados o maior número de crianças e jovens.

O uso da família de Augusto como parte da política propagandista - que difundiu seus feitos e sua postura de respeitador da moral e das tradições romanas - foi decisivo; e Lívia, em seu papel de esposa do imperador, cumpriu

\footnotetext{
${ }^{109}$ Calígula viveu com Lívia após o banimento de sua mãe. Suet. Calig. 10, 1. Outras fontes informam sobre os jovens da família e a permanência deles junto de Lívia, considerando questões jurídicas e a ausência dos pais por motivos diversos. BARRETT, Anthony A. (2002). op. cit., p. 56; 78; 99; 129. HEMELRIJK, Emily Ann op.cit., passim. Tem-se ainda a possibilidade de Agripina Menor ter morado com Lívia antes do primeiro casamento. BARRETT, Anthony A. Agrippina: sex, power, and politics in the Early Empire. London: Routledge, 1996, p.37.

${ }_{110}$ CORBIER, Mireille (1992/1993). Classica, p. 191-192. HEMELRIJK, Emily Ann. op. cit., p.20-58.

${ }^{111}$ HEMELRIJK, Emily Ann. op. cit., p. 104.
} 
bem o papel materno ${ }^{112}$ - mesmo não tendo dado nenhum filho ao marido. Mais alguns trechos de Suetônio mostram a relação com a família:

Ele construiu também algumas obras em nome dos outros, seus netos e sobrinho, a saber, sua esposa e sua irmã, como o pórtico e a basílica de Caio e Lúcio, também os pórticos de Lívia e Otávia e o Teatro de Marcelo. (Suet. Aug. 29, 4)

(...) Exceto em ocasiões especiais, ele usava roupas comuns para a casa, feitas pela irmã, esposa, filha ou netas; sua toga não era nem cerrada, nem frouxa. Sua listra de púrpura, nem estreita nem larga; e seus sapatos de sola um tanto mais alta, para fazê-lo parecer mais alto do que realmente era. (Suet. Aug. 73)

(...) Dois destes ${ }^{113}$ morreram quando ainda estavam na infância, e um quando saiu da infância, uma criança encantadora, cuja estátua, disfarçada de Cupido, Lívia ofereceu ao templo de Vênus Capitolino, enquanto Augusto tinha outra colocada em seu quarto de dormir e costumava beijá-la com carinho sempre que ele entrava nessa sala. (Suet. Calig. 7)

Nesses trechos é possível notar mais da relação familiar de Augusto; em uma casa cheia de mulheres, elas executavam um tradicional papel feminino confeccionando roupas para os homens da família, neste caso para Augusto. Seu relacionamento com as crianças também fica claro, os da citação destacada são bisnetos que Lívia e Augusto tinham em comum, filhos de Agripina Maior e Germânico. Entretanto, o ponto de maior destaque é a construção de obras em nome de seus familiares; isso fazia parte também da propaganda dele e contribuiu para a difusão dos nomes dessas mulheres e dos possíveis sucessores por todo o império.

A presença das esposas nos eventos, a realização de eventos por elas (geralmente próprios apenas para outras mulheres) ${ }^{114}$, as estátuas e constantes referências dessas mulheres como realizadoras de obras e doações para a cidade de Roma e para muitas das províncias, contribuíam para a forte propaganda de Augusto. Os membros de sua família estavam vinculados às questões da cidade e especialmente as mulheres faziam parte disso ${ }^{115}$. Com

\footnotetext{
${ }_{112}$ BARRETT, Anthony A. (2002). op. cit., p. 119.

${ }_{113}$ Referindo-se a dois bisnetos mortos, filhos de Agripina Maior e Germânico.

114 BARRETT, Anthony A. (2002). op. cit., p. 26; 31; 42; 47; 162.

${ }^{115}$ FLORY, Marleen B. TAPhA, p. 293-306. GRETHER, Gertrude. Livia and the Roman Imperial Cult. AJPh, Vol. 67, No. 3 (1946), p. 223-233. HEMELRIJK, Emily Ann. op. cit., p. 97145.
} 
obras em Roma membros da família de Augusto contribuíam para o embelezamento e melhorias na cidade, tornando a presença e relevância da família cada vez mais forte entre os habitantes da cidade, fato que também ocorria nas outras cidades do império que recebiam essas construções ${ }^{116}$. Lívia, após a morte de Augusto, ainda permaneceu com suas concessões, restaurações, ajuda a desabrigados, doações e ajuda em casos de incêndios 117 .

O trecho a seguir da pesquisadora Pryzwansky novamente ressalta que Suetônio se valia de ideais femininos em seus textos, assim como o uso de roupas confeccionadas pelas mulheres de sua família destacado anteriormente; dessa forma, especialmente na vida de Augusto o autor recorreu a essas alegorias. O trecho destaca também que elas foram difundidas por meio das representações iconográficas espalhadas pelo império e podem ser somadas à esta dinâmica as construções realizadas pelos integrantes da família, ou aquelas que Augusto fez em nome destes integrantes.

Suas biografias refletem alguns dos ideais femininos, tais como fertilidade, fidelidade, castidade e que foram anunciados em moedas imperiais, estátuas, e em textos como a Consolatio ad Liviam. É notável que quando Suetônio procura mostrar o quão "boa" era a vida familiar de Augusto, ele recorre às alegorias consagradas pelo tempo de tecelagem e da concórdia marital. ${ }^{118}$

A vida simples levada por Augusto, seus hábitos de vestimenta em conformidade com a prática, sempre atribuída às mulheres, de tecelagem e produção de roupas para os membros da família ${ }^{119}$ vão ao encontro com a política restauradora da moral e com a noção de adequação ao papel ideal da esposa ou outros papeis femininos ${ }^{120}$. O trecho a seguir destaca que a harmonia entre o casal, ou entre a família, pode representar a estabilidade do governo. A estabilidade do Estado seria reflexo das relações familiares.

\footnotetext{
${ }^{116}$ Conforme exposto nas páginas 30-31 deste trabalho sobre a propaganda augustana.

${ }^{117}$ BARRETT, Anthony A. (2002). op. cit., p. 172-173; 186-225.

${ }^{118}$ PRYZWANSKY, Molly M. op.cit., p. 235.

${ }^{119}$ MASSEY, Michael. As mulheres na Grécia e Roma antigas. Lisboa: Publicações EuropaAmérica, 1988, p. 61-81.

${ }^{120}$ DIXON, Suzanne. 2007, p. 17.
} 
(...) A família imperial via a si mesma como a primeira com um modelo de sentimento familiar "normal" e muitos governantes identificam a estabilidade de seus regimes com a harmonia (concordia) dos irmãos imperiais, maridos e esposas, parentes e crianças. ${ }^{121}$

Outro ponto de destaque nessa política de restauração moral é a participação de Lívia em diversos ritos próprios para mulheres. Especialmente a restauração do templo de Bona Dea e a dedicação dele e de sua própria casa à concordia - que poderia ter tanto o significado de harmonia na vida pública como no matrimônio - são atitudes relevantes da matrona, que se torna um exemplo para outras esposas seguirem ${ }^{122}$. Estas atitudes a colocam como uma esposa que atua na esfera adequada, participando das atividades próprias das mulheres. $O$ culto feminino ligado ao templo permaneceu ainda vinculado a Lívia durante o governo de outros imperadores de Roma. Além do vínculo com a harmonia, Lívia é ligada à paz, sendo o monumento da Ara Pacis dedicado a Augusto e inaugurado no aniversário dela ${ }^{123}$.

O vínculo com a ideia de concórdia associado ao amor entre o casal, presente em Suetônio, completa a figura ideal, submissa e leal de que Augusto, com suas inúmeras qualidades, necessitava ${ }^{124}$. Quando se fala em submissa, quer dizer que ela não ultrapassou o âmbito feminino de atuação, isso é, não se sobrepôs marido em atividades masculinas. Agripina Maior e Plancina amiga de Lívia - são exemplos de mulheres que se envolveram com atividades militares, a primeira auxiliando as tropas num momento de crise e a segunda participando de exercícios militares ${ }^{125}$, ou seja, são mulheres que se envolveram com atividades próprias dos homens. Lívia foi influente sem valerse de relacionamentos amorosos extraconjugais ou colocar-se a frente de seu marido em locais não adequados para mulheres. A influência dela reside no fato de saber permanecer na esfera feminina e colocar-se em cada situação de forma astuta e adequada para uma mulher romana. Suas opiniões eram

\footnotetext{
${ }^{121}$ DIXON, Suzanne. 1990, p. 235.

122 BARRETT, Anthony A. (2002). op. cit., p. 115-146.

${ }^{123}$ BARRETT, Anthony A. (2002). op. cit., p. 139. BARRETT, Anthony A. The Year of Livia's Birth. CQ, New Series, v. 49, n. 2, 1999, p. 632. FLORY, Marleen B. TAPhA, p. 297. GRETHER, Gertrude. AJPh, p. 226.

${ }_{124}$ Trecho de Suetônio que fala que Augusto amou Lívia até o fim de sua vida. Suet. Aug. 62, 2. Informações sobre a ideia de concórdia ligada ao relacionamento do casal. PRYZWANSKY, Molly M. op. cit., p. 139.

${ }^{125}$ Conforme exposto na página 70 deste trabalho.
} 
requisitadas pelo marido, seus filhos fizeram parte da domus Augusta, sua origem familiar foi relevante para firmar as bases políticas de Augusto, assim como ela própria foi importante para a propaganda augustana. Lívia, atuando de forma velada, conseguiu que muitas de suas requisições fossem realizadas pelo marido e manteve ainda a posição de matrona respeitável perante a sociedade romana.

A figura de Lívia durante o período em que Augusto esteve no poder permaneceu representada nas fontes primárias como a de uma esposa submetida ao domínio do marido. Ela cuidava das tarefas maternas; ou em última instância, como figura feminina de maior relevância na família que tomava para si a responsabilidade de cuidar das crianças e jovens da domus Augusta, quando os pais estavam ausentes ou mesmo mortos e banidos. Esta relevância se dava pelo fato de ser a esposa do príncipe e depois mãe do sucessor, mas também pela importância adquirida ao longo do governo do marido como mulher rica e influente. Essa figura e essa relação com a família e o marido eram obviamente idealizadas, no entanto, isso não pode ser usado para reduzir a relevância de Lívia ${ }^{126}$.

$\mathrm{Na}$ vida pública ela aparece sempre ligada à religião e à piedade, doações para Roma e outras cidades, apoio a poetas, restaurações e práticas de embelezamento da cidade. $\mathrm{O}$ trato nas fontes primárias, no geral, tende para uma visão positiva de Lívia nesse momento, no qual a admiração ao governo de Augusto vincula-se a ela. A partir da biografia de Tibério novas versões de alguns fatos são apresentadas; a representação de Lívia é um pouco diferente da presente na biografia de Augusto. Nunca, entretanto, sua figura é ligada à imoralidade ou desrespeito as tradições romanas.

\footnotetext{
${ }^{126}$ DIXON, Suzanne. The Sentimental Ideal of The Roman Family. In: RAWSON, Beryl (ed.). Marriage, divorce, and children in Ancient Rome. Canberra, Oxford: Humanities research Centre, Clarendon Press, 1991, p. 100-103.
} 


\section{Lívia e a política sucessória dentro da domus Augusta}

A preocupação de Suetônio não era descrever uma relação familiar entre mães, pais e filhos. Na biografia de Augusto, na de Tibério e em todas as Vidas descritas, a relação com os familiares aparece compondo a biografia e de forma a mostrar vícios ou virtudes do biografado ${ }^{127}$. Augusto e sua propaganda fazem o seu convívio com os jovens da família aparecer no texto de Suetônio, entretanto, não se deve pensar apenas nas relações familiares entre eles. Há uma preocupação política com os jovens, suas atitudes podem gerar crises, como o caso da filha de Augusto, Júlia. Suas indiscrições e adultérios somente tornaram-se preocupantes quando ela envolveu-se com o filho de Marco Antônio e Fúlvia, Júlio Antônio. Neste caso, as possíveis implicações políticas foram pensadas ${ }^{128}$.

A pesquisadora Molly Pryzwansky destaca em sua tese que na obra de Suetônio os papeis familiares que as mulheres exercem - o de mãe, filha, avó, tia, sobrinha, dentre outros - podem ser qualificados, podendo variar a qualificação de papel para papel: uma "boa" mãe não necessariamente foi uma "boa" esposa. As mães aparecem nas biografias em raras ocasiões, sendo citadas especialmente nos nascimentos; depois as que podem ser consideradas "más" aparecem ao longo dos textos interferindo nas decisões dos filhos, principalmente nas atividades políticas. Desta forma, as mulheres podem ser qualificadas em melhores ou piores de acordo com as interferências na vida pública e privada dos homens aos quais elas estão vinculadas. Esta qualificação não serve apenas para identificá-las como boas ou ruins, mas alteram a forma como o autor as trata ao longo das Vidas. Como exemplo, vejamos Ácia, mãe de Augusto, que pode ser considerada uma "boa" mãe ${ }^{129}$; mesmo com as preocupações com a segurança do filho, logo após a morte de Júlio César, ela é descrita apenas como estando apreensiva com a situação de Otaviano como herdeiro de César. Entretanto ela não tem uma atuação efetiva,

\footnotetext{
${ }^{127}$ CIZEK, Eugen. Structures et idéologie dans "Les vies des douze Césars" de Suétone. Bucuresti : Editura Academiei ; Paris : Les Belles lettres, 1977, passim.

${ }_{128}^{128}$ Vel. Hist. 2, 100, 3-5.

129 PRYZWANSKY, Molly M. Feminine Imperial Ideals in the Caesares of Suetonius. Dissertation (Doctor of Philosophy) - Department of Classical Studies - Graduate School of Duke University, 2008, p. 46-50; 58.
} 
e seu marido - o ex-cônsul Lúcio Márcio Filipo - é citado como se opondo fortemente a isso ${ }^{130}$.

As mães consideradas "más" aparecem ao longo dos textos interferindo nas vidas dos filhos já adultos. Mas uma mãe "má" não torna um imperador "mau", apenas se ele se submete ao domínio de outrem ${ }^{131}$. Pensemos em Augusto, mesmo com algumas passagens descrevendo a influência de sua esposa ele não foi dominado por ela. Atendia aos pedidos de sua esposa na medida em que considerava isso pertinente ou não, nunca ignorando os valores romanos que ele defendia - como o da cidadania plena.

Tendo em vista o anteriormente exposto sobre a tese de Pryzwansky, Lívia pode ser considerada uma mãe "má"; ao longo do principado de seu filho - Tibério - ela aparece algumas vezes interferindo em suas decisões e é acusada de desejar o poder. A visão de Tácito sobre ela é negativa e o autor atribui a responsabilidade por algumas mortes e alguns planos contra integrantes da família a Lívia. Em Suetônio a matrona aparece ajudando o filho a alcançar o poder e depois, mesmo com citações mostrando sua possível demanda de divisão deste, ela é vista de forma mais positiva.

\subsection{A morte de Augusto e a ascensão de Tibério ao poder}

As passagens de Suetônio sobre a infância de Tibério não apresentam muito de seu convívio com a mãe, retratam brevemente a história da família em seus momentos de fuga durante o período de guerra civil e apoio a Marco Antônio ${ }^{132}$. Posteriormente um fato destacado pelo autor mostra que ele provavelmente compartilhava da atenção de Augusto com os jovens da família, tendo em vista que além de seu padrasto este era seu tutor ${ }^{133}$.

\footnotetext{
${ }^{130}$ Suet. Aug. 8, 2.

${ }^{131}$ PRYZWANSKY, Molly M. op. cit., p. 55.

132 Suet. Tib. 6, 1-2.

${ }^{133}$ BARRETT, Anthony A. Livia: First Lady of Imperial Rome. New Haven: Yale University Press, 2002, p. 19-23. HUNTSMAN, Eric D. Livia before Octavian. AncSoc, v. 39, 2009, p. 145-149.
} 
Aos nove anos realizou um elogio ao seu falecido pai no rostro. Depois, quando ele estava chegando à puberdade, acompanhou a carruagem de Augusto em seu triunfo, após o Áccio, montando o cavalo de tiro dianteiro esquerdo, enquanto Marcelo - filho de Otávia - montava o da direita. Presidiu, também, o festival da cidade e participou dos jogos de Tróia durante as apresentações no circo, liderando um grupo de meninos mais velhos. (Suet. Tib. 6, 4)

A passagem descreve que durante a adolescência e junto de Marcelo, filho de Otávia, Tibério acompanhou Augusto no triunfo do Áccio. Este trecho não serve como prova para teorias de que ele sempre foi um potencial candidato a sucessão de Augusto, mas o coloca junto da família nos eventos, participando da propaganda augustana que colocava as crianças e mulheres nos eventos públicos e provavelmente compartilhando da mesma educação formal.

A primeira interferência de Lívia na biografia de Tibério se dá quando o filho parte para Rodes ${ }^{134}$. Entretanto é necessário considerar os fatos que o levaram a este exílio espontâneo. Após a morte de Agripa, Júlia já havia dado à luz aos futuros herdeiros de Augusto, Lúcio e Caio; porém é necessário observar que ela era a filha do imperador e que mantê-la fora de um matrimônio pensado pela própria família poderia colocar em risco todo o governo. Suetônio informa que antes mesmo do casamento, Júlia já tinha um comportamento lascivo, aproximando-se de Tibério enquanto seu marido Agripa ainda era vivo ${ }^{135}$.

Casando-se com Tibério, Júlia deveria ficar longe de relações que viriam a colocar o principado em risco; entretanto, mesmo com esta suposta barreira envolveu-se em uma série de adultérios, cujo principal amante foi o filho de Marco Antônio ${ }^{136}$. Não devemos pensar que Augusto baniu a própria filha apenas por seu comportamento lascivo; ela já se comportava de tal forma antes de qualquer titulação - a saber, "Pai da Pátria" - recebida por seu pai e ainda, a política restauradora da moral, composta não somente da atitude de Augusto, como das leis, estátuas e intensa propaganda eram parte de um longo processo. Júlia foi banida porque em sua rede de adultérios envolveu-se

\footnotetext{
${ }^{134}$ Suet. Tib. 10, 2.

135 Suet. Tib. 7, 2.

${ }^{136}$ Vel. Hist. 2, 100, 3-5. BARRETT, Anthony A. Agrippina: sex, power, and politics in the Early Empire. London: Routledge, 1996, p. 19. ROGERS, Robert Samuel. The Conspiracy of Agrippina. TAPhA, v. 62, 1931, p. 147. PRYZWANSKY, Molly M. op. cit., p. 214.
} 
com o filho de um inimigo político do pai, filho de Marco Antônio. Dentre as implicações possíveis para este relacionamento poderia estar o fim do domínio de Augusto; seu assassinato ou algum golpe político poderiam ser tramados pelo amante junto de sua filha.

O exílio espontâneo de Tibério pode ter sido pelo desgosto com a esposa adúltera, pode também ser atribuído a um não posicionamento como concorrente ao poder dos jovens filhos adotivos de Augusto ${ }^{137}$. Entretanto o afastou da potencial crise política dos adultérios de sua mulher. A intervenção de Lívia nesse período garantiu ao filho o cargo de legatus de Augusto e posteriormente seu retorno a Roma ${ }^{138}$. Como destaca a citação a seguir Lívia auxiliou o filho durante seu exílio espontâneo e garantiu a ele um cargo político:

Assim ele permaneceu em Rodes contra a sua vontade; obtendo, com dificuldade, por meio da ajuda de sua mãe a garantia da permissão de que, embora longe de Roma, ele deveria receber o título de Legado de Augusto, de forma a esconder sua desgraça. (Suet. Tib. 12, 1)

Depois da morte dos dois herdeiros do imperador, Tibério é adotado em 4 d.C. ${ }^{139}$. Sobre isso os trechos das fontes destacados a seguir atribuem, claramente, à Lívia o convencimento de Augusto para realizar tal ato e que relembrou constantemente o fato em sua velhice. Provavelmente isso era uma forma de mostrar ao filho que ele encontrava-se no poder devido à influência dela sobre o marido, o que também poderia vir a ser utilizado como argumento quando algum dos seus pedidos fosse negado - uma Lívia manipuladora neste caso; entretanto, Tácito tem uma visão negativa dela.

Eu também estou ciente de que alguns escreveram que Augusto, tão abertamente e sem reservas, desaprovava os modos austeros dele; que às vezes interrompeu suas conversas mais livre e mais leves quando Tibério aparecia. Todavia vencido por súplicas de sua esposa, ele não rejeitou sua adoção, ou talvez até mesmo tenha sido conduzido por considerações egoístas, que com tal sucessor ele próprio poderia um dia ser mais lamentado. Porém depois de tudo, eu não posso ser levado a acreditar que um imperador da máxima prudência e previsão agiu sem consideração, especialmente em um assunto de tamanha importância. É minha opinião que

\footnotetext{
137 Suet. Tib. 10, 1; 11, 5 .

138 Suet. Tib. 13, 2.

139 PRYZWANSKY, Molly M. op. cit., p. 84, 99.
} 
depois de pesar as falhas e os méritos de Tibério, ele decidiu que o último preponderava; especialmente desde que assumiu o compromisso de honra perante o povo de que ele estava adotando Tibério para o bem de Roma, fazendo alusão a ele em várias cartas como um general mais capaz e a única defesa do povo romano. (Suet. Tib. 21, 2-3)

Augusto hesitou em colocar Germânico - neto de sua irmã e o tema de louvor de todos os homens - à frente do domínio romano. Entretanto, pressionado pelos pedidos da sua esposa, havia introduzido Germânico na família de Tibério, e Tibério na sua: um benefício que a já idosa matrona se lembrava e clamava. (Tac. Ann. 4, 57, 5)

As circunstâncias do exílio do enteado tinham desagradado Augusto, mas Tibério era um militar de grande capacidade e muito respeitado. O imperador, mesmo influenciado por sua esposa, pesou as capacidades dele e também sua idade, tendo em vista que os dois outros nomes presentes nesse momento de adoção, Germânico e Agripa Póstumo, eram jovens demais para tão importante posição. Agripa Póstumo foi adotado no mesmo período como filho de Augusto, sendo o último filho vivo de Júlia - e Germânico adotado como filho de Tibério, unindo novamente a família de sua esposa à sua. A fama de Germânico nesse momento ainda era em grande parte herança de seu pai Druso, filho de Lívia; pouco depois ele casou-se com Agripina Maior, filha de Júlia e Agripa, e tiveram nove filhos, dos quais seis sobreviveram ${ }^{140}$.

Lívia é considerada a maior influência na escolha do filho como herdeiro e sucessor do marido e durante os anos seguintes é atribuído a ela o banimento de Agripa Póstumo ${ }^{141}$; todavia as atividades referentes a ele não obtiveram o mesmo destaque quanto as dos irmãos Lúcio e Caio, como por exemplo, no ano 5 d.C. no seu recebimento da toga viril em que não houve honras especiais ${ }^{142}$. Suetônio descreve o banimento do jovem pelo seu temperamento violento e identifica dois momentos do banimento, no segundo momento Agripa Póstumo passa a ser vigiado por uma guarda armada ${ }^{143}$. Tácito considera a ação de Lívia sobre um Augusto já idoso e dessa forma o banimento de Agripa e a adoção de seu filho teriam sido obtidos. Todavia deve ser considerado também, assim como Suetônio apresenta, que mesmo com a

\footnotetext{
${ }^{140}$ BARRETT, Anthony A. (2002). op.cit., p. 55-56.

141 Tac. Ann. 1, 3, 4.

142 Dio Cas. Hist. 55, 22-4. BARRETT, Anthony A. (2002). op. cit., p. 57.

${ }^{143}$ Suet. Aug. 65.
} 
influência da mãe, Tibério apresentava-se mais experiente em atividades políticas e militares ${ }^{144}$.

Nos anos que seguem até a morte de Augusto, Tibério continuou exercendo suas atividades militares e seus êxitos renderam-Ihe um debate no Senado sob qual título the seria conferido. Augusto opôs-se aos propostos dizendo que the bastavam os que ele herdaria após sua morte ${ }^{145}$ e dessa forma confirmou a posição de Tibério como seu sucessor.

Sobre a questão sucessória é necessário considerar que a transmissão do poder para um filho ou algum outro homem não pode ocorrer por meio de testamento; cargos não são transmissíveis por meio de herança. A política propagandista realizada por Augusto tornou seus familiares conhecidos por todo o império e os homens assumiram posições no governo e participaram das atividades militares, vinculando-se ao governo. $O$ trecho a seguir destaca que Augusto recebeu como herança de Júlio César bens, clientela e o nome, mas o poder ele conquistou ao longo de anos.

As implicações dessa política são múltiplas, pois os bens a serem transmitidos pertencem a duas categorias. Alguns são bens clássicos - um nome, um patrimônio, clientelas ou fiéis -, cuja importância e prestígio o próprio sucesso de Augusto ampliara prodigiosamente. Um outro, ao contrário, é um bem novo: o próprio poder. Otaviano só herdara de César os primeiros bens, seu nome (por adoção testamentária, confirmada por uma lei curial), o núcleo inicial de seu patrimônio e de sua clientela; ele levara dezesseis anos, de 44 a 28 a. C., para conquistar o segundo. Faltava-lhe ainda transmiti-lo. ${ }^{146}$

Augusto cria uma descendência legítima a partir do uso de seu poder de paterfamilias e dos recursos que the oferecia o direito romano, como a adoção e o divórcio. Filha, sobrinhos e enteados são utilizados nessa criação da domus Augusta por Otaviano e mais tarde por seus sucessores. Todavia, esta descendência legítima não poderia receber cargos por meio de testamento; o poder de Augusto não estava nos cargos que ele exerceu, mas sim no recebimento de poderes não vinculados às magistraturas. Ele recebeu no ano de 23 a.C. os poderes tribunicia potestas e imperium maius: o primeiro é o

\footnotetext{
${ }^{144}$ Tac. Ann. 1, 4.

${ }^{145}$ Suet. Tib. 17, 2.

${ }^{146}$ CORBIER, Mireille. Poder e parentesco. A família Júlio-Cláudia. Tradução de Consuelo Fontes Santiago. Classica, São Paulo, 5/6, 1992/1993, p. 169.
} 
poder do tribuno da plebe, cargo que não havia exercido e nem mesmo poderia exercer por ser um patrício; mas com os poderes deste, ele poderia exercer a intercessio - um veto a todo ato de um magistrado e opor às decisões senatoriais - assim como propor plebiscitos. O segundo permitia que Augusto exercesse seu imperium (poder de comando e de aplicar a lei no âmbito de sua magistratura) por todas as áreas do império. Ainda, ele recebeu em 19 a.C. o poder consular por toda a vida e o direito de usar os fasces. Esta é a autoridade maior que a de todos os magistrados romanos que Augusto fala em suas Res Gestae. Estes poderes diferem dos poderes recebidos pelos magistrados que são, oficialmente, anuais e colegiados; Augusto não estava exercendo um cargo, ele não tinha um colega para vetá-lo e seu imperium era maior que o de todos. A partir deste ponto Augusto pode definir sua linha sucessória associando os candidatos a ele durante seu governo ${ }^{147}$.

A sucessão esteve ligada à adoção, porém somente isso não tornaria um filho o sucessor de Augusto. Ele concedeu ao candidato à sucessão os mesmos poderes que ele havia recebido sem vínculo com cargos; a diferença era que os poderes eram concedidos por um período de cinco anos renováveis. A associação aos poderes tornou-se a forma de identificação dos sucessores; tanto Agripa quanto Tibério receberam estes poderes; e por possuir estes Tibério pode convocar uma reunião com o Senado logo após a morte de seu pai adotivo. ${ }^{148}$

Ainda que a transmissão não fosse pela adoção ou o pertencimento a domus Augusta, os integrantes buscaram relembrar seus vínculos com Augusto e também com Lívia durante suas vidas como forma de valorização pessoal; buscaram relembrar que faziam parte dessa família legitimada pela propaganda augustana - Cláudio não possuiu vínculo adotivo, mas buscou em seus casamentos e atitudes mostrar-se como parte dessa família. ${ }^{149}$

A domus Augusta foi criada utilizando especialmente as mulheres da família, todavia houve outros comportamentos, como o não reconhecimento de filhos bastardos - é o caso de Ptolomeu Cesário, filho de Júlio César e da

\footnotetext{
${ }^{147}$ GRUEN, Erich S. Augustus and the Making of the Principate. IN: GALINSKY, Karl (ed.). The Cambridge Companion to The Age of Augustus. New York: Cambridge University Press, 2005, p. 36-43.

${ }_{148}$ GRUEN, Erich S. op. cit., p.43-44; 48-50.

${ }^{149}$ CORBIER, Mireille (1992/1993). Classica, p. 194-197.
} 
rainha Cleópatra. Há, ainda, uma série de novas medidas que incluem a criação de títulos de dignidade; aumento do capital simbólico com a ajuda dos ascendentes vivos e dos já falecidos, por meio de intensa propaganda fazendo uso da memória genealógica; e o uso de um nome: Imperator Caesar. ${ }^{150}$

Otaviano utilizou um nome que fazia referência a sua adoção na família Júlia com o uso do Caesar, e Imperator era a aclamação que os soldados faziam ao seu general vitorioso, estímulo ao triunfo; seu pai adotivo, Júlio César, usava o título "Imperator Caesar" e após sua morte Otaviano recebeu como herança este título. Posteriormente foi incluído junto a este Augustus, após o título ser concedido pelo Senado. Os homens em posição sucessória são chamados de Césares e ainda, a partir de então, a denominação dos imperadores passa a ser "César Augusto". Otaviano com essas atitudes diferenciava sua família das demais famílias aristocráticas romanas. A utilização de nomes que pertenciam aos membros de maior relevância foi outra medida utilizada pelos membros da domus Augusta; Druso, Drusila, Otávia, Antônia foram utilizados de forma a evocar suas origens nobres, como no caso do imperador Cláudio que escolheu para suas filhas os nomes de Cláudia Antônia e Cláudia Otávia, fazendo menção à sobrinha e à irmã de Augusto respectivamente. ${ }^{151}$

Os matrimônios dos membros de sua família e do próprio Augusto foram utilizados para criação de alianças políticas e também para a construção de uma família imperial, que durante gerações renovaram as alianças, especialmente entre as famílias de Lívia e Augusto. Esta renovação das alianças ficou sob a potestas de Augusto e depois passou ao controle de seu sucessor Tibério, mantendo também o patrimônio indivisível e sob o controle do imperador. ${ }^{152}$

Os homens da família tendiam a viver menos que as mulheres, levando Augusto e seus sucessores a realizar novas uniões tendo em vista novos herdeiros e alianças; estes homens faleciam na prática de atividades militares, por doenças e também sendo assassinados. Alguns assassinatos ocorreram dentro da domus Augusta. Potenciais sucessores foram eliminados não apenas

\footnotetext{
${ }^{150}$ CORBIER, Mireille (1992/1993). Classica, p. 170-171.

${ }^{151}$ Idem.

152 Ibidem, p. 175-178.
} 
por Augusto (no caso do filho de Cleópatra), como pelos outros imperadores da dinastia Júlio-Claudiana. Isto ocorreu com membros da própria família, todavia ocorreu, também, com membros das famílias que outrora estavam sendo vinculadas por meio de matrimônios com algumas das mulheres da família dos imperadores de forma a obter apoios políticos. ${ }^{153}$

A relevância adquirida por essa família foi enorme, isto em grande parte pela propaganda augustana que os colocava em evidência por toda a cidade e em todos os momentos de importância para os romanos. Assim os integrantes da domus Augusta estavam presentes nas cerimônias oficiais e nas representações; os juramentos de fidelidade se dirigiam a Augusto e sua família, sob Tibério à domus ${ }^{154}$, destacando não somente os feitos do imperador, mas também legitimando a família.

Os momentos finais e a morte do imperador são descritos por Suetônio e Tácito de forma a incluir sua esposa Lívia nos eventos.

Em seguida, mandou-os todos embora à medida que perguntava a alguns recém-chegados da cidade sobre a filha de Druso, que estava doente; ele faleceu repentinamente enquanto estava beijando Lívia, proferindo estas últimas palavras: "Lívia, viva consciente do nosso casamento, e adeus", assim, abençoado com uma morte fácil e tal qual ele sempre desejou. (Suet. Aug. 99, 1.)

O trecho de Suetônio aponta Lívia ao lado de Augusto em seus momentos finais e as implicações da frase dita por ele podem ser muitas. Augusto pode ter pedido para a esposa permanecer com sua postura de matrona respeitável; ele pode ter assegurado a importância da posição dela como esposa do imperador; ele pode ter dito uma frase que expressava uma relação longa e de sentimentos profundos, mesmo sem frutos do casamento. Ou ainda, Augusto estava lembrando Lívia da criação de uma domus Augusta em que as famílias de ambos se fundiram e deram a eles descendentes em comum; sendo a última decisão de Augusto incluí-la em sua própria família por meio de adoção e a tornando Júlia Augusta, sua filha. As reais implicações

\footnotetext{
${ }_{154}^{153}$ CORBIER, Mireille (1992/1993). Classica, p. 185-186.

154 Ibidem, p. 194-195.
} 
dessa frase, ou mesmo, da adoção não foram explicitadas por Augusto, entretanto é impossível negar a relevância de Lívia ${ }^{155}$.

Tácito apresenta a morte de Augusto de outra forma: Lívia é acusada de estar ligada ao seu óbito e isso se deve a possível reaproximação do príncipe com seu outro filho adotivo Agripa Póstumo. Augusto teria viajado até o jovem junto de Fábio Máximo e a esposa dele - Márcia - teria contado para Lívia sobre seus planos.

Embora esses temas e afins estivessem sob discussão, a doença de Augusto começou a se tornar mais grave e alguns suspeitavam de uma intervenção por parte da esposa. A razão para um boato ter chegado a esse ponto: poucos meses antes o imperador, confiando em alguns poucos escolhidos e apenas com a participação de Fábio Máximo, havia navegado para a Planásia em uma visita a Agripa. "Há lágrimas e sinais de afeto de ambos os lados, sendo abundante o suficiente para aumentar a esperança de que o jovem poderia ainda ser reposto na casa de seu avô. Máximo havia revelado o incidente à sua esposa Márcia; e Márcia à Lívia. Isto teria chegado ao conhecimento do César e após a morte de Máximo, que se seguiu em breve - possivelmente por sua própria mão -, Márcia tinha sido ouvida no funeral soluçando e repreendendo-se como a causa da destruição de seu marido". Independentemente da veracidade do caso, Tibério mal tinha posto os pés na llíria quando foi chamado por uma carta urgente de sua mãe; não se sabe com certeza se ao chegar à cidade de Nola, ele encontrou Augusto ainda respirando ou sem vida. Uma guarda rigorosa foi colocada por Lívia para cercar a casa e as ruas, enquanto avisos otimistas foram emitidos em intervalos, até que as medidas ditadas pela crise foram tomadas: um relatório anunciando simultaneamente que Augusto havia falecido e que Tibério Nero era o senhor do império. (Tac. Ann. 1, 5)

O primeiro ponto a se observar quando se pensa na reconciliação com Agripa é o de que Augusto não conseguiria viajar para iniciar tal aproximação sem que Lívia notasse sua ausência, ainda mais improvável se pensarmos em Augusto já doente no período. O imperador deixou de comparecer, também, a um encontro com Druso no Senado, o filho de Tibério; este ponto faz com que a ideia de que Augusto tivesse encontrado com Agripa seja considerada, pois na mesma reunião não compareceu Fábio Máximo. Todavia, é necessário pensar que o imperador encontrava-se já enfermo nessa época e até mesmo

\footnotetext{
${ }^{155}$ BAUMAN, R. A. Tanaquil-Livia and the Death of Augustus. Historia, v. 43, n. 2, 1994, p.
} 178. 
Tibério não esteve presente nesta reunião no Senado. Em seus breves momentos de melhora, Augusto iniciou algumas viagens, acompanhado de Lívia, passando por Napóles e em seu retorno, com o agravamento de sua condição, permaneceu em Nola ${ }^{156}$. Em última instância, se Augusto realmente pensasse em uma reconciliação porque ele colocaria uma guarda armada vigiando o filho adotivo em seu exílio? ${ }^{157}$

A acusação de participação de Lívia na morte de Augusto se dá pela suposta defesa do lugar de seu filho como sucessor do marido. $O$ trecho de Tácito deixa claro que ela avisou o filho da situação de seu pai adotivo e que este veio se encontrar, ou ao menos tentar se encontrar, com o imperador ainda vivo. Até sua chegada a casa foi mantida cercada por ordem dela, devemos considerar que o anúncio da morte do imperador causaria imenso abalo nos romanos e uma das lembranças familiares deles era a enorme comoção que levou a população romana a queimar o corpo de Júlio César, pai adotivo de Augusto.

Cercar a casa e enviar notícias otimistas sobre sua saúde poderiam ser formas de impedir o acesso à informação da morte de Augusto antes que Tibério pudesse chegar para assumir sua função, mas não deixa de ser uma atitude possível diante dessa situação. Uma atitude que visava à segurança de Augusto, caso ainda estivesse vivo, e excessos causados pelo abalo da população. Tácito inclui ainda a informação de que a morte de Augusto foi anunciada junto da ascensão de Tibério ao poder. Este anúncio, ligado às notícias otimistas e ao cercamento da residência, pode ser uma forma de evitar atitudes de descontroles mediante a trágica revelação do falecimento de Augusto.

Existiram também boatos de que Lívia teria envenenado o próprio marido com um figo, pois Augusto teria sido encontrado com este fruto e alguns outros alimentos ${ }^{158}$. Lívia era conhecida por sua ligação com os figos, por plantá-los e até mesmo ter desenvolvido uma variedade que recebeu seu nome

${ }^{156}$ Permanência de Augusto em Nola. Suet. Aug. 98, 5. Sobre a reunião do Senado em que Augusto e Fábio Máximo não estavam e a presença de Lívia na viagem junto do marido. BARRETT, Anthony A. (2002). op. cit., p. 63-72.

${ }^{157}$ Informações sobre a guarda armada que vigiava Agripa Póstumo. Suet. Aug. 65,4. Sobre a questão da suposta reconciliação entre Augusto e Agripa. ROGERS, Robert Samuel (1931). TAPhA, p. 148.

${ }^{158}$ Figo era um dos alimentos favoritos de Augusto e ele costumava comê-los sempre, geralmente após o jantar. Suet. Aug. 76, 1. 
159. Para tal ato, a matrona deveria considerar então matar o marido e chamar o filho antes de assassiná-lo, correndo contra o tempo e contra os visitantes que foram até a casa em Nola. Lívia possuía, também, interesses em remédios curativos e seria mais fácil envenenar o esposo com algo assim do que com uma fruta ${ }^{160}$. Outras fontes sobre a morte do imperador não tratam dessa possibilidade de envenenamento; Tácito informa que algumas pessoas desconfiaram de Lívia, como tratado anteriormente, e Suetônio não acusa Lívia desse crime. Não é impossível que isso tenha ocorrido, nem possível afirmar tal ponto, pois cenas semelhantes de envenenamento do marido e cercamento da casa ocorrem novamente na descrição da morte de Cláudio e a culpa é atribuída a sua esposa Agripina Menor.

O único negócio que ele permitiu ser discutido na primeira reunião do Senado foi o funeral de Augusto. O testamento, trazido pelas Virgens Vestais, especificava Tibério e Lívia como herdeiros; Lívia foi adotada na família Júlia com o nome de Augusta. Como legatários em segundo grau, ele mencionou seus netos e bisnetos; em terceiro lugar, os nobres proeminentes - um lance de ostentação para os aplausos da posteridade, já que ele detestava a maioria deles. (Tac. Ann. 1, 8, 1-2.)

Lívia, independente de qualquer boato de assassinato, tornou-se herdeira de Augusto recebendo parte de sua fortuna; sendo incluída na família Júlia e tornando-se Augusta, como destacado no trecho anterior; ela foi a primeira mulher com este nome ${ }^{161}$. Mesmo não conhecendo as reais intenções dele com essa ação, Lívia encontrava-se em uma posição ainda mais especial do que a que já ocupava, ela era dotada de fortuna, contatos e querida pela população e por importantes figuras políticas do período.

O convívio e as atitudes com o filho nesse primeiro instante seguem uma conduta normal para uma família que na eminência do falecimento do pai, a mãe busca avisar o filho do ocorrido e este faz o possível para encontrá-lo ainda vivo; situação semelhante à vivida na época da morte do irmão Druso. Lívia não somente tem uma posição destacada na morte do esposo como nos primeiros momentos após este óbito, a responsabilidade da morte de Agripa

\footnotetext{
${ }^{159}$ PLÍNIO, História Natural, 15, 70 apud BARRETT, Anthony A. (2002). op. cit., p. 113.

${ }^{160}$ Lívia sendo acusada de matar o marido envenenado em Dio Cas. Hist. 56, 30. Interesses de Lívia por remédios em BARRETT, Anthony A. (2002). op. cit., p. 66.

${ }^{161}$ CORBIER, Mireille (1992/1993). Classica, p. 171.
} 
Póstumo é atribuída a ela, tendo em vista que a proximidade com ele teria sido o motivo do suposto assassinato do marido.

\subsection{A relação entre mãe e filho: a influência de Lívia no governo}

O primeiro fato de destaque da relação familiar entre Lívia e o filho, no início de seu principado, é a morte do irmão adotivo Agripa Póstumo. Após o falecimento do imperador, o único concorrente ao poder era o outro filho adotivo de Augusto, que se encontrava exilado e sob vigilância de uma guarda armada.

O último [Agripa Póstumo] foi morto por um dos soldados designados para protegê-lo, que recebeu uma carta em que estava encarregado de fazer o ato. Não se sabe, porém, se Augusto deixou esta carta quando ele morreu para remover uma futura fonte de discórdia, ou se Lívia a escreveu no nome do marido; e em último caso, se era com ou sem a conivência de Tibério. De qualquer forma, quando o soldado informou que havia cumprido sua requisição, Tibério respondeu que ele não tinha dado esta ordem e que o homem deveria prestar contas ao Senado. Aparentemente tentando evitar ódio na época, para posteriormente seu silêncio levar o assunto ao esquecimento. (Suet. Tib. 22.)

De acordo com Tácito, Agripa estava desarmado - não apresentando resistência - e Tibério não fez nenhuma referência sobre o assunto, deixando a entender que era uma decisão de seu pai; entretanto o autor considera que era mais provável que Lívia ou Tibério fossem os responsáveis por tal ato ${ }^{162}$. Quando o soldado foi prestar contas a Tibério, este negou qualquer ordem. Lívia teria feito isso sem o conhecimento do filho? Consideramos improvável que ela tenha feito tal ato, tendo em vista que o próprio Augusto exilou seu filho adotivo, como outrora tinha feito com a filha biológica e não apenas isso: colocou-o sob vigilância de uma guarda armada. Se Augusto realmente estivesse disposto a reconciliar-se com Agripa Póstumo, talvez ele tivesse incluído o jovem em seu testamento. O falecido imperador havia deixado seu testamento sob os cuidados das Virgens Vestais; neste temos Tibério com dois

${ }^{162}$ Tac. Ann. 1, 6. 
terços de sua fortuna e Lívia, adotada na família Júlia sob o nome de Júlia Augusta, com um terço. Com a escolha de seu sucessor confirmada pelo recebimento dos poderes, possivelmente a adoção de Lívia na família serviu para garantir um vínculo maior com Augusto - em Roma a filiação deriva do pai, dessa forma ela passa a ser da família Júlia, assim como o filho Tibério que havia sido anteriormente adotado, agora o pai adotivo dele e a mãe estavam na família Júlia. ${ }^{163}$

$\mathrm{O}$ fato de tê-la adotado, ou mais precisamente o fato dela receber $\mathrm{o}$ nome Augusta causou, no entanto, alguns questionamentos. Qual o objetivo de Augusto com essa atitude? Teria Lívia sido incluída no poder? Como Tibério e o Senado agiram com essa questão?

Contrariado com sua mãe Lívia e alegando que ela reivindicou uma parte igual no principado, ele evitava reuniões freqüentes, longas e confidenciais conversas com ela para evitar a aparência de ser guiado por seus conselhos; considero o fato de que ele tinha por hábito, periodicamente, desejá-los e seguilos. Ele ficou muito ofendido também por um decreto do Senado, que previa que "Filho de Lívia", bem como "Filho de Augusto" devia ser colocado em suas inscrições honorárias. Por esta razão, não suportaria que ela fosse chamada de "Mãe", nem receber qualquer notável honra pública. Mais do que isso, muitas vezes ele a avisou para não interferir em assuntos de importância e impróprios de uma mulher; especialmente depois que soube que em incêndios perto do templo de Vesta, ela esteve presente em pessoa, exortando o povo e os soldados para esforços maiores, como ela fazia quando seu marido estava vivo. (Suet. Tib. 50, 2-3)

O trecho de Suetônio e o trecho a seguir de Tácito deixam claro que após a morte de Augusto, Lívia recebeu muita atenção por parte dos senadores. Tibério também a acusa de desejar a divisão do poder e por isso procurou se manter longe dela, mesmo que Suetônio informe que os conselhos dela ocasionalmente eram requeridos. Pensemos por que as ideias dessa matrona poderiam ser de grande valia para o novo imperador. Augusta era uma mulher aristocrata e que tinha vivido os mais importantes momentos do final da República e do principado de Augusto em meio as famílias envolvidas nos conflitos e jogos de poder. Ela ainda tinha realizado diversas viagens com o

${ }^{163}$ GRETHER, Gertrude. Livia and the Roman Imperial Cult. AJP, v. 67, n. 3, 1946, p. 233. DECKMAN, Alice A. Livia Augusta. CWe, v. 19, n. 3, 1925, p. 23. CORBIER, Mireille (1992/1993), Classica, p. 188. 
marido nas quais havia conhecido vários outros governantes, dessa forma poderia contribuir com o principado do filho devido aos seus contatos e vivência.

O poder de Lívia não provinha deste título. O poder do imperador também não provinha do título Augusto e sim dos poderes como tribunicia potestas e imperium maius, citados anteriormente e que não poderiam ser possuídos por mulheres. Certamente o título colocou Lívia em uma posição ainda mais relevante. As adulações do Senado vieram ao encontro dessa nova situação e deixaram ideias de que ela desejava o poder ganhar ainda mais força; como as de Dion Cássio que insistia que a matrona tentava exercer o poder e chegou até mesmo a escrever e receber cartas oficiais, apontando que as correspondências eram enviadas no nome de ambos. Tal fato não pode ser comprovado pela ausência de fontes, as cartas que sobreviveram até os dias atuais têm apenas o nome do imperador Tibério ${ }^{164}$. É sabido que Lívia enviou cartas ao rei Arquelau da Capadócia a pedidos do filho e convenceu o monarca a viajar até a cidade de Roma para receber clemência, alertando-o, no entanto, para o descontentamento de Tibério - pois em sua estadia em Rodes não recebeu nenhuma atenção do monarca. Ele veio a falecer quando chegou a Roma e seu reino incorporado ao império ${ }^{165}$.

Sobre a ida aos locais de incêndio presente no trecho de Suetônio, temos Augusta não apenas fazendo doações após o fogo - uma prática comum para mulheres -, ela ajudava durante as tentativas de combate ao fogo. Augusta foi até a região afetada, incentivou e encorajou as pessoas e soldados que combatiam os focos do incêndio. O combate à incêndios era uma atividade militar executada pelo cohortes vigilum e havia sido criada por Augusto, dessa forma o papel dela foi considerado por Tibério como um abuso a uma função masculina, uma função militar ${ }^{166}$. Pensemos que essa passagem relata, também, que ela se comportava dessa forma durante o governo de seu marido, não seguindo uma conduta adequada para uma mulher. Por que Suetônio apenas informa isso na biografia de Tibério? Novamente acreditamos que ele trata Lívia de formas diferentes nas biografias e nesta cabia destacar esta suposta atitude de interferência dela.

\footnotetext{
${ }^{164}$ Dio Cas.Hist. 55, 16, 2; 56, 47, 1; 57, 12, 2-3. BARRETT, Anthony A. (2002). op. cit., p. 154155.

${ }^{165}$ Tac. Ann. 2, 42.

${ }^{166}$ Dio Cas. Hist. 57, 16, 2. BARRETT, Anthony A. (2002). op. cit., p. 164.
} 
Após a morte de Augusto, Lívia não apenas se tornou Júlia Augusta como também Ihe foram oferecidos diversos títulos, como "Mãe da Pátria", "Mãe" ou ainda incorporado nas inscrições de Tibério, "Filho de Júlia"167 Suetônio usa ainda em seu texto "Filho de Lívia" ${ }^{168}$, entretanto usamos a forma apresentada a seguir por Tácito, que provavelmente obteve em suas consultas aos arquivos senatoriais. Essa titulação foi recusada por Tibério e até o período dos Severos nenhuma mulher foi oficialmente chamada de "Mãe da Pátria". A ideia de incluir "Filho de Júlia" nas inscrições do imperador é absolutamente estranha à prática romana, todavia demonstra a grande influência dela após a morte de Augusto. Acreditamos que o Senado não viu no título de Lívia uma divisão do poder e por isso ofertou para ela estas honras, eles reconheceram nela uma mulher influente, a viúva de Augusto e mãe do novo imperador ${ }^{169}$.

Augusta se beneficiou de um quinhão de adulação senatorial. Uma parte propôs dar a ela o título de "Mãe", alguns preferiram "Mãe da Pátria"; a maioria achava que a qualificação "Filho de Júlia" deveria ser acrescentada ao nome do César. Tibério declarou que os elogios oficiais para as mulheres deviam ser mantidos dentro de limites e que ele próprio iria usar de prudência, mesmo no caso dos que lhe fossem oferecidos (na verdade ele estava aflito por ciúme, considerando a elevação de uma mulher como uma degradação de si mesmo); se recusou a permitir até mesmo a concessão de um lictor para ela, proibiu tanto um Altar de Adoção como outras honras propostas de natureza semelhante. (Tac. Ann. 1, 14, 1-2)

Durante o principado de Tibério, Augusta foi incluída, junto de seu filho, nos votos pela segurança de ambos; e seu aniversário, também, passou a ser oficialmente comemorado em Roma. A consagração do Divino Augusto colocou Augusta numa posição sem nenhum precedente, ela se tornou sacerdotisa do culto dedicado a ele. Mesmo pensando nas Vestais, o culto ainda tinha como sacerdote principal um homem. Somente na execução dessa função the era permitido o uso do lictor, assim como as Vestais ${ }^{170}$. Ainda, teve sua imagem difundida em estátuas e moedas ao longo do império ${ }^{171}$.

\footnotetext{
${ }^{167}$ Tac. Ann. 1, 14, 1.

${ }^{168}$ Suet. Tib. 50, 2 Conforme exposto nas páginas 65 deste trabalho.

169 BARRETT, Anthony A. (2002). op. cit., p. 157-159. DIXON, Suzanne. The Roman Mother. London: Routledge, 1990, p. 89-90. FLORY, Marleen B. TAPhA, p. 77. GRETHER, Gertrude. AJP, p. 233-236.

${ }_{170}$ BARRETT, Anthony A. (1996). op.cit., p. 160-161.

${ }^{171}$ ESDAILE, Katharine A. The Aged Livia. JRS, v. 4, Part 2, 1914, p. 139. GARDNER, P. A
}

New Portrait of Livia. JRS, v. 12, 1922, p. 33-34. GRETHER, Gertrude. AJP, passim. 
Uma das principais mostras da influência de Augusta foi o auxílio à carreira de alguns políticos romanos; pagamento de dotes para filhas que a família não poderia arcar; educação de crianças de famílias respeitáveis com parentes empobrecidos ${ }^{172}$. A ajuda política dela beneficiou nomes como Sexto Afrânio Burro, Prefeito do Pretório na época de Nero, que havia começado seus serviços como procurador dela; o avô do imperador Otão também conseguiu torna-se pretor com ajuda da matrona. Entretanto, o auxílio mais proeminente foi com o futuro imperador Galba. Ele herdou de Augusta cerca de cinquenta milhões de sestércios; ela também teria encorajado a carreira política dele e feito propaganda de suas capacidades. ${ }^{173}$

Os trechos destacados ainda falam sobre a tentativa de Tibério de não parecer guiado pela mãe, entretanto é notável que em casos como os Arquelau da Capadócia sua figura foi de grande utilidade. Logo, Tibério e Augusta vivenciaram uma situação familiar, com muita relevância política, que envolvia Germânico e sua esposa Agripina Maior, um casamento definido por Augusto.

Germânico e Agripina Maior casaram-se pouco depois da adoção de Tibério $^{174}$ - e da adoção de Germânico por este ${ }^{175}$. Ele era filho de Druso e Antônia Menor - o filho de Lívia e a filha Otávia; Agripina era a filha de Agripa e de Júlia, filha de Augusto. Este casal contava com uma importante ascendência e com a grande popularidade de Druso. Germânico, assim como seu pai biológico, ganhou fama pela atuação militar e junto de sua esposa teve nove filhos - dos quais seis sobreviveram -, passando uma imagem de casal fértil e promissor $^{176}$.

Entretanto, Germânico - como já dissemos - foi percorrendo a província da Gália para exigir os tributos, quando chegou a mensagem dizendo que Augusto não estava mais vivo. Casado com Agripina, a neta de Augusto, que havia lhe dado vários filhos e ele próprio neto de Lívia (ele era o filho do irmão de Tibério, Druso), era atormentado nada mais nada menos pelo

\footnotetext{
172 Dio Cas.Hist. 58, 2, 3.

${ }^{173}$ Ajuda de Lívia as carreiras de Galba e a família de Otão em Suet. Galb. 5, 2. Oth. 1, 1. Ditos de Tibério sobre o futuro promissor de Galba estão presentes em Tac. Ann. 6, 20, 3. DIXON, Suzanne. Reading Roman women: sources, genres and real life. London: Duckworth, 2007, p. 110.

${ }^{174}$ SHOTTER, David C. A. Agrippina the Elder: A Woman in a Man's World. Historia, v. 49, n. 3,2000 , p. 343.

${ }_{175}^{175}$ Suet. Calig. $1,1$.

${ }^{176}$ BARRETT, Anthony A. (2002). op. cit., p. 53. SMITH, Cecil H. A Portrait Bust of Agrippina. Burl. Mag., v. 11, n. 50, 1907, p. 100.
} 
ódio secreto de seu tio e se sua avó - ódio nascido dos motivos mais vivos quanto mais injustos. Druso ainda era uma memória viva da nação e acreditava-se que, se tivesse conseguido, teria restaurado o tempo de liberdade. O mesmo afeto e esperança eram centrados no jovem Germânico com a sua disposição despretensiosa e sua cortesia excepcional, tão distante da arrogância inescrutável da palavra e do olhar que caracterizavam Tibério. As animosidades femininas aumentaram a tensão e a antipatia que Lívia, uma irritável madrasta, tinha de Agripina, cujo temperamento não era sem uma pitada de fogo, embora a pureza da mente e devoção conjugal mantiveram seu espírito rebelde ao lado da justiça. (Tac. Ann. 1, 33.)

O excerto de Tácito mostra como os descendentes de Druso compartilhavam do carinho que a população romana tinha por ele. Seu filho Germânico e seus netos farão uso dessa descendência tanto quanto do vínculo com Augusto. O historiador destaca também a antipatia e o ódio que mãe e filho nutriam pelo jovem casal, especialmente Augusta que é chamada de madrasta - da mãe de Agripina, Júlia.

Um momento de tensão que envolveu o casal ocorreu logo após a morte de Augusto, quando eles enfrentaram um motim de soldados que levou Agripina Maior e o filho que os acompanhava no acampamento a partirem para garantir a segurança deles, como destaca o trecho a seguir. Neste momento Agripina que hesitava em partir, alegou que era o sangue divino de Augusto e que não temia perigos ${ }^{177}$. Agripina Maior sabia bem a importância da sua posição na família, ela era filha da única filha biológica de Augusto, e valeu-se sempre dessa situação ${ }^{178}$.

Ele hesitava e Agripina tratou a proposta com desdém, protestando que ela era descendente do divino Augusto e o perigo não iria a denegrir. Por fim, em meio a crises de choro, ele a abraçou junto do bebê e assim a convenceu a partir. $O$ bando de mulheres em lamúrias começou a partir - a esposa do comandante em fuga com seu filho recém-nascido junto ao seu peito e em volta dela as mulheres chorosas de seus amigos, retiradas como ela de seus maridos. Também não era menor a tristeza dos que permaneciam. (Tac. Ann. 1, 40, 4-5.)

\footnotetext{
177 Tac. Ann. 1, 40.

178 BARRETT, Anthony A. (1996). op. cit., p. 22. SMITH, Cecil H. Burl.Mag., p. 100.
} 
Outro momento relevante foi quando Agripina Maior atuou, extrapolando os limites entre os âmbitos masculinos e femininos, impedindo a destruição da ponte do Reno e impedindo também a desonra romana. Tácito destaca que ela atuou como um verdadeiro general, revistando as tropas e fornecendo-os o que necessitassem. Nessa época seu filho, Caio, percorria o acampamento vestido como um soldado, sendo apelidado de Calígula pelos militares por utilizar uma miniatura dos calçados que eles usavam. De acordo com o historiador, Tibério considerava tais atitudes cheias de segundas intenções ${ }^{179}$. É importante destacar que neste ponto não é o Tácito que considera suas atitudes duvidosas, 0 autor destaca bem que esta era a ideia do imperador Tibério.

A crise familiar atingiu seu ponto extremo quando Tibério nomeou procurador da Síria Cneu Calpúrnio Pisão. Pisão e sua esposa Plancina, amiga de Lívia, teriam sido orientados pelo imperador e sua mãe para obstar as esperanças de Germânico e perseguir Agripina. Dizia-se também que o imperador Tibério preferia Druso, seu filho biológico, a Germânico, entretanto os primos e irmãos mantinham uma relação amigável ${ }^{180}$. Pisão cuidou para que nas legiões da Síria, utilizando de intrigas, seus clientes ocupassem as posições mais relevantes, sem o conhecimento ou o consentimento de Germânico. Plancina, por sua vez, não se portava com o decoro necessário para uma mulher, participando dos exercícios de cavalaria e lançando injúrias a Agripina e ao marido dela ${ }^{181}$.

Era do conhecimento de Germânico esta situação com o casal, entretanto o fato de maior desavença foi após seu retorno do Egito, quando encontrou desfeitas as ordens que havia deixado às cidades e legiões; nessa altura, provavelmente, ele já se encontrava com a doença que colocaria fim a sua vida. Pisão partiu para a região da Selêucia e acompanhou o agravamento da saúde do inimigo. Foram encontrados em sua residência objetos ligados à feitiçaria aumentando ainda mais a desconfiança de que o casal seria responsável pelo envenenamento de Germânico ${ }^{182}$.

\footnotetext{
179 Tac. Ann. 1, 69.

180 Tac. Ann. 2, 43.

${ }^{181}$ Informações sobre as atitudes sem decoro de Plancina em Tac. Ann. 2, 55.5. Sobre o comportamento de Pisão e na Síria, assim como o comportamento de sua esposa. SHOTTER, David C. A. Historia, p. 344-349.

${ }^{182}$ Tac. Ann. 2, 69.
} 
Em seus momentos finais, ele se preocupou com a situação da esposa e de seus filhos ${ }^{183}$, que após sua morte partiram para Roma levando as cinzas dele. A comoção popular ao saber de seu falecimento foi enorme e Agripina foi chamada de glória de Roma e ainda de modelo das virtudes antigas. Esta situação mostrava que a ascendência do casal os colocava em uma relevante posição, que contava com o apoio popular. A descendência de Augusto - e ainda de Druso - será constantemente relembrada pelos filhos de Agripina Maior.

Nada, porém, impressionou tão profundamente Tibério como o entusiasmo que os homens acendiam em Agripina - "a glória de sua pátria, a última descendente de Augusto, o padrão inigualável de virtude antiga" assim a chamavam; e, voltandose para o céu e os deuses, rezaram para a sua conservação "e que possam sobreviver os seus perseguidores!" (Tac. Ann. 3, $4,3$.

Tibério e Augusta - e até mesmo Antônia Menor, mãe de Germânico não compareceram a cerimônia, na qual as cinzas foram depositadas no Mausoléu de Augusto. Tácito atribui isso à necessidade de não serem considerados dissimulados e dessa forma detiveram também a mãe de Germânico ${ }^{184}$.

Seguiram-se as acusações de responsabilidade pela morte de Germânico contra Pisão e Plancina, e o peso da influência de Augusta pode ser sentido novamente. Graças à interferência da matrona a contestação de sua amiga foi dissociada da defesa de Pisão, ela pode falar em sua própria defesa a ainda contou com o discurso do imperador para ajudá-la, deixando clara a intervenção de sua mãe. Ao fim, Pisão suicidou-se e suas imagens foram retiradas de Roma assim como suas inscrições; o filho teve os bens confiscados. Entretanto, foram-Ihe devolvidos como um ato de generosidade; e o Senado decidiu por atender ao pedido de Lívia com relação à Plancina ${ }^{185}$.

\footnotetext{
${ }^{183}$ Tac. Ann. 2, 70.

184 Tac. Ann. 3, 3.

185 Detalhes sobre o julgamento do casal em Tac. Ann. 3, 15-17. Resultados do processo e informações sobre o que ocorreu com a família de Pisão em BARRETT, Anthony A. (2002). op. cit., p. 89-90.
} 
A reputação de Augusta sofreu, ao menos um pouco, com a questão da defesa de sua amiga um declínio ${ }^{186}$. Todavia a matrona continuava sendo uma figura de grande respeito e admiração, ajudando os amigos e também a população romana em casos de necessidade. Uma de suas amigas, também, beneficiada por seu apoio foi Urgulânia: em um conflito com Lúcio Pisão, que pediu que esta fosse citada em juízo, ela permaneceu na casa de Lívia, que se queixou do desrespeito a sua pessoa com a insistência de Lúcio Pisão. Tibério condescendeu com sua mãe a ponto de ir ele próprio ao tribunal do pretor para ajudá-la. Ao fim, a quantia requerida foi paga a Pisão ${ }^{187}$.

Muito mais do que proteger os amigos, Augusta serviu de barreira aos ataques contra Agripina, logo após sua ida para Roma a situação continuou conflitante e seus amigos sofreram ataques. Por mais que se alegasse que ela e a mãe do imperador se odiassem e a relação com a morte de Germânico, anteriormente exposta, Augusta cuidou de seus filhos, pelo menos três deles, e considera-se que apenas depois de sua morte o pior ataque a ela teria sido feito ${ }^{188}$.

A morte do filho de Tibério, Druso, deixou a casa do César com quatro viúvas: Augusta, Antônia Menor, Agripina Maior e Livila - a viúva de seu filho e irmã de Germânico e Cláudio ${ }^{189}$. O trecho a seguir mostra que antes de Tibério decidir por novamente retirar-se de Roma, um fato importante envolvendo sua mãe ocorre, sendo inclusive citado como um dos principais motivos para seu exílio. Augusta pede ao seu filho que inclua na lista de jurados um homem recentemente feito cidadão, Tibério responde que apenas o faria caso constasse nos registros quer ele fez obrigado pela mãe.

Mais tarde, ele chegou ao ponto de inimizade aberta e a razão, dizem, foi essa: Ela o incitou, diversas vezes, a nomear entre os jurados um homem que tinha sido feito cidadão; ele declarou que apenas iria fazê-lo desde que ela permitisse constar na lista oficial como isto sendo feito forçado por ela. Em seguida, Lívia, em um acesso de raiva, tirou de um lugar secreto e leu algumas cartas antigas e escritas para ela por

\footnotetext{
${ }^{186}$ Tac. Ann. 2, 82, 2.

187 Tac. Ann. 2, 34.

188 Informações sobre ataques contra Agripina e seus amigos em Suet. Tib. 52, 3; 53; $61,1$. Tac. Ann. 4, 17, 4; 19, 1-2; 39, 6; 40, 3-4; 52; 53; 54, 2-5; 5, 3, 1-2; 6, 25, 1; 26, 4. BARRETT, Anthony A. (2002). op. cit., p. 129. ROGERS, Robert Samuel (1931). TAPhA, p. 143-146, 157. SHOTTER, David C. A. Historia, p. 351-352, 354.

${ }^{189}$ BARRETT, Anthony A. (2002). op. cit., p. 94.
} 
Augusto, que diziam respeito à austeridade e teimosia do temperamento de Tibério. Ele por sua vez estava tão desconcertado com estas cartas que foram preservadas por tanto tempo e foram atiradas a ele com um espírito tão vingativo, que alguns pensam que esta era a mais forte razão para seu exílio. De qualquer forma, durante os três anos que ela viveu - depois que ele partiu de Roma - a viu apenas uma vez, apenas um dia, por poucas horas; quando, pouco depois ela ficou doente e ele não se apressou para visitá-la. Logo ela morreu e após um atraso de vários dias, durante os quais ele [Tibério] manteve a esperança de sua chegada, ela havia sido finalmente enterrada, pois a condição do corpo tornou isto necessário; ele proibiu sua deificação, alegando que estava agindo de acordo com suas próprias instruções. Ele ainda violou as disposições do seu testamento e dentro de um curto período de tempo causou a queda de todos os seus amigos e pessoas íntimas, mesmo aqueles a quem ela tinha em seu leito de morte confiado os cuidados com seu funeral; na verdade, condenando um deles, que era um homem de posição equestre, aos trabalhos hidráulicos. (Suet. Tib. 51.)

A afirmação que também é feita é que ele foi impulsionado para o exílio pelo temperamento arrogante de sua mãe, cuja parceria em seu poder não poderia tolerar, enquanto era impossível abandonar, pois o tinha por mercê dela. (Tac. Ann. $4,57,4$.)

Os autores, Suetônio e Tácito, apresentam uma Lívia que se valeu de sua posição materna e a possível influência exercida sobre Augusto na adoção de Tibério, para reivindicar a participação no governo. Tendo seus pedidos negados - os que diziam respeito a assuntos políticos -, ela agiu de forma a deixar claro ao filho (e imperador) que Augusto tinha dúvidas com relação a ele e é provável que tenha servido, também, como comprovação que sua intervenção havia sido fundamental para que Tibério viesse a ser o imperador. Assim como anteriormente exposto no excerto que trata da adoção de Tibério 190 .

Pouco antes de realizar esta breve visita a sua mãe, destacada na citação anterior, outro fato pode ser destacado no convívio entre mãe e filho e o possível desejo de poder de Augusta. Em uma efígie próxima ao Teatro de Marcelo, dedicada a Augusto e realizada por ela, na inscrição o nome da matrona aparece antes do nome do imperador ${ }^{191}$.

\footnotetext{
${ }^{190}$ Tac. Ann. 4, 57, 5.

191 Tac. Ann. 3, 64, 2.
} 
O comportamento de Tibério na morte de sua mãe foi tido como um sinal de como a relação familiar deles estava abalada; durante a morte de seu irmão e de seu pai adotivo ele viajou buscando encontrá-los ainda vivos. A atitude de não ir de encontro com a já falecida mãe, mesmo deixando a entender que o faria, fez com que o imperador fosse aguardado até que as condições do corpo não mais permitissem. Ela foi enterrada com uma cerimônia simples e tendo os elogios fúnebres realizados por seu bisneto Calígula. Os funerais de Otávia e de Augusta foram bem destoantes; Otávia teve elogios feitos pelo seu irmão e também pelo genro Druso, filho de Lívia ${ }^{192}$. Todavia, Suetônio deixa claro em seu texto que Augusta deixou as providências de seu velório definidas em seu leito de morte.

Logo ele irrompeu em toda forma de crueldade, já que nunca Ihe faltava ocasião: perseguia os amigos e até os conhecidos, primeiro de sua mãe, em seguida, de seus netos e nora, e, finalmente, de Sejano. (Suet. Tib. 61, 1)

Em qualquer caso, seguiu-se doravante um despotismo puro e opressivo. Enquanto Augusta ainda era viva, havia permanecido um refúgio, uma vez que a deferência à sua mãe estava arraigada em Tibério e nem Sejano se aventurou a reivindicar precedência sobre a autoridade de um parente. Mas agora, como se libertados do controle, irromperam sem restrições. Uma carta denunciando Agripina e Nero foi enviada a Roma; a impressão generalizada é que ela foi entregue muito antes e suprimida pela anciã matrona, uma vez que foi lida publicamente não muito tempo depois de sua morte. (Tac. Ann. $5,3,1-2)$

Após a morte da matrona a barreira que ela representava a agressões e ofensas contra a família e amigos finalmente cessou e ataques ocorreram contra seus amigos e contra Agripina e sua família: Plancina cometeu suicídio; Agripina Maior e seu filho Nero foram banidos e mais tarde outro de seus filhos, Druso, teve o mesmo destino. Galba, o futuro imperador que teve apoio de Augusta e era herdeiro dela, teve o valor destinado a ele reduzido por Tibério ${ }^{193}$. Independente de qualquer queda de popularidade durante o julgamento de Plancina, Augusta foi uma mulher influente que se manteve agindo de acordo com as atribuições doméstica; para ela foram oferecidas diversas honras, que mesmo não sendo aceitas por Tibério representam sua grande relevância,

\footnotetext{
192 BARRETT, Anthony A. (2002). op. cit., p. 216. GRETHER, Gertrude. AJP, p. 237.

193 Tac. Ann. 6, 26, 4. Suet. Tib. 53, 2. Calig. 10, 1. Galb. 5, 2.
} 
como destaca o próximo excerto; assim como ela foi usada na propaganda augustana e continuará sendo utilizada por Calígula e Cláudio, tendo o dia de seu aniversário comemorado e estátuas difundidas ao longo do império ${ }^{194}$. A recusa de Tibério não impediu que senadores admiradores dela se referissem informalmente a ela como mater patriae ${ }^{195}$.

Suetônio mostra algumas passagens em que o comportamento de Lívia não é apenas de uma mulher da família, uma mãe apenas. Ela tinha poder o bastante para influenciar o jogo político, atuava publicamente (como o caso do incêndio) e até o fim de seus dias serviu como uma barreira para ataques a membros da família que ela formou junto de Augusto, a domus Augusta. Algumas dessas passagens, especialmente a da questão do incêndio em Roma são referentes ao período de governo de Augusto e agora ela é representada não apenas como a esposa adequada que não interferia e sim como uma mulher que interferiu em uma esfera masculina ${ }^{196}$. Pensando na quantia deixada por ela para o futuro imperador Galba, o valor de cinquenta milhões de sestércios - e ele não era o único de seus herdeiros ${ }^{197}$-, sabemos que ela tinha uma considerável fortuna; ela possuía propriedades na Ásia Menor e no Egito e minas na Gália ${ }^{198}$. Também participou de uma atividade popular, a salutatio, recebendo os cumprimentos em sua casa, Dion Cássio informa que este evento entrou para os registros públicos ${ }^{199}$. Assim como destacado a seguir pela autora Emily Ann Hemelrijk, sua fortuna e influência a colocavam em uma posição de poderosa patrona, especialmente para questões políticas:

(...) Lívia, que por causa de sua grande riqueza e sua posição de destaque como a esposa e a mãe do imperador reinante era uma patrona poderosa em questões políticas, e que, além

\footnotetext{
${ }^{194}$ Honras divinas para Augusta em Suet. Claud. 11, 2. Uso de Augusta nas propagandas do neto e do bisneto, uma forma de destacar-se como parte da domus Augusta em BARRETT, Anthony A. (2002). op. cit., p. 222-223. ERHART, K. Patricia. A New Portrait Type of Octavia Minor. JPGMJ, v. 8, 1980, p. 117.

${ }_{195}$ DIXON, Suzanne (1990). op.cit., p. 97.

${ }^{196}$ PRYZWANSKY, Molly M. op. cit., p. 126-127.

197 Suet. Galb. 5, 2.

${ }^{198}$ Listagem das propriedades e outros bens possuídos por Lívia em BARRETT, Anthony A. (1996). op. cit., p.181-182.

${ }^{199}$ Dio Cas. Hist. 57, 12, 2.
} 
disso, era conhecida por construções de prédios públicos e por suas atividades filantrópicas. ${ }^{200}$

A relação entre mãe e filho pode ter sido afetada nos últimos anos da vida de Lívia, mas é sabido que Tibério reconhecia sua importância e acatou alguns de seus requerimentos; entretanto devemos pensar que as atitudes dela, suas participações públicas e seu comportamento - mesmo sem receber nenhum poder como o imperium - serviram como modelo para as mulheres da família e para as mulheres romanas no geral. Os autores antigos Dion, Tácito e Suetônio descrevem-na como detentora de poder e embora ela abertamente confinava-se na esfera feminina, cruzou a linha divisória dos gêneros, todavia nunca desrespeitando a moral romana ${ }^{201}$. Agora, havia uma corte imperial e dentro desta intrigas políticas afloravam e especialmente o embate com Agripina Maior demonstra isso. Após a morte de Tibério, Calígula ascende ao poder, e junto a ele estavam suas três irmãs e todas as lembranças da perseguição contra sua família.

\subsection{As relações de poder na corte: as mulheres da domus Augusta durante o fim do principado de Tibério e o principado de Calígula}

Pouco depois de impedir a destruição da ponte do Reno, Agripina Maior deu a luz a sua primeira filha, Agripina Menor - sendo este bebê o quarto filho do casal. Já com pouco mais de um ano de vida Agripina Menor esteve em Roma pela primeira vez, em uma ocasião muito especial e de extrema importância para os acontecimentos que se seguiram: Germânico retornou da Germânia com sua esposa e mais cinco filhos celebrando seu triunfo pelas vitórias sobre as tribos do ocidente de Elba ${ }^{202}$.

Para os espectadores, o efeito foi agravado pela nobre figura do próprio comandante e pelos cinco filhos que carregava em seu carro. No entanto, abatido por um medo silencioso, os

\footnotetext{
${ }^{200}$ HEMELRIJK, Emily Ann. Matrona docta: educated women in the Roman élite from Cornelia to Julia Domna. London : Routledge, p. 113-114.

${ }_{201}$ DIXON, Suzanne (2007). op.cit., p. 110-112, 118.

${ }^{202}$ BARRETT, Anthony A. (1996). op. cit., p.29-30.
} 
homens refletiram que a seu pai Druso o favor da multidão não havia trazido felicidade; que Marcelo, seu tio, ainda jovem havia capturado os afetos ardentes do povo. Aqueles amores da nação romana eram fugazes e desventurados! (Tac. Ann. 2, 41, 4-5.)

Os pontos principais deste trecho são o forte carinho que a população romana nutria por Germânico e especialmente a presença das crianças no triunfo, atitude que Augusto já havia realizado ${ }^{203}$. Mais uma vez vinculava-se a vitória militar e a família, no caso um matrimônio fértil. Após este triunfo Germânico foi enviado para negociar com os Partas a situação dos Armênios. De seus cinco filhos, apenas Calígula acompanhou o pai e a mãe nessa nova jornada, os outros possivelmente permaneceram junto ao tio Cláudio, pois Druso (filho do imperador Tibério) encontrava-se em campanha ${ }^{204}$. O reencontro da família ocorreu quando Agripina Maior retornou com as cinzas de seu marido, tendo em sua recepção mais uma prova da fama e carinho que adquiriram:

Druso veio até Terracina com o irmão de Germânico, Cláudio, e as crianças que tinham sido deixadas na capital. Os cônsules, Marco Valério e Marco Aurélio (que já tinha começado a sua magistratura), o Senado e uma parte considerável de pessoas, preencheram a estrada, de pé em partes dispersas e chorando à vontade; para a adulação não havia ninguém, uma vez que todos os homens sabiam que Tibério estava com dificuldade de dissimular sua alegria com a morte de Germânico. (Tac. Ann. 3, 2, 4-5.)

O excerto confirma que algumas das crianças do casal estavam na capital junto de outros parentes e ainda as coloca na cena de recepção da mãe e das cinzas do pai. Ainda temos senadores e população aguardando a chegada da viúva e o historiador deixa claro que Tibério encontrava-se feliz com a morte do filho adotivo. A viúva e o imperador, a partir de então, terão cada vez mais animosidades em sua relação familiar.

Agripina Maior contava com relevantes apoiadores, com o carinho da população romana e, especialmente, com a certeza de sua ascendência superior. Por volta do ano de 24 , Sejano encorajava as suspeitas sobre ela possuir um grupo de fortes apoiadores, isso porque naquele ano nos votos

\footnotetext{
${ }^{203}$ Ponto anteriormente abordado na página 54 desse trabalho.

${ }^{204}$ BARRETT, Anthony A. (1996). op. cit., p.29.
} 
para a segurança do príncipe foram incluídos os dois filhos mais velhos dela, Nero e Druso - Tácito declara que isto ocorreu graças à ação de aduladores. ${ }^{205}$

A verdade é que Sejano estava pressionando ele [Tibério] muito: - "O Estado", então passou a acusação, "foi dividido em duas partes, como em uma guerra civil. Nele há homens que se proclamaram do partido de Agripina: a menos que uma posição seja tomada, vão existir mais; e a única cura para a crescente desunião é derrubar um ou dois dos descontentes mais ativos." (Tac. Ann. 4, 17, 4.)

Toda a pressão exercida por Sejano deu início a uma série de ataques a amigos de Agripina. O primeiro ataque ocorreu contra Caio Sílio e sua esposa Sósia Gala; ele tinha sido legatus na Germânia e ela estava com Agripina durante a fuga do acampamento após a morte de Augusto. O casal tinha relevância, foram acusados de fazer uma aliança com famílias na Gália que tinham um vínculo passado com Júlio César - ele tinha sido patrono de alguns ascendentes destas e a lealdade passou aos seus descendentes. Agripina possivelmente teria relembrado essa lealdade e a aliança teria ajudado Sílio a enriquecer. Por fim, Sílio cometeu suicídio e sua esposa foi exilada. ${ }^{206}$

\begin{abstract}
Enquanto isso Agripina, obstinadamente aumentava sua raiva e atacada por uma doença física, foi visitada pelo César. Por muito tempo as lágrimas caíram em silêncio e depois, ela começou com acusações e súplicas. "Ele deve curar sua solidão e dar-lhe um marido; ela tinha ainda a juventude necessária e os virtuosos não tinha consolo se não no casamento, os cidadãos romanos se curvariam para receber a esposa de Germânico e seus filhos". O César, no entanto, embora vendo tudo que estava implícito no pedido, estava relutante em trair seu medo ou seu ressentimento e, portanto, apesar da insistência, deixou sem resposta. - Este incidente, não observado pelos professos historiadores, eu encontrei nas memórias de sua filha Agripina (mãe do imperador Nero), que registrou para posteridade as vicissitudes de sua casa. (Tac. Ann. 4, 53)
\end{abstract}

\footnotetext{
${ }^{205}$ Sobre a inclusão dos nomes de Nero e Druso nos votos. Tac. Ann. 4, 17.1. Informações das ações de Sejano contra Agripina. BARRETT, Anthony A. (1996). op. cit., p.33. ROGERS, Robert Samuel. TAPhA, p. 151. SHOTTER, David C. A. Historia, p. 349-350.

${ }^{206}$ Ataques aos amigos de Agripina Maior, Caio Sílio e Sósia Gala em Tac. Ann. 4, 18-20. BARRETT, Anthony A. (1996). op. cit., p.34. ROGERS, Robert Samuel. TAPhA, p. 141-143. SHOTTER, David C. A. Historia, p. 351.
} 
Neste trecho, Tácito faz uso de uma fonte que, infelizmente, não chegou até os dias atuais. Faz uso de uma suposta biografia de Agripina Menor, um livro escrito pela própria que registrava provavelmente a história de sua família, em última instância mais uma forma de mostrar sua ligação com Augusto. O casamento de Agripina Maior foi recusado, pois se supunha que seria com 0 senador Asínio Galo. Tibério poderia ter ressentimentos com ele devido ao casamento com Vipsânia, logo após seu divórcio para casar-se com Júlia. Entretanto o senador, durante os questionamentos sobre o cargo que Tibério assumiria, logo após a morte de Augusto, perguntou abertamente a ele qual magistratura escolheria; Galo resumiu sua fala dizendo que não desejava que Tibério dividisse o indivisível, mas que ele próprio dissesse que o corpo político era um organismo uno e que era governado por uma única mente. Posteriormente, Asínio Galo também foi perseguido por Tibério provavelmente por seu envolvimento com Agripina Maior - e condenado, morrendo após três anos de exílio ${ }^{207}$.

O trecho a seguir de Suetônio apresenta Agripina acusando Tibério de atacar seus amigos, citando o caso de Sósia Gala e o caso que a fez visitá-lo, de Cláudia Pulcra.

Agripina - com seu temperamento violento de sempre e agora inflamada pelo perigo de sua parenta ${ }^{208}$ - foi até Tibério e, como acaso quis, encontrou-o realizando um sacrifício para seu pai. Isto deu a oportunidade para uma explosão de reprovação: "Não é este", disse ela, "o mesmo homem que oferece vítimas ao Divino Augusto e persegue a sua posteridade? Não é por meio de pedras sem fala que havia sido transmitido aquele espírito divino: ela, a sua efígie autêntica, descendente de seu sangue celestial, estava ciente de seu perigo e assumia o traje de luto. Foi necessário usar como pretexto Pulcra, cuja única causa de sua destruição foi a de que levianamente ela tinha escolhido Agripina como o objeto de sua afeição, esquecia-se de Sósia, que foi derrubada pelo mesmo crime". As palavras dela suscitaram uma das raras declarações daquele coração impenetrável. Ele a segurou e advertiu em um verso em grego que ela não era necessariamente "a mulher ferida, se ela não reina". (Tac. Ann. 4, 52, 3-7.)

\footnotetext{
${ }^{207}$ Sobre o desentendimento de Asínio Galo e Tibério no Senado, assim como o casamento do primeiro com Vipsânia. Tac. Ann. 1, 12. Informações da perseguição contra Asínio Galo e seu envolvimento com Agripina Maior. BARRETT, Anthony A. (1996). op. cit., p. 35; 46. ROGERS, Robert Samuel. TAPhA, p. 155; 161-163. SHOTTER, David C. A. Historia, p. 353.

${ }^{208}$ Cláudia Pulcra, prima de Agripina em segundo grau.
} 
Cláudia Pulcra foi levada a julgamento por adultério e por tentar envenenar o imperador; ela era prima em segundo grau de Agripina Maior e uma de suas melhores amigas. A viúva tomou este ataque como se fosse contra si mesma e procurou o imperador para questioná-lo, relembrando-o mais uma vez sua descendência biológica de Augusto e acusando-o de perseguir a própria família. Provavelmente esta discussão ocorreu após a tentativa de Agripina Maior realizar um novo matrimônio. A partir desse evento o imperador e a viúva não mantêm mais nenhum tipo de contato familiar, como jantares, conversas, festas, entre outros ${ }^{209}$.

Outra situação de destaque entre eles é mostrada por Suetônio.

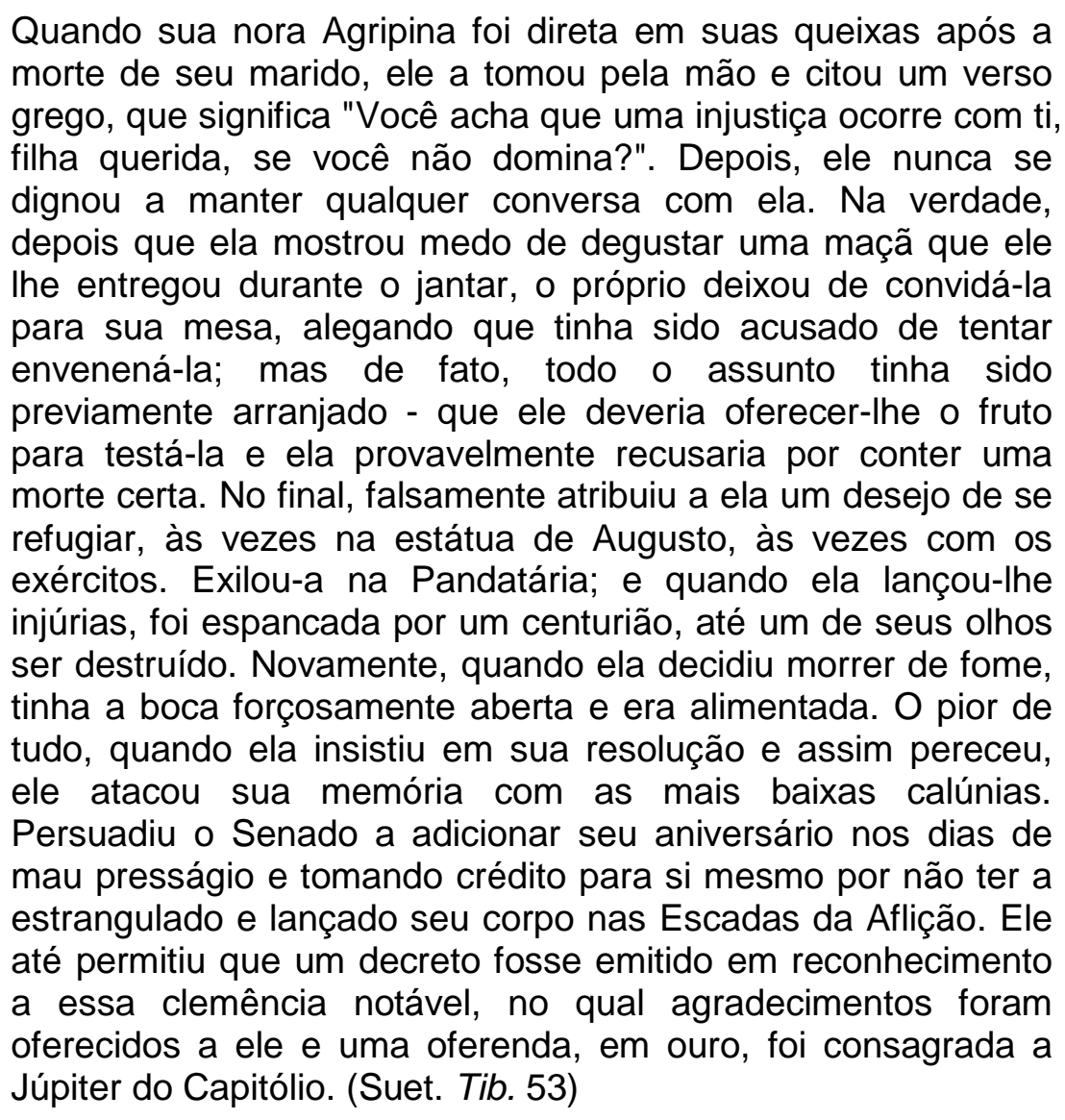

A situação entre o imperador e Agripina Maior, em seus momentos finais, demonstra especialmente que Tibério a acusava diretamente de desejar exercer o poder; ela como descendente biológica de Augusto era uma oponente ao poder. Uma mulher romana baseada em suas ascendências

${ }^{209}$ BARRETT, Anthony A. (1996). op. cit., p.35. ROGERS, Robert Samuel. TAPhA, p. 153-154. SHOTTER, David C. A. Historia, p. 351. 
compreendeu que era direito seu estar ligada ao poder; não podemos afirmar que ela desejava o poder para si própria ou para um de seus filhos. Entretanto é inegável que sua ligação biológica com Augusto foi relembrada e utilizada para justificar suas atitudes e aspirações.

Posteriormente à morte de Augusta, os ataques finais foram feitos a Agripina Maior e seus dois filhos mais velhos, que anteriormente haviam sido vinculados aos supostos planos maternos de chegar ao poder ${ }^{210}$. Os outros filhos permaneceram aos cuidados de Augusta e depois de sua avó Antônia Menor. Calígula, Drusila, Livila e Agripina Menor não sofreram diretamente com os ataques a sua família, assim como Agripina Maior não havia sido afetada com os banimentos de sua mãe e irmã. Em seus questionamentos com Tibério durante os acontecimentos envolvendo Cláudia Pulcra, Agripina Maior o acusou de atentar contra a família de Augusto. Exílios de familiares já haviam ocorrido na domus Augusta, o próprio Augusto baniu sua filha Júlia, a neta Júlia II e o neto e também filho adotivo Agripa Póstumo. Isto ocorreu porque os envolvidos possivelmente tramaram contra o imperador ou relacionaram-se com pessoas que representavam uma ameaça ao poder vigente ${ }^{211}$.

A existência de casos anteriores de exílios na família de Agripina Maior justifica em parte os outros filhos não terem sido diretamente afetados pelo que ocorreu à mãe e aos irmãos. Antes da intensificação das animosidades entre Tibério e Agripina Maior, seus filhos mais velhos tiveram suas carreiras impulsionadas pelo imperador e permaneceram morando com Druso - filho de Tibério - mesmo quando os filhos gêmeos dele nasceram ${ }^{212}$. Agripina Menor também foi pauta dos assuntos do imperador Tibério; ele escolheu seu primeiro marido e pai biológico do futuro imperador Nero.

Quanto ao resto, Tibério, depois de pessoalmente conferir a Cneu Domício a mão de sua neta Agripina, ordenou que o casamento fosse celebrado em Roma. De Domício, para não falar da antiguidade da sua família, haviam escolhido um conexão com o sangue dos Césares; porque ele podia se gabar de Otávia como sua avó, e através dela, Augusto como seu tio-avô. (Tac. Ann. 4, 75.)

\footnotetext{
${ }^{210}$ Ataques finais feitos contra Agripina Maior e filhos que ocorreram logo após a morte de Augusta. Tac. Ann. 5, 3, 1. BARRETT, Anthony A. (1996). op. cit., p.38.

211 ROGERS, Robert Samuel. TAPhA, p. 146-149.

212 Informações sobre o relacionamento familiar e as carreiras dos filhos mais velhos de Agripina Maior, Nero e Druso em Tac. Ann. 4, 8. BARRETT, Anthony A. (1996). op. cit., p.32.
} 
A escolha de Tibério seguiu a mesma direção das escolhas de Augusto com os casamentos endogâmicos. Domício era filho de Antônia Maior, filha de Marco Antônio e Otávia. Neste casamento Agripina Menor deu a luz a seu único filho que viria a ser o último imperador da dinastia Júlio-Claudiana e que também poderia orgulhar-se da descendência de Otávia e Augusto. É necessário destacar que durante os eventos que levaram ao banimento de seus familiares Agripina Menor encontrava-se morando com seu marido, distante dos conflitos ${ }^{213}$.

Da família de Agripina Maior e Germânico apenas as filhas e Calígula sobreviveram. Toda essa situação com a família provavelmente deixou os irmãos próximos e já sob o principado de Calígula as irmãs receberam muitas honras. Elas receberam os mesmos direitos das Virgens Vestais, como poder gerir seus bens sem um tutor e se sentarem em lugares diferenciados nos eventos públicos. Elas foram representadas junto do irmão nas moedas e as cinzas da mãe e do irmão Nero colocadas no Mausoléu de Augusto - os restos mortais de Druso não foram encontrados. Calígula teria feito algumas ofensas a sua bisavó Augusta, mas fez cumprir seu testamento e relembrou sua origem familiar em representações e homenagens aos pais mortos. Muito além de recuperar a imagem da mãe e dos irmãos, assim como relembrar o parentesco com Augusto, Calígula colocou suas irmãs ao seu lado em importantes momentos de seu governo ${ }^{214}$. Isto é destacado no trecho a seguir de Suetônio, a inclusão do nome de suas irmãs nos juramentos.

Ele fez com que os nomes de suas irmãs fossem incluídos em todos os juramentos: "Caio e suas irmãs tão caros como eu e meus filhos", bem como nas proposições dos cônsules: "Graças e boa fortuna compareçam a Caio César e suas irmãs." (Suet. Calig. 15, 3)

\footnotetext{
${ }^{213}$ BARRETT, Anthony A. (1996). op. cit., p. 37-38; 44-46.

${ }^{214}$ Calígula fez cumprir o testamento de Augusta. Suet. Calig. 16, 3. Sobre o uso das mulheres como parte das propagandas dos sucessores de Augusto de forma a reafirmar-se como parte da domus Augusta. BARRETT, Anthony A. (1996). op. cit., p.53-54. SMITH, Cecil H. Burl.Mag., p. 100. ROGERS, Robert Samuel. TAPhA, p. 168. WOOD, Susan. Memoriae Agrippinae: Agrippina the Elder in Julio-Claudian Art and Propaganda. AJA, v. 92, n. 3, 1988, p. 410-415. FANTHAM, Elaine, et al. Women in the Classical World: Image and Text. New York: Oxford University Press, 1995, p. 312-313. LEVICK, B. 'Julians and Claudians'. G\&R, Second Series, v. 22, n. 1 (Apr., 1975), p. 36.
} 
A vida familiar permaneceu pacifica até o nascimento de Nero, filho de Agripina Menor. Durante a escolha de seu nome - Lúcio Domício Enobarbo -, supostamente Agripina teria pedido a Calígula que sugerisse um nome para seu filho e ele teria indicado Cláudio ao olhar para o tio ${ }^{215}$ - uma figura da família que era constante motivo de chacota ${ }^{216}$. Por mais que a figura de Cláudio fosse mal vista, durante o principado de Calígula ele viveu em harmonia com a família. Agripina Menor provavelmente recusou a oferta, ou mesmo se ofendeu, pois caso acatasse a sugestão haveria no nome do infante um vínculo com a família Cláudia - ou seja, uma ligação com Tibério ${ }^{217}$.

Depois da morte de Drusila, com quem Calígula tinha um convívio mais próximo e foi até mesmo acusado de incesto, a harmonia familiar teve fim. $\mathrm{O}$ viúvo de sua irmã, Marco Emílio Lépido, envolveu-se com as duas irmãs ainda vivas. Até então, Calígula não tinha descendentes e a boa relação com o imperador fazia de Lépido um candidato à sucessão. Envolver-se com uma das irmãs do imperador e que também estavam associadas ao governo deixava Lépido em uma situação ainda mais favorável, especialmente com Agripina após o nascimento de seu filho. Depois do casamento do Calígula com Cesônia - uma mulher com fertilidade comprovada, tendo já três filhos e casando-se grávida de uma quarta cuja paternidade Calígula assumiu -, as prováveis intenções de Agripina, Livila e Lépido de chegar ao poder encontraram uma barreira. Tensões entre o imperador e os senadores e tensões com os comandos militares são registrados nesse momento em seu governo; caso Lépido se casasse com uma das irmãs e chegasse ao poder (a outra teria seus privilégios e status naturalmente reduzidos) o vínculo com Augusto e Germânico ainda seria mantido. Independentemente dos motivos dos conspiradores, o resultado do julgamento foi o exílio e perda ${ }^{218}$ dos bens para as irmãs e a morte de Lépido; Agripina, antes do exílio, teve que levar para Roma com os restos mortais de seu amante. ${ }^{219}$

\footnotetext{
${ }^{215}$ Suet. Nero. 6, 1.

${ }^{216}$ Ponto anteriormente exposto nas páginas 45-46 desse trabalho.

${ }^{217}$ BARRETT, Anthony A. (1996). op. cit., p. 57.

${ }^{218}$ Os bens foram vendidos por Calígula na Gália. Suet. Calig. 39.1.

${ }^{219}$ Informações sobre o envolvimento das irmãs de Calígula com Lépido em Suet. Calig. 25, 3; Claud. 9, 1. Tac. Ann. 14, 2, 3. Dio Cas. Hist. 59,18-23. BARRETT, Anthony A. (1996). op. cit., p.62-70.
} 
Viveu em incesto habitual com todas as suas irmãs; e em um grande banquete colocou-as alternadamente em baixo dele, enquanto sua esposa ficava em cima. Destas [suas irmãs], acreditava-se que ele teria violado Drusila quando ainda envergava a toga pretexta, até mesmo teria sido apanhado deitado com ela por sua avó Antônia, em cuja casa eles foram criados juntos. Depois, quando ela já era a esposa de Lúcio Cássio Longino, um ex-cônsul, tomou dele e abertamente a tratou como sua legítima esposa. Na época que esteve doente, a fez herdeira de seus bens e do trono. Quando ela morreu, ele nomeou um período de luto público, durante o qual era uma ofensa capital rir, tomar banho ou jantar na companhia de seus pais, esposa ou filhos. Ele estava tão fora de si com a tristeza que, de repente, fugiu da cidade durante a noite e atravessou a Campânia, foi para Siracusa e apressadamente voltou de lá sem cortar o cabelo ou raspar a barba. Depois, quer em relação aos os negócios mais importantes, ou mesmo diante da assembléia do povo e na presença dos soldados, nunca pronunciou um juramento que não fosse pela divindade de Drusila. O resto de suas irmãs não amou com tão grande afeto, nem concedeu honras tão altas, mas muitas vezes as prostituiu com seus favoritos. Dessa forma, ele era o mais preparado para o julgamento de Emílio Lépido, para condená-las como adúlteras e cúmplices das conspirações contra ele; e não apenas fez cartas abertas manuscritas sobre todos eles, proscritos por fraudes e sedução, mas também dedicou para Marte o Vingador - com uma inscrição explicativa - três espadas preparadas para tirar sua vida. (Suet. Calig. 24)

As constantes acusações de incesto não podem ser comprovadas, mas novamente temos as mulheres da família de Augusto sendo exiladas por se relacionarem com pessoas que poderiam representar ameaças ao poder. Calígula e as irmãs sobreviveram à crise no principado de Tibério e permaneceram unidos nos primeiros momentos - possivelmente um reflexo das perdas familiares que haviam passado. Entretanto foram criados com a clara ideia de que eram descendentes do sangue de Augusto e que o lugar que deveria ser deles, e pelo qual a mãe havia morrido lutando, estava nas mãos de outra pessoa. Deixando de lado estas possíveis conspirações pelo poder, todos eles foram criados em uma corte em que sua origem era destacada e as intrigas eram constantes.

Nós podemos supor que como uma das crianças de Germânico ela foi bem educada. Nós também podemos supor em sua juventude ela teria aprendido com sua mãe uma forte certeza de seu importante lugar no esquema das coisas, um local destinado a ela como uma filha do aclamado Germânico e de Agripina Maior, a última neta sobrevivente de Augusto. Os destinos infelizes de sua mãe e irmãos também teriam Ihe 
ensinado a necessidade de cautela e diplomacia nas questões políticas, um princípio que manteve em sua vida e que ela iria negligenciar uma única vez, com resultados desastrosos, quando teve que lidar com seu próprio filho. ${ }^{220}$

A forte imagem da mãe provavelmente fez com que suas filhas considerassem a ideia de uma participação mais efetiva, ou de buscarem parcerias e contatos para alcançarem seus objetivos. O que justificaria 0 envolvimento de Livila e Agripina Menor nas conspirações contra o irmão Calígula. Especialmente Agripina Menor - que ocupa importante posição nos próximos eventos do império - aprendeu como se colocar nas disputas pelos poder e lidar com as intrigas palacianas utilizando-se de valiosos aliados, tornando-se, assim, esposa do sucessor de seu irmão e ajudando seu filho a chegar ao poder.

${ }^{220}$ BARRETT, Anthony A. (1996). op. cit., p.41. 


\section{Agripina Menor: uma mulher consciente da dinâmica da domus Augusta}

Durante o principado de Calígula, suas irmãs foram muito honradas a princípio; com a morte de Drusila os conflitos palacianos afloraram e novas perseguições dentro da própria família ocorreram. Agripina Menor e a irmã Livila sofreram condenações por adultério, com o cunhado Marco Emílio Lépido, e por tramar contra o imperador e irmão. Junto delas, Sêneca e outras pessoas foram condenados por associarem-se as irmãs ${ }^{221}$. Durante o principado de Cláudio estes condenados receberam a permissão de retornar para Roma e alguns farão novamente parte do jogo político.

Muitas novas acusações serão feitas contra essas duas mulheres, especialmente Agripina tem nas fontes primárias mais destaque e uma visão muito negativa. Tácito a descreve como uma mulher que era apaixonada por dinheiro e que só agia de forma lasciva para obter poder, que todos seus atos eram pautados por esta busca. Então, Agripina Menor é descrita em situações de grande relevância, mas sempre em busca de destacar-se e obter poder.

Suetônio também possui uma visão negativa de Agripina, mas ele não esmiúça suas ações como Tácito; o autor destaca mais sua relação familiar com Cláudio e Nero, sem detalhar quem eram os aliados e libertos dentro do palácio. Mesmo com estas visões negativas, podemos notar muito da influência desta mulher nas Vidas e como ela soube lidar com as intrigas e boatos palacianos.

Agripina Menor foi irmã de um imperador e no período inicial deste governo possuiu grande destaque, exaltando a figura da mãe Agripina Maior, do pai Germânico e especialmente de Augusto. Este destaque de sua origem nobre contribuiu para a relevância de seu casamento com o novo imperador, seu tio Cláudio.

\footnotetext{
${ }^{221}$ Tigelino foi condenado e acusado de se relacionar com Agripina Menor. Ele irá ocupar o cargo de chefe da guarda pretoriana no principado de Nero, após a morte de Agripina. ROPER, Theresa K. Nero, Seneca and Tigellinus. Historia, v. 28, n. 3 (3rd Qtr., 1979), p. 346.
} 


\title{
4.1 O retorno do exílio: o segundo casamento e os conflitos na corte imperial
}

As irmãs, Agripina Menor e Livila, retornaram de seus exílios após o tio Cláudio chegar ao poder. As acusações de adultério que elas haviam recebido provavelmente foram retiradas, pois Livila foi considerada casada com Marco Vinício até a data de sua morte e Agripina pode contrair novos matrimônios seu primeiro marido, Domício, provavelmente faleceu no ano de 40 ou 41. Agripina recebeu à herança dele, reduzida pelos gastos de Calígula; e ainda, recuperou o filho que se encontrava sob os cuidados da tia Domícia ${ }^{222}$.

A primeira possibilidade de matrimônio para Agripina é mostrada por Suetônio. O homem em questão era Galba, o futuro imperador.

\begin{abstract}
Ele se dedicou as leis, bem como a outros estudos liberais. Igualmente dedicou-se ao matrimônio; mesmo depois da morte de sua esposa Lépida e dos dois filhos que tiveram, ele permaneceu viúvo. E ele não foi tentado por nenhuma união posterior, nem mesmo Agripina, que não muito após a perda de Domício tentou obviamente conquistar Galba, antes mesmo da morte da esposa dele. A mãe de Lépida, junto de um grupo de matronas, a repreendeu severamente e foi tão longe a ponto de esbofeteá-la. (Suet. Galb. 5, 1)
\end{abstract}

Agripina é apresentada por Suetônio nesse trecho como uma mulher que tentou conquistar um homem casado. Galba era uma excelente opção, pois era membro de uma relevante família, um militar de destaque e ainda tinha contado com a ajuda de Lívia em sua carreira (além da herança deixada por ela); porém, ele não se deixou levar pelas investidas de Agripina - que se comportava de forma lasciva, assim como em seu envolvimento com o cunhado Marco Emílio Lépido ${ }^{223}$ quando ainda estava casada.

Sobre esta possibilidade de casamento, Barrett comenta que não poderia ocorrer exatamente como Suetônio descreve; o incidente com a mãe de Lépida é descrito como tendo ocorrido pouco depois da morte de Domício.

\footnotetext{
${ }^{222}$ BARRETT, Anthony A. Agrippina: sex, power, and politics in the Early Empire. London: Routledge, 1996, p. 78-79.

${ }^{223}$ Conforme exposto na página 83 deste trabalho.
} 
Nesse período, Agripina ainda estava exilada e Galba se encontrava em campanha militar na Germânia; Barrett considera que se esse envolvimento, ou possível envolvimento, realmente tenha ocorrido foi após a morte de Lépida ${ }^{224}$.

O segundo casamento de Agripina é com Caio Salústio Passieno Crispo 225. O pai adotivo de seu novo marido era Salústio Crispo, um dos conselheiros de Augusto que permaneceu auxiliando Tibério; ele exerceu o cargo de cônsul por duas vezes e ainda foi procônsul da Ásia. Entretanto, Passieno Crispo esteve vinculado à domus Augusta anteriormente: ele foi marido de Domícia ${ }^{226}$ - irmã do primeiro marido de Agripina Menor, filha de Antônia Maior e neta de Otávia. Não se sabe se o divórcio dos dois ocorreu para que ele contraísse matrimônio com Agripina, porém isto ajuda a compreender a animosidade entre as duas mulheres. Crispo morreu poucos anos depois, deixando para Agripina e seu filho Domício uma considerável fortuna ${ }^{227}$. Novamente Agripina é acusada de um comportamento inadequado: ela é acusada de envenenar o marido após a confirmação de que ela e o filho haviam se tornado herdeiros da fortuna ${ }^{228}$. Este período provavelmente foi descrito nos livros perdidos da obra de Tácito e dessa forma não temos a data exata da morte de Crispo nem a causa, entretanto é válido destacar que Agripina é acusada de matar dois maridos envenenados.

Outro ponto importante do principado de Cláudio era a conflituosa relação palaciana. Livila, irmã de Agripina Menor, ao retornar do exílio sofreu uma perseguição de Messalina - esposa do imperador Cláudio. Ela foi acusada de passar muito tempo sozinha com o tio logo no começo de seu governo; Messalina é descrita como tendo inveja de sua grande beleza e, também, por articular seu exílio e sua morte ${ }^{229}$. Entretanto, outra questão deve ser pensada, Livila era casada e ainda sem filhos e seu marido Marco Vinício possivelmente foi considerado um forte candidato ao poder após a morte de Calígula ${ }^{230}$; mais do que conflitos entre as mulheres da família esta questão envolvia diretamente

\footnotetext{
${ }^{224}$ BARRETT, Anthony A. (1996). op. cit., p. 84. BARRETT, Anthony A. (1996). op. cit., p.83.

${ }^{225}$ Suet. Nero. 6, 3

${ }^{226}$ GEER, Russel Mortimer . Notes on the Early Life of Nero. TAPhA, v. 62 (1931), p. 61-62.

227 BARRETT, Anthony A. (1996). op. cit., p.84-86. GINSBURG, Judith. Representing Agrippina: Constructions of Female Power in the Early Roman Empire. Oxford and New York: Oxford University Press, 2005, p.16-17.

${ }_{228}$ JUVENAL. Sátiras. 4, 81 apud BARRETT, Anthony A. (1996). op. cit., p.85.

${ }^{229}$ Dio Cas. Hist. 60, 8, 5.

${ }^{230}$ BARRETT, Anthony A. (1996). op. cit., p.81.
} 
o poder, um risco ao governante vigente que não contava com o favor da adoção na família de Augusto. Livila, assim como sua irmã, era uma descendente de Augusto e contava com a grande fama do pai, especialmente entre a guarda pretoriana.

É provável que Livila tenha sido vítima da tensão geral e da paranóia que cercaram a corte no período após a ascensão [de Cláudio]. Messalina pode ter recebido um papel predominante em sua queda simplesmente para reforçar a tradição de que Cláudio era um tolo inepto que seguiu os ditames de sua esposa. ${ }^{231}$

Outra questão relevante que deve ser considerada mais do que resultado de intrigas palacianas entre as mulheres está diretamente ligada à Agripina Menor:

No entanto, a memória de Germânico o deixou [Nero] com um resíduo de popularidade como o único homem daquele ramo da família. Uma compaixão crescente foi sentia por sua mãe, Agripina, em vista de sua perseguição por Messalina, que sempre havia sido inimiga e agora estava mais implacável que o normal; esta só não inventou crimes e acusações porque se encontrava empolgada por um amor insano. (Tac. Ann. 11, 12, 1)

No trecho de Tácito, temos a descrição de Nero como o único homem descendente de Germânico e ainda uma nova perseguição de Messalina, agora contra Agripina; mesmo sem grandes detalhes o autor descreve esta questão apenas como uma inimizade entre as mulheres. Porém, se observarmos outro trecho, agora de Suetônio, podemos novamente perceber as questões políticas em torno dessas mulheres.

Quando sua mãe [Agripina] retornou do exílio e se reinstalou, ele [Nero] tornou-se tão proeminente devido à influência dela que foi revelado que Messalina - esposa de Cláudio - havia enviado um emissário para estrangulá-lo durante seu cochilo diurno, considerando-o um rival de Britânico. Um adicional a este boato era que o possível assassino foi afugentado por uma cobra que saiu por baixo do travesseiro. $O$ único fundamento para esta narrativa era que havia sido encontrada próxima a sua cama, perto do travesseiro, uma pele de

${ }^{231}$ BARRETT, Anthony A. (1996). op. cit., p.82. 
serpente; no entanto, pela vontade de sua mãe, ele incluiu essa pele em uma pulseira de ouro que usou por muito tempo em seu braço direito. Porém, quando a memória de sua mãe tornou-se odiosa para ele jogou-a fora, posteriormente a procurou em vão. (Suet. Nero. 6, 4)

Nesse excerto Suetônio deixa claro que o filho de Agripina era um rival ao poder, era um concorrente de Britânico - filho de Messalina com Cláudio. Temos ainda a compreensão de que os boatos eram interpretados de forma a estimular essas ideias sobre concorrentes ao poder. Por último, Agripina teria convencido o filho a usar uma espécie de amuleto se valendo desses comentários; era uma forma de valorizar sua própria família colocando seu filho como possível candidato ao poder, isso sem esquecer a ascendência mais nobre do mesmo.

\subsection{Relações de poder com Cláudio: o casamento como forma de vinculo a família de Augusto}

Cláudio ascendeu ao governo de forma inesperada, numa atmosfera tensa, cheia de planos conspiratórios e ressentimento. Declarado imperador pela guarda pretoriana e sem vínculos diretos com Augusto, Cláudio se via em uma complicada situação. Suetônio informa alguns ataques contra ele, especialmente a rebelião do governador da Dalmácia Fúrio Camilo Escriboniano $^{232}$; esta rebelião conquistou apoio de senadores e equestres, porém foi contida rapidamente e contou ainda com grande número de desertores entre os soldados de Escriboniano. Cláudio, num ato claramente conciliador, perdoou os filhos de envolvidos em conspirações e revoltas, assegurando a permanência deles na ordem senatorial ${ }^{233}$.

O imperador buscou relembrar sua origem familiar, seu pertencimento à domus Augusta, dando a sua mãe Antônia Menor o título de Augusta, que ela havia recusado em vida; foram realizados jogos anuais no dia do aniversário de

\footnotetext{
${ }^{232}$ Suet. Claud. 13.

233 BARRETT, Anthony A. (1996). op. cit., p.73-75. MCALINDON, D. Claudius and the Senators. AJPh, v. 78, n. 3 (1957), p. 280-281.
} 
seu pai Druso; seus juramentos sempre eram em nome de Augusto; e ainda, o recebimento de honras divinas foi votado para sua avó Lívia. Nem mesmo Marco Antônio, seu avô materno, foi esquecido e seu aniversário foi comemorado também e destacado por Cláudio por ser no mesmo dia do de seu pai, Druso ${ }^{234}$. Porém, ele não tinha um vínculo real com Augusto; mesmo que boatos relativos à paternidade de Druso tenham existido ${ }^{235}$, Augusto não 0 reconheceu como seu filho. A terceira esposa de Cláudio, Messalina, era neta de Antônia Maior e bisneta de Otávia e Marco Antônio; entretanto o vínculo com Augusto só seria possível com seu quarto matrimônio.

O príncipe foi casado quatro vezes e antes destes havia sido noivo por duas vezes, uma delas com Emília Lépida (bisneta de Augusto), porém foi desfeito quando Júlia II foi banida. Sua primeira esposa foi Pláucia Urgulanila; a segunda esposa era Élia Petina; e mesmo que essas moças fossem pertencentes a renomadas famílias, não eram descendentes de Augusto. $O$ terceiro casamento de Cláudio foi com Valéria Messalina e este terminou após ela ter contraído um novo matrimônio estando ainda casada com o imperador ${ }^{236}$. Suetônio e Tácito informam que o principado de Cláudio estava sob a forte influência de libertos e de suas esposas ${ }^{237}$; entretanto devemos notar que o imperador rejeitou o título de Augusta para sua terceira esposa e permitiu sua execução. Além disso, cinco de seus libertos foram condenados no período de seu governo ${ }^{238}$.

A questão dos libertos durante o principado de Cláudio deve ser pensada, também, na crescente complexidade da administração do império e soma-se a isto o pequeno número de aliados no Senado. Os libertos tinham uma série de obrigações com seus patronos e, assim como os equestres, eles ocupavam alguns cargos na administração imperial como forma de conter as possíveis intervenções senatoriais ocupando esses cargos. Os dois libertos que ganham maior destaque, por sua suposta influência sobre Cláudio, são Narciso e Palas. O primeiro é destacado por seu papel na execução de Messalina e ocupava o cargo de ab epistulis, cuidando da correspondência

\footnotetext{
${ }^{234}$ Suet. Claud. 11, 2-3.

235 Anteriormente tratado nesse trabalho na página 38.

${ }^{236}$ Suet. Claud. 26, 2.

${ }^{237}$ Suet. Claud. 25, 5; 29, 1. Tac. Ann. 12, 7, 5-7.

${ }^{238}$ MCALINDON, D. Senatorial Opposition to Claudius and Nero. AJPh, v. 77, n. 2 (1956), p. 117-118.
} 
imperial. O segundo se destaca pelo apoio a Agripina e ocupava o cargo de rationibus, um secretário de finanças que era responsável pelas contas e pela gestão do fisco (o tesouro imperial) ${ }^{239}$.

Porém esses e outros atos, e de fato quase toda a condução de seu principado era ditada não muito por seu próprio julgamento, mas por suas esposas e libertos, tendo em vista que ele quase sempre agia em concordância com os desejos e interesses destes. (Suet. Claud. 25, 5)

Suetônio destaca a influência exercida pelos libertos e esposas sobre Cláudio de forma muito clara em seu texto, como vemos no trecho anterior. Tácito incluiu esse controle com a grande participação desses elementos em alguns assuntos do governo e da vida do imperador, especialmente na descrição do quarto casamento de Cláudio, um matrimônio que finalmente vai ligá-lo a Augusto.

Com a morte de Messalina, segundo Tácito, os libertos defendiam as candidatas à quarta esposa do imperador Cláudio, que não suportaria a vida celibatária. O liberto Calisto - que teve importante papel na época da morte de Calígula - defendia Lólia Paulina ${ }^{240}$ por não ter filhos e que dessa forma assumiria um papel materno para os filhos do imperador. Narciso defendia Élia Petina que já havia sido casada com o imperador e tinha uma filha dele, assim os filhos de Messalina seriam irmãos consanguíneos de sua filha Antônia. Calisto era contra devido ao longo divórcio e que provavelmente ela se tornaria arrogante se fosse chamada novamente ${ }^{241}$. Palas defendia uma candidata mais nobre que as outras e que traria o benefício do vínculo com Augusto:

Palas, em sua defesa de Agripina, insistiu no ponto de que ela trazia consigo o neto de Germânico, digno, sem dúvida, da posição imperial. Era de uma linhagem nobre e, posteriormente, ligaria as famílias Júlia e Cláudia; e era uma mulher comprovadamente fértil, ainda no vigor da juventude, não poderia transferir a glória dos Césares para outra família. (Tac. Ann. 12, 2, 3.)

\footnotetext{
${ }^{239}$ BARRETT, Anthony A. (1996). op. cit., p.75-77. GIARDINA, Andrea (Org.). O Homem Romano. Lisboa: Presença, 1992, p.153-160. WEAVER, P. R. C.. Movilidad social en el alto imperio romano: la evidencia de los libertos imperiales y los esclavos. In: FINLEY, M. Estudios sobre historia antigua. Madrid, Akal Editor, 1981, p. 144-145; 149-156.

${ }^{240}$ Ela foi esposa de Calígula.

241 Tac. Ann. 12, 1-2.
} 
A origem nobre e a fecundidade comprovada de Agripina Menor venceram as concorrentes, mas Tácito deixa claro que ela se valeu de seu parentesco para seduzir o tio ${ }^{242}$; acusação semelhante à feita a sua irmã Livila, que fora punida com exílio e morte. Suetônio destaca pontos semelhantes, porém sem incluir os libertos nesta escolha, Cláudio decidiu por si próprio se casar novamente e foi seduzido por sua sobrinha.

No entanto, ele não poderia privar-se de mais uma vez planejar um novo casamento, mesmo com Petina, a quem ele tinha anteriormente descartado e com Lólia Paulina, que tinha sido a esposa de Caio César. Mas sua afeição foi ludibriada pelos encantos de Agripina, filha de seu irmão Germânico, auxiliada pelo direito de trocar beijos e as oportunidades de carinhos oferecidas por sua relação [familiar]; e no encontro seguinte do Senado ele subornou alguns membros a proporem que ele deveria ser compelido a se casar com Agripina, sendo esta união de interesse máximo para o Estado e para o restante [dos cidadãos] estava permitido contrair matrimônio similar, que até aquele tempo era considerado incestuoso. E ele se casou com ela passado apenas um dia; porém nenhum outro seguiu seu exemplo, salvo um liberto e um centurião, cujo casamento ele compareceu em pessoa junto de Agripina. (Suet. Claud. 26, 3)

Agripina Menor realmente poderia ter se valido de seu parentesco para se aproximar do tio e garantir ser a escolhida dele; ela possuía, ainda, uma ascendência nobre que estabeleceria uma ligação entre Cláudio e Augusto. Entretanto, temos que considerar a relação dentro o palácio; segundo Suetônio, o próprio Cláudio dizia que ela havia nascido e sido criada em seus braços ${ }^{243}$. Como dito anteriormente ${ }^{244}$, Lívia cuidou de algumas das crianças de Germânico e Agripina Maior; porém, durante um período, algumas das crianças permaneceram com Cláudio, ou Druso - filho de Tibério -, e foram levadas para recepcionar a mãe quando ela trouxe as cinzas do pai. Mesmo que estivessem com Lívia ou Antônia Menor, que era a avó delas, as crianças conviveram com o tio, que deveria visitar suas parentes com freqüência - um comportamento natural na relação entre mães e filhos homens ${ }^{245}$. Estavam reunidas, também, em festividades e outras comemorações, como durante a escolha do nome do

\footnotetext{
${ }^{242}$ Tac. Ann. 12, 3.

${ }^{243}$ Suet. Claud. 29, 2

${ }^{244}$ Anteriormente tratado nesse trabalho nas páginas 46-47.

${ }^{245}$ DIXON, Suzanne. The Roman Mother. London: Routledge, 1990, p 169-170.
} 
filho de Agripina - Lúcio Domício Enobarbo.; Cláudio estava lá e foi destacado na zombaria de Calígula ${ }^{246}$.

A série de casamentos endogâmicos na domus Augusta gerava essas situações; em um momento estavam sendo criadas juntas algumas crianças e em outro elas estavam se casando dentro daquele grupo. Com uma morte ou um divórcio, um novo matrimônio poderia ser realizado dentro do mesmo grupo 247. Dessa forma, seria possível que Livila e Agripina tivessem uma relação carinhosa com o tio; entretanto, se considerarmos que elas haviam sido acusadas de possuírem um amante em comum - que seria ainda um cunhado -, junto das insinuações de incesto com o irmão, poderíamos considerar plausíveis os trechos de Tácito e Suetônio que indicam essa aproximação antes do matrimônio. As acusações de incesto são uma das formas de atacar mulheres, assim como as acusações de adultério ${ }^{248}$; essas acusações foram utilizadas durante todo o período para afastar possíveis concorrentes ao poder.

Seguindo a linha de raciocínio de que Cláudio era controlado por sua esposa e ainda fazendo uso de uma masculinizada Agripina Menor, Tácito informa que o governo agora estava sobre seu domínio.

\begin{abstract}
A partir desse momento houve uma mudança na vida pública e todas as coisas submeteram-se aos decretos de uma mulher mas não uma mulher que, como Messalina, trata de forma libertina o império Romano, como um brinquedo. Era uma linha tênue, quase um despotismo masculino: em público, havia a austeridade e não pouco frequente a arrogância; em casa, nenhum traço de lascívia, a menos que contribuísse para o poder. Uma paixão ilimitada por ouro tinha como desculpa a criação de um suporte ao governo. (Tac. Ann. 12, 7, 5-7.)
\end{abstract}

Mulheres que se aproximam das esferas masculinas são malvistas em Roma; Agripina Maior, na época da destruição da ponte, e Plancina, participando de exercícios militares ${ }^{249}$, foram criticadas por suas atitudes

\footnotetext{
${ }^{246}$ Anteriormente tratado nesse trabalho na página 83.

${ }^{247}$ BRADLEY, K.R. Remarriage and Structure of the Upper-Class. In: RAWSON, Beryl (ed.). Marriage, divorce, and children in Ancient Rome. Canberra, Oxford: Humanities research Centre, Clarendon Press, 1991, p. 83. CORBIER, Mireille. Poder e parentesco. A família JúlioCláudia. Tradução de Consuelo Fontes Santiago. Classica, São Paulo, 5/6, 1992/1993, p. 192193.

${ }^{248}$ DIXON, Suzanne ( 2007). op. cit., p. 33-35. GINSBURG , Judith. op. cit., p. 119-121.

${ }^{249}$ Anteriormente tratado nesse trabalho na página 70.
} 
ligadas às atividades militares ${ }^{250}$. Agripina Menor também é descrita como sendo diferente de Messalina, que se comportava de forma lasciva; Agripina é uma mulher sempre em busca do poder, de acordo com Tácito.

Uma questão ainda relacionada ao casamento é a perseguição de Lólia Paulina; Tácito atribui isso ao ódio de Agripina Menor por ela ter sido uma de suas concorrentes na questão do casamento com Cláudio ${ }^{251}$. Mais do que apenas relações de ódio entre as mulheres, devemos considerar que Lólia esteve anteriormente vinculada ao palácio em seu casamento com Calígula; e se seu nome havia sido considerado nesse novo matrimônio, seja pelos libertos ou pelo próprio Cláudio, ela seria uma concorrente a posição de Agripina. $\mathrm{Na}$ mesma descrição, Tácito atribui novamente apenas ao ódio e personalidade violenta de Agripina a condenação de Calpúrnia, pois Cláudio admirava a beleza desta ${ }^{252}$. Neste ponto devemos considerar que Cláudio estava em seu quarto casamento e que havia abandonado uma de suas esposas por ofensas triviais; mesmo casada com o imperador, Agripina poderia não ter se sentido segura em sua posição e instigado a condenação destas mulheres, que eram consideradas possíveis concorrentes.

Tácito informa que antes mesmo de casada com Cláudio, Agripina planejava o casamento de seu filho Domício com a filha de seu futuro marido. Otávia estava noiva de Lúcio Júnio Silano que foi perseguido e também acusado de cometer incesto com sua irmã Júlia Calvina ${ }^{253}$. O autor coloca essa situação como mais um crime de Agripina contando com a ajuda de Vitélio, seu aliado no Senado ${ }^{254}$; entretanto Lúcio e Otávia não eram casados ainda e poderiam apenas ter esse compromisso desfeito. A família Júnia Silana teve frequentes conflitos com os imperadores, sendo algumas mulheres $\mathrm{e}$ alguns dos homens deste grupo exilados, perseguidos e mortos por Tibério, Calígula, Cláudio e também Nero; acredita-se que Cláudio teria realizado esse

\footnotetext{
${ }^{250}$ GINSBURG , Judith. op. cit., p. 112-114. HEMELRIJK, Emily Ann. Matrona docta: educated women in the Roman élite from Cornelia to Julia Domna. London: Routledge, p. 89-92. RUTLAND, Linda W. Women as Makers of Kings in Tacitus' Annals. CW, v. 72, n. 1 Sep., 1978, p. 23. SYME, Ronald. Princesses and Others in Tacitus. G\&R, Second Series, v. 28, n. 1 (Apr., 1981), p. 47.

${ }^{251}$ Tac. Ann. 12, 22, 1.

252 De acordo com Tácito, Calpúrnia era de uma família nobre, parte da rede de conhecidos do imperador, que foi elogiada em uma conversa casual. Tac. Ann. 12, 22, 4.

${ }_{253}^{25}$ Tac. Ann. 12, 3-4.

${ }^{254}$ Ele participou dos esforços no Senado para tornar o casamento entre sobrinha e tio não mais incestuoso.
} 
noivado como uma tentativa de ganhar apoio das famílias nobres romanas no começo de seu principado. Ainda, devemos considerar que esta família possuía vínculos com Augusto, pois Lúcio era filho de Emília Lépida que era filha de Júlia II, a neta banida de Augusto; dessa forma eles também poderiam ser considerados concorrentes ao poder, concorrentes do filho de Agripina. Júnia foi banida; Silano se suicidou no dia do casamento; e o irmão mais velho deles, Marco, foi envenenado ${ }^{255}$.

(...) uma lisonja mais refinada foi concedida a Domício; e a lei se encarregou de providenciar sua adoção na família Cláudia com o nome de Nero. A própria Agripina recebeu o título de Augusta. (Tac. Ann. 12, 26, 1-2.)

Agripina recebeu uma honra que Lívia só recebeu após a morte de seu marido, uma honra que Cláudio havia negado para sua esposa anterior, Messalina; isto demonstra que sua ascendência nobre realmente foi um fator fundamental nessa união. Nero, agora filho adotivo do imperador, casou-se com Otávia, que foi adotada por outra família para não constituir incesto, tendo em vista que os dois se tornaram irmãos com essa adoção. Este trecho de Tácito continua com o isolamento do filho biológico de Cláudio, Britânico; o autor informa que ele foi privado dos serviços dos escravos depois desta adoção; em outro ponto Tácito relata que ao chamar Nero por Domício, Agripina se queixou ao marido e seus aios foram exilados e condenados à morte, tendo seus novos preceptores indicados pela madrasta ${ }^{256}$. Com relação à educação de seu filho biológico, sabemos que ela foi muito cuidadosa na escolha de seus tutores trazendo de volta Sêneca, que havia sido exilado durante o período de Calígula.

Agripina, por outro lado, para não se notabilizar apenas pelos crimes, obteve a remissão do banimento de Aneu Sêneca, juntamente com uma pretoria: sua fama literária, ela supôs, tornaria o ato agradável ao povo; enquanto ela estava ansiosa para ganhar assim um distinto tutor para Domício em sua passagem da infância para a adolescência; e para lucrar com o seu conselho em seus projetos de dominação. A crença era de que Sêneca foi vinculado à Agripina pela memória de sua bondade e hostil a Cláudio pelo ressentimento da ofensa recebida. (Tac. Ann. 12, 8, 4.)

\footnotetext{
${ }^{255}$ MCALINDON, D. (1956). op. cit., p. 119-122. BARRETT, Anthony A. (1996). op. cit., p. 99.

${ }^{256}$ Tac. Ann. 12, 26, 4; 41, 8.
} 
De acordo com o excerto anterior Agripina é uma mulher que comete diversos crimes e mesmo suas ações positivas são pautadas pela busca do poder. A esmerada educação de Nero pode ser compreendida como uma preparação para assumir o poder, mas deve ser pensada como sendo comum aos jovens da domus Augusta ${ }^{257}$; como vimos anteriormente Augusto educou as crianças de sua família junto de outros nobres e relevantes tutores foram constantes nesse processo. Otávia - irmã de Augusto - queixava-se da perda de seu filho Marcelo, jovem promissor, bem educado e considerado um herdeiro natural de seu tio. Este não era o único caso de informações sobre educação; nas cartas que Augusto trocou com Lívia sobre Cláudio ele comenta as graciosas declamações dele ${ }^{258}$. A preparação dos meninos era algo relevante; e talvez, se considerarmos essa busca pelo poder de Agripina, a troca dos professores de Britânico pode ser considerada uma forma de evitar o seu desenvolvimento, controlando os temas de seus estudos.

A cidade dos úbios, em que Agripina nasceu, tornou-se uma colônia de veteranos pouco depois de seu matrimônio com Cláudio, recebendo seu nome; Tácito atribui esta criação da colônia a mais uma mostra de poder dela ${ }^{259}$. Certamente isto foi uma grande honra, assim como receber o nome Augusta e ter sua imagem difundida em diversas representações pelo império. Outras mulheres da família foram representadas e pensando na relação de Agripina e Cláudio, devemos ter em mente o vínculo com Augusto obtido com esse matrimônio; entretanto, uma peculiaridade em algumas estátuas de Agripina deve ser destacada. Foram reutilizadas algumas estátuas de Messalina para a representação de Agripina Menor; poderíamos pensar em um reaproveitamento do material, mas em uma das estátuas de Messalina, que estava em uma basílica na cidade de Veleia, a cabeça de Agripina é desproporcional ao corpo. Outras imagens de Messalina foram transformadas em imagens de Agripina e este é um processo que ocorreu também com outras figuras romanas, todavia

${ }^{257}$ DIXON, Suzanne ( 1990). op. cit., p. 170-172. HEMELRIJK, Emily Ann. op. cit., p. 69; $103-$ 104. MORFORD, Mark P. O. The Training of Three Roman Emperors. Phoenix, v. 22, n. 1 (Spring, 1968), p. 57-65.

${ }_{258}$ Conforme exposto nas páginas 46 deste trabalho.

259 Tac. Ann. 12, 27, 1. 
pode ser considerado uma expressão visual de uma rivalidade política ${ }^{260}$. Poderíamos pensar em erro no cálculo do tamanho da nova cabeça, porém, podemos pensar que isto é uma forma de mostrar que Agripina Menor havia assumido a posição de esposa do imperador e que os aliados da antiga esposa não teriam mais influência. Isto vai ao encontro das informações observadas no trecho a seguir:

\begin{abstract}
Até então, porém, Agripina não tinha coragem de fazer seu principal ataque, a menos que ela pudesse trocar os comandantes das cortes pretorianas Lúsio Geta e Rúfio Crispino, que ela acreditava que permaneciam fiéis à memória de Messalina e comprometidos a causa do filho dela. Assim, por meio das afirmações dela ao seu marido de que os soldados estavam sendo divididos por intrigas e rivalidades dos dois e de que a disciplina seria mais rigorosa se eles fossem colocados sob um único comandante; o comando foi transferido para Afrânio Burro, que possuía as melhores características como um soldado, porém sabia a quem devia sua nomeação. A exaltação de sua própria dignidade também ocupava Agripina: ela começou a entrar no Capitólio em uma carruagem, uma honra concedida desde os tempos antigos aos sacerdotes e aos objetos sagrados; e que realçava a veneração que [os romanos] sentiam por uma mulher que até hoje permanece sem paralelo como a filha de um Imperator, a irmã, a esposa e mãe de príncipe. (Tac. Ann. 12, 42, 1-3.)
\end{abstract}

Agripina Menor mostra que sua influência é muito grande nesse ponto; acusar possíveis concorrentes ao poder de certa forma ajudava, também, o principado de Cláudio; porém, retirar apoiadores de Messalina, ou os que ela acreditava ser, significa uma clara defesa de sua posição de esposa e em última instância da posição de seu filho. Sexto Afrânio Burro tinha sido o procurador de Lívia e será um dos principais aliados de Agripina durante o período de Cláudio. Junto dessa mostra de influência em uma questão militar, Tácito inclui ainda a honra de usar o carpentum, uma carruagem concedida para pouquíssimas pessoas. O autor destaca que essa honra reforçava ainda mais a veneração que os romanos sentiam por uma mulher; e a liga a sua posição na família, descendente de Augusto pela sua ascendência feminina, filha de Germânico, irmã de Calígula, esposa de Cláudio e seu filho Nero se tornaria o último dos imperadores da dinastia Júlio-Claudiana. Agripina era

\footnotetext{
${ }^{260}$ VARNER, Eric R. Portraits, Plots, and Politics: Damnatio memoriae and the Images of Imperial Women. MAAR, v. 46, 2001, p. 65-68.
} 
uma mulher inteligente que sabia se posicionar em meio às intrigas do palácio, ela soube se valer de sua origem nobre em seu casamento e soube se manter cercada de aliados; entretanto Cláudio se valeu destas honras - e do título de Augusta também - de forma a realçar seu vínculo com Augusto e Germânico, principalmente, destacando sua esposa.

Atribuí-se à Agripina a nomeação como procurador da Judéia de Félix, irmão do liberto Palas ${ }^{261}$. Tácito diz que por meio de ameaças, Agripina obteve a defesa do senador Vitélio da acusação de lesa-majestade feita pelo, também, senador Júnio Lupo; graças a esta intervenção Cláudio condenou o acusador ao exílio. Agripina não só recebeu honras, como estava presente ao lado do marido em alguns eventos, como por exemplo, o combate naval no lago Fucino em que Cláudio aparece com vestes militares e Agripina usando uma clâmide tecida de ouro. Após o término do combate, o escoamento da água não ocorreu como previsto e utilizaram um combate de gladiadores e um banquete pra desviar a atenção dos presentes deste problema. Agripina teria aproveitado a ocasião e culpado o liberto Narciso pelo ocorrido ${ }^{262}$; este liberto teria defendido outra candidata na questão do casamento do príncipe.

Outra questão mostra o desacordo entre Narciso e Agripina: a condenação de Domícia Lépida. Ela era cunhada e prima de Agripina, irmã de seu primeiro marido e filha de Antônia Maior (Tácito comete um engano dizendo que esta era filha de Antônia Menor, a mãe de Cláudio); o autor diz que ela se julgava de igual beleza e nobreza e, ainda, utilizava-se de presentes e carinhos para conquistar a afeição de Nero, enquanto Agripina queria dar ao filho o império. Domícia foi acusada de sortilégios contra a prima e ainda de perturbação da paz, pois seus escravos em bando infestavam parte da Itália (a região da Calábria); ela foi condenada à morte mesmo com a oposição de Narciso ${ }^{263}$. Novamente, devemos pensar que Domícia era parte da domus Augusta e que exercia certa influência em Nero, ela era ainda a mãe de Messalina - antiga esposa do imperador; desta forma sua condenação afasta as chances de atrapalhar seu objetivo, que era o de colocar o filho no poder. Tácito, mesmo incluindo Agripina Menor como uma mulher que desejava o

\footnotetext{
${ }^{261}$ Tac. Ann. 12, 54.1. Suet. Claud. 28, 1. BARRETT, Anthony A. (1996). op. cit., p. 128.

262 Tac. Ann. 12, 56-57.

${ }^{263}$ Tac. Ann. 12, 64-65.
} 
poder, nesta questão informa claramente que ela queria que o filho assumisse o poder.

O último evento narrado por Tácito no livro XII é a morte de Cláudio, envenenado por sua esposa após o afastamento de Narciso (que estava doente). Agripina faz uma cautelosa escolha do veneno que seria utilizado em seus alimentos no jantar; entretanto, a embriaguês de seu marido associada a um mal de estômago impediram a ação do veneno. Ela teria então, contando com a ajuda do médico Xenofonte, feito Cláudio beber o veneno durante o tratamento de sua enfermidade anterior. $O$ autor descreve que ela impediu que os filhos biológicos - Britânico, Otávia e Antônia - se aproximassem do pai e ainda buscava consolá-los; ela teria cercado a casa com guardas e mandado notícias sobre a melhora do imperador, sendo que este já estava morto. Ela teria feito tudo isso para garantir o tempo necessário para preparar a ascensão de seu filho ao poder. Nero foi, acompanhado por Burro, encontrar-se com soldados e foi aclamado imperador por eles, seguidos pelo Senado e pelas províncias. Ainda, os soldados teriam notado a ausência de Britânico quando Nero e Burro foram encontrá-los; entretanto, não houve protestos ${ }^{264}$. Destacase neste ponto que Agripina imitou as atitudes de Lívia, o cercamento do palácio e o anúncio otimista sobre a saúde do imperador, atitudes que serviriam para não causarem excessos devido à comoção popular.

A sucessão de Nero recebeu a ajuda de Agripina, mas não apenas neste momento final. Nero havia recebido a toga viril antes da idade que normalmente receberia; a ele foram concedidas certas honras como a permissão de ocupar o consulado com vinte anos e que lhe fosse designado o poder proconsular fora da cidade de Roma, assim como o título de príncipe da juventude. Víveres foram distribuídos para a plebe e donativos aos soldados em seu nome; e em jogos circenses, Britânico apareceu com a toga juvenil e Nero com as insígnias triunfais, de forma a deixar clara a diferença entre os irmãos ${ }^{265}$. Mesmo que Agripina tivesse influenciado o recebimento dessas honras e o avanço de sua carreira, Nero recebeu alguns dos poderes que outrora Augusto havia dado aos seus sucessores e Britânico não recebeu as mesmas honras.

\footnotetext{
${ }^{264}$ Tac. Ann. 12, 66-69, 1-5.

265 Tac. Ann. 12, 41, 2-5.
} 
Suetônio descreve a morte de Cláudio de forma muito semelhante a Tácito; entretanto ele destaca a aproximação do imperador com seu filho biológico, assim como o arrependimento pelo casamento com Agripina e a adoção de Nero, sendo estas as causas de seu assassinato pela esposa ${ }^{266}$. Como foi dito, Britânico não recebeu honras ou qualquer outro destaque foi mencionado nas fontes ${ }^{267}$; mesmo que Cláudio quisesse conceder a toga viril a seu filho ou honrá-lo de outra forma, não é possível saber. Seu testamento não foi lido ${ }^{268}$, mas por meio dele não se poderia transmitir cargos. Agripina Menor agora era mãe do imperador e no começo do principado do filho recebeu grandes honras.

\subsection{Agripina e Nero: da influência materna ao fim da dinastia}

Suetônio nos informa que logo após os funerais de Cláudio, Nero colocou sua mãe a frente de todos os negócios públicos e privados ${ }^{269}$. Ele não fornece maiores detalhes sobre esta afirmação; como ela não poderia exercer cargo algum e se realmente estivesse cuidando dos assuntos públicos a população, Senado e outros autores teriam comentado tamanha estranheza. Entretanto, podemos compreender que ela possuía grande influência nesse período, provavelmente dava conselhos sobre as questões públicas e privadas e estes eram seguidos. Tácito apenas informa as grandes honras recebidas por ela neste momento.

Ainda, em público, todos os cumprimentos eram dirigidos à Agripina; e quando o tribuno - seguindo a rotina militar - pedia a senha, seu filho respondia: "A melhor das mães". O Senado, também, concedeu a ela um par de lictores e ainda o posto de sacerdotisa do culto a Cláudio, que foram votados na mesma sessão do funeral público seguido da apoteose. (Tac. Ann. 13, 2, 5-6.)

\footnotetext{
${ }^{266}$ Suet. Claud. 43-45.

${ }^{267}$ AVELINE, John. The Death of Claudius. Historia, v. 53, n. 4 (2004), p. 457-459.

${ }^{268}$ Tac. Ann. 12, 69, 7.

${ }^{269}$ Suet. Nero. 9, 1.
} 
Agripina recebeu as mesmas honras que Lívia havia recebido após a morte de Augusto; mais ainda, pois os lictores de Lívia eram permitidos somente no exercício da função de sacerdotisa do culto de Augusto. Tácito informa que nos funerais de Cláudio, Agripina teria se empenhado em imitar sua bisavó Lívia ${ }^{270}$. Destaca-se que as cenas das mortes de Augusto e Cláudio são semelhantes; ambas as esposas cercaram a casa e o anúncio da morte do imperador foi dado junto do anúncio da sucessão. Lívia, como já falamos, era uma referência de comportamento para as mulheres romanas e Agripina conviveu com a bisavó. Agripina Menor valorizou sua ascendência especialmente destacando sua mãe, seu pai e seu vínculo com Augusto, mas não temos informações de referências à Lívia.

Tácito inicia a descrição do principado de Nero relatando as primeiras mortes desse período. Como citado anteriormente nesse capítulo, o irmão mais velho de Silano, Marco, havia sido envenenado e isso ocorre no começo do principado de Nero. Além desta morte, um dos inimigos políticos de Agripina, o liberto Narciso, é compelido ao suicídio e Tácito informa que isso foi realizado contra a vontade de Nero ${ }^{271}$. Narciso era extremamente fiel a Cláudio e a morte do imperador só ocorreu após o afastamento deste; possivelmente ele era considerado um risco ao principado de Nero, podendo apoiar Britânico em um golpe.

O discurso de Nero no Senado é muito importante, pois nele o novo imperador garantiu que os assuntos do palácio não mais se misturariam aos assuntos públicos; que ao Senado seriam asseguradas suas antigas atribuições; e que o imperador não deveria julgar todas as causas para que a justiça não ficasse ao arbítrio de poucos ${ }^{272}$. Tácito afirma que a promessa se cumpriu. O Senado aprovou decretos mesmo com a oposição de Agripina.

A promessa não foi desonrada e muitos regulamentos foram criados pela livre decisão do Senado. Ninguém devia vender seus serviços por qualquer comissão ou recompensa para pleitear alguma causa; questores designado não deveriam ser obrigados a produzir espetáculos de gladiadores. Sobre os espetáculos, Agripina se opôs a isto como uma subversão dos atos de Cláudio; por este motivo foi realizada uma reunião dos

\footnotetext{
${ }^{270}$ Tac. Ann. 12, 69, 6.

271 Tac. Ann. 13, 1.

272 Tac. Ann. 13, 4.
} 
senadores, especialmente convocados no palácio, para que ela pudesse se posicionar em uma recém-adicionada porta aos fundos e que era coberta por uma cortina espessa o suficiente para escondê-la, porém não a impedia de ouvir. De fato, quando emissários Armênios foram defender a causa de seu povo perante Nero, ela estava se preparando para subir até a tribuna do imperador para acompanhá-lo; todos ficaram horrorizados, menos Sêneca, que advertiu o soberano que fosse ao encontro de sua mãe: uma mostra da piedade filial, que evitou um escândalo. (Tac. Ann. 13, 5.)

Agripina escutava as reuniões senatoriais realizadas no palácio, e esta parte do discurso de Nero não se cumpriu. Barrett considera esta possibilidade uma grande honra ${ }^{273}$, provavelmente mais um sinal de sua boa relação com o filho e sua influência no começo do principado dele. Com relação à interferência direta descrita no trecho de Tácito, Cláudio poderia fazer uso da presença de Agripina nos eventos públicos de forma a destacar seu vínculo com Augusto, mas Nero não precisava deste tipo de destaque, porque também era descendente de Augusto; desta forma, a presença dela durante a reunião com os emissários Armênios foi considerada negativa, sendo necessária uma ação rápida para que tal fato não se tornasse um escândalo. Durante 0 principado de Nero existiam comentários a respeito de sua juventude e especialmente sobre o fato de ser influenciado por uma mulher ${ }^{274}$. Agripina só volta a ser citada por Tácito durante o envolvimento de Nero com a liberta Atéia.

Nero havia se envolvido com uma liberta e era acobertado por amigos, especialmente por Sêneca; Agripina protestou contra esse relacionamento, porém tentou por meio de carinhos e gentilezas cativar novamente o filho. Nero Ihe enviou presentes que causaram descontentamento ao saber a resposta da mãe, que disse que ele dividia os bens que obteve graças a ela. Após este desentendimento Nero dispensou Palas de sua função; este era o maior aliado de Agripina desde os tempos de Cláudio e ela respondeu a mais esta perda de influência voltando-se para Britânico ${ }^{275}$.

Agripina alegava que Britânico encontrava-se em idade adequada ${ }^{276}$ para ocupar seu lugar no império, um lugar que vinha sendo ocupado por um filho adotivo - Nero - que estava injuriando a própria mãe. Dizia ainda que o

\footnotetext{
${ }^{273}$ BARRETT, Anthony A. (1996). op. cit., p. 150.

${ }^{274}$ Tac. Ann. 13, 6, 2.

275 Tac. Ann. 13, 13-14.

${ }^{276} \mathrm{O}$ jovem estava próximo da idade de recebimento da toga viril.
} 
levaria aos acampamentos militares ${ }^{277}$, da mesma forma como o próprio Nero e Cláudio haviam sido levados e declarados imperadores perante as tropas.

Nero cedeu à pressão de sua mãe e a ele é atribuído o planejamento da morte de Britânico; ele foi envenenado durante um jantar, no qual Tácito destaca a presença de Agripina e Otávia - esposa de Nero - e que estas transpareceram desconhecer o plano, entretanto elas notaram que Britânico estava sendo assassinado e não sofrendo um de seus costumeiros ataques epiléticos ${ }^{278}$.

Suetônio informa sobre a questão da liberta Atéia, que ela quase se casou com Nero ${ }^{279}$; Barrett acredita que Agripina não se irritaria apenas por um envolvimento casual com a liberta, pois era comum aos homens nobres esse tipo de relação extraconjugal. Entretanto para o autor, Agripina acreditava que seu filho faria uso de seu poder imperial ${ }^{280}$ para realizar esse matrimônio ${ }^{281}$. Nero não realizou oficialmente esta união e não podemos garantir que Agripina tenha se desentendido com o filho por acreditar que ele iria contrair um casamento com uma liberta.

Sua mãe o ofendeu pela vigilância muito rigorosa e crítica às suas palavras e atos, mas no começo ele limitou o seu ressentimento a esforços frequentes para colocar sobre ela uma carga de impopularidade, fingindo que iria abdicar do trono e mudar-se para Rodes. (Suet. Nero. 34, 1)

De acordo com esse trecho de Suetônio podemos notar que Agripina estava criticando seus atos e suas falas de forma rigorosa; Tácito inclui brevemente que ela era severa ao reprimir o filho ${ }^{282}$. Existiam comentários sobre a juventude e o controle dele por sua mãe; entretanto, esta mocidade era o que permitia Agripina ter um controle maior sobre seu filho ${ }^{283}$. Cláudio podia

\footnotetext{
${ }^{277}$ Tac. Ann. 13, 14, 4-6.

${ }^{278}$ Tac. Ann. 13, 15; 16, 5-6.

${ }^{279}$ Suet. Nero. 28, 1.

${ }^{280}$ Como dito anteriormente neste trabalho, Augusto no século 18 a.C. por meio da lei lex lulia de Maritandis Ordinibus proibiu o casamento de membros da ordem senatorial com libertos. Desta forma, para a realização desse casamento Nero deveria utilizar estratégia semelhante à utilizada por Cláudio na obtenção da permissão para se casar com sua sobrinha Agripina Menor. Suetônio informa (Nero. 28, 1.) que ele subornou alguns personagens consulares para que garantissem a origem nobre de Atéia.

${ }^{281}$ BARRETT, Anthony A. (1996). op. cit., p. 168.

${ }^{282}$ Tac. Ann. 13, 13, 2-3.

${ }^{283}$ CAZENAVE, Michel e AUGUET, Roland. Os imperadores loucos: Ensaio de mito-análise histórica. Portugal: Inquérito, [s.d.], p.152.
} 
se valer de ascendência de sua esposa e considerar seus comentários e atitudes úteis para segurança de sua posição; porém, Nero também considerava os conselhos de Burro e Sêneca e quando a intervenção de sua mãe tornou-se pública, como no caso com os emissários Armênios, somados ainda aos boatos e às ideias do próprio príncipe, os desentendimentos podem ter chegado a um ponto irreversível; o ponto culminante pode ter sido a questão do relacionamento com a liberta Atéia, mas não se pode tratar como apenas uma rivalidade entre mulheres que queriam influenciar Nero.

Entretanto, a ira de Agripina não se abrandava por nenhuma
generosidade. Amparava e favorecia Otávia; frequentemente
tinha colóquios secretos com amigos; recolheu dinheiro de
todas as fontes com uma voracidade maior que a comum,
aparentemente para criar um fundo para emergências; tribunos
e centuriões eram recebidos com afabilidade; e aos nomes e
virtudes da nobreza - que ainda restavam - ela mostrou um
respeito que indicava que ela estava buscando um líder e uma
facção. Nero sabia e deu ordens para retirar a guarda militar,
que ela recebeu como esposa e manteve como mãe do
soberano, junto com a dos Germanos posteriormente
designados a ela como seguranças pelo mesmo motivo. Para
que o palácio não fosse frequentado por uma multidão de
visitantes, transferiu sua mãe para a casa que tinha pertencido
a Antônia; e em suas visitas para saudá-la estava cercado de
centuriões e partia após um beijo ligeiro. (Tac. Ann. 13, 18, 4-
6.)

Agripina Menor buscou reforçar suas amizades com as famílias mais nobres de Roma - até mesmo a família Silana - e também fazer reservas de dinheiro. A partir das informações deste excerto podemos perceber que ela possuía muita relevância, tendo em vista um dos motivos alegados para retirála da casa era o grande número de pessoas que a visitavam. Todavia podemos compreender que após retirar seu principal aliado, Nero queria afastá-la do palácio. Sua presença lá, devido à possibilidade de escutar as reuniões senatoriais, a manteria próxima ao governo. Afastá-la fisicamente impediria, em parte, as críticas constantes e as possibilidades de articulações, ou ao menos retardaria estas ações. Outro ponto que pode ser notado é que ela foi instalada na casa que havia sido da mãe de Germânico, sua avó Antônia Menor. Supõese que ela recebeu todos os bens que pertenceram à avó aumentando ainda mais sua fortuna, pois na época de sua morte surgiram dúvidas sobre em quais 
das casas que ela possuía teria falecido; algumas dessas opções eram residências de Antônia Menor ${ }^{284}$.

Nada na lista de coisas mortais é tão instável e tão fugaz quanto à fama ligada a um poder não baseado na sua própria força. Imediatamente a porta de Agripina foi abandonada: não havia condolências; não havia visitas, com exceção de algumas mulheres, seja por amor ou ódio é incerto. Entre elas estava Júnia Silana, separada por Messalina de seu marido Silano, como já contei antes. Eminente igualmente no sangue, volúpia, beleza, ela era amiga de longa data de Agripina. Em seguida, veio uma briga privada entre as duas: Agripina tinha dissuadido o jovem nobre Sexto Africano de se casar com Silana, descrevendo-a como uma mulher sem moral e idade incerta; não com a intenção de reservar Africano para si própria, mas para manter a viúva rica e sem filhos fora do controle de algum marido. Com a possibilidade de vingança apresentandose, Silana subornou dois de seus clientes - Itúrio e Calvísio para realizar a acusação; estes ataques não eram antigos e repetidos como o boato frequentemente ouvido de que Agripina estava de luto pela morte de Britânico e que comentava os erros de Otávia, mas sobre ela estar encorajando Rubélio Plauto a uma revolução - pelo lado materno ele era um descendente do divino Augusto no mesmo nível que Nero como um parceiro em sua cama e depois no trono, abrindo o caminho mais uma vez para a condução dos negócios. (Tac. Ann. 13, 19, 1-4.)

Estas intrigas e boatos, presentes no trecho de Tácito, não podem ser considerados apenas desentendimentos entre mulheres. Júnia Silana estava vinculando Agripina com um descendente de um imperador. Rubélio Plauto era filho de Júlia ${ }^{285}$, que era filha de Druso II - filho do imperador Tibério - e de Livila - filha de Antônia Menor e Druso, irmã do imperador Cláudio e sobrinha neta de Augusto. A mãe de Plauto, Júlia, foi banida sob Cláudio por meio de intrigas atribuídas à Messalina ${ }^{286}$ : intrigas estas que também não podem ser apenas consideradas como desafeto entre mulheres. Membros ligados a domus Augusta e que eram considerados ameaças ao poder foram eliminados de diversas formas, especialmente os homens; entretanto as mulheres também foram perseguidas e eliminadas; como elas se casavam cedo, geralmente

\footnotetext{
${ }^{284}$ BICKNELL, P. J. Agrippina's Villa at Bauli. CR, New Series, v. 13, n. 3 (Dec., 1963), p. 262. KATZOFF, Ranon. Where Was Agrippina Murdered? Historia, v. 22, n. 1 (1st Qtr., 1973), p. 73-76. MCDANIEL, Walton Brooks. Bauli the Scene of the Murder of Agrippina. CQ, v. 4, n. 2 (Apr., 1910), p. 98-102.

${ }^{285}$ BARRETT, Anthony A. (1996). op. cit., p. 87.

${ }^{286}$ Tac. Ann. 13, 32, 4.
} 
tinham filhos antes de sofrerem banimentos e execuções ${ }^{287}$. Rubélio Plauto representaria uma ameaça ao principado e Nero pensou em decretar sua morte, assim como a de sua mãe; pensou ainda em retirar do comando dos pretorianos Burro que devia o cargo a Agripina; porém, este prometeu cumprir a ordem caso fosse provada a acusação ${ }^{288}$ e Agripina Menor pode se defender destas.

Quando os medos do príncipe cessaram, ao romper do dia uma visita foi feita a Agripina; que era para ela ouvir as acusações e respondê-las ou ser penalizada. A comissão foi presidida por Burro, com a supervisão de Sêneca; um número de libertos estava presente também, ouvindo a conversa. Então, depois de recapitular as acusações e seus autores, Burro adotou uma atitude ameaçadora. Agripina falou com seu orgulho: "Não estou surpresa," disse "aquela Silana que nunca conheceu a maternidade, não possuía conhecimento sobre o coração de uma mãe: as mães não podem trocar seus filhos como uma devassa troca seus amantes. Se Itúrio e Calvísio, após consumirem até a última parte de suas finanças, prestaram à sua idosa senhora um último serviço fazendo essas acusações; e era está a razão pela qual minha própria fama devia ser exposta por um infame parricídio e na consciência de César a suspeita disto? Sobre as [acusações] de Domícia - Eu deveria agradecê-la pela inimizade, se ela estivesse competindo comigo pela benevolência de meu Nero, ao invés de encenar essa comédia com a ajuda de seu companheiro de cama Atímeto e seu mímico Páris. Nos dias em que meus conselhos estavam preparando sua adoção, o seu poder proconsular, sua designação para o consulado e as outras etapas de sua soberania, ela estava embelezando as lagoas de peixe de sua amada Baias. - Ou deixe um homem, que permaneça firme, para condenar-me de manipular os guardas de Roma; de abalar a lealdade das províncias; ou, finalmente, de seduzir um escravo ou liberto para o crime! Poderia eu ter permanecido viva com Britânico no poder? E se Plauto ou outro assumissem o poder e se sentassem para julgar, eu acredito que não haveria escassez de acusadores preparados para indiciar-me, não apenas as declarações ocasionais e precipitadas de uma instável emocionalmente, senão delitos, pelos quais somente um filho poderia absorverme?" Os ouvintes foram levados por suas palavras, mas ela exigiu uma entrevista com o filho dela. Lá, nem falou a favor de sua inocência, como se ela pudesse dissipar as dúvidas, nem sobre o tema de suas acusações, como se ela pudesse vê-las em seus lábios, mas obteve vingança contra seus acusadores e reconhecimento para seus amigos. (Tac. Ann. 13, 21)

${ }^{287}$ CORBIER, Mireille (1992/1993). op. cit., p. 185-186.
${ }^{288}$ Tac. Ann. 13, 20, 4. 
A mulher chamada Domícia citada nesse excerto de Tácito é a irmã do primeiro marido de Agripina, que cuidou de Nero durante seu exílio no período de Calígula. As acusações feitas por ela e Atímeto são as mesmas de Silana 289

O primeiro ponto que devemos notar nesse trecho é a presença de libertos ouvindo a defesa; ainda, segundo o próprio trecho eles se deixaram levar pelas palavras desta mulher. Em sua defesa Agripina acusa Silana de lascívia e relembra que esta não teve filhos - e talvez este tenha sido um dos fatores que a manteve viva. Além da acusação de lascívia contra Domícia, Agripina relembra que esteve preparando a adoção e a carreira de Nero, destacando que ele devia sua posição de imperador a ela. Todavia, o ponto de maior destaque é o claro entendimento de que se seu filho não estivesse no poder e o imperador fosse Britânico ou outro, no caso Plauto, ela estaria morta. Agripina demonstra nesse ponto uma compreensão da dinâmica palaciana, caso ela não estivesse ligada ao poder, sua tão destacada origem nobre seria um risco ao governante. Agripina Menor conhecia bem essa dinâmica e sabia fazer uso dela; todas as acusações de assassinatos de parentes, mesmo que distantes, de Augusto ou qualquer pessoa que estivesse ligada a domus Augusta, seja ela a responsável ou não, serviam para a manutenção e segurança da sucessão.

Em seguida, privou-a de todas as honras e de suas guardas de soldados romanos e germânicos; ele mesmo proibiu-a de viver com ele e a retirou do palácio. Depois disso, ele passou todos os limites em persegui-la, subornando homens para pertubá-la com ações judiciais, enquanto ela permaneceu em Roma e depois que ela retirou-se para o interior para repousar, passando por terra ou por mar cobriam-na com abusos e zombarias. Por fim, aterrorizado por sua violência e ameaças, ele determinou retirar a sua vida; e depois de três vezes tentando envenená-la e descobrindo que ela tinha se feito imune por antídotos, ele mexeu no teto de seu quarto, inventando um dispositivo mecânico para soltar seus painéis, que cairiam sobre ela enquanto ela dormia. Quando isso foi descoberto por meio de algumas pessoas ligadas ao plano, ele desenvolveu um barco desmontável, para destruí-la por naufrágio ou pela queda do arco ${ }^{290}$. Em seguida, fingiu uma reconciliação com ela, convidou-a em uma carta muito cordial para vir para Baias e celebrar a festa de Minerva com ele. Em sua chegada, instruindo seus capitães para destruir o barco em que ela chegou, ao colidir com ele como se por acaso; ele

\footnotetext{
${ }^{289}$ Tac. Ann. 13, 19, 5.

${ }^{290}$ Barcos do período possúiam uma cobertura arqueada.
} 
deteve-a em um banquete e quando ela partiu para Bauli, ofereceu-lhe o barco [que havia] construído no lugar da embarcação que tinha sido danificada, acompanhando-a em alto astral e até beijando seu peito enquanto eles se separaram. Passou o resto da noite sem dormir, em uma ansiedade intensa, aguardando o resultado de seu plano. Ao saber que tudo tinha dado errado e que ela tinha escapado nadando; levado ao desespero, ele secretamente atirou um punhal ao lado do liberto de sua mãe Lúcio Agermo, quando este trouxe, com alegria, a informação que ela estava sã e salva; e então ordenou que o liberto deveria ser apreendido e condenado, sob a acusação de ser contratado para matar o imperador; que sua mãe devia ser morta e simulariam que ela havia escapado das conseqüências de sua comprovada culpa cometendo suicídio. Autoridades confiáveis acrescentaram detalhes ainda mais terríveis: que ele correu para ver o cadáver, tocando seu corpo, criticando umas partes e elogiando algumas outras; e que para acalmar a sede ele bebia de tempo em tempo. Entretanto ele não pode suportar, durante ou mesmo depois, suas crises de consciência, embora os soldados, o Senado e as pessoas tentassem animar-lo com felicitações; por diversas vezes ele garantiu que estava sendo assombrado pelo espírito de sua mãe e por chicotes e tochas ardentes das Fúrias. Ele até tinha ritos realizados pelos magos, no esforço para evocar os seus Manes ${ }^{291}$ e aplacá-las. Além disso, em sua viagem pela Grécia, ele não se arriscou a tomar parte nos mistérios de Elêusis; uma vez que na iniciação os ímpios e perversos são excluídos pela proclamação do arauto. Ao matricídio ele acrescentou o assassinato de sua tia. Quando ele a visitou, na época que ela estava confinada à cama por causa de uma constipação, acariciando a barba macia dele (para ele já estava bem crescida) como faziam os anciões, disse carinhosamente: "Assim que eu receber isto [a barba], vou de bom grado morrer", ele virou-se para os que estavam junto dele e disse como se brincando: "Vou tirá-la imediatamente". Então ele mandou os médicos darem a mulher doente uma grande dose de remédios e tomou suas propriedades antes que ela falecesse, suprimindo o testamento dela, assim nada poderia escapar dele. (Suet. Nero. 34, 2-5)

Suetônio não informa com exatidão o motivo que levou o imperador a decidir pela morte de sua mãe, mas dá detalhes de diversas tentativas de assassinato. Em meio a estas descrições, o autor nos informa que Agripina tomava antídotos para se tornar imune às possíveis tentativas de envenenamento. Um fato curioso, já que ela é acusada de ter envenenado o segundo e o terceiro marido. Deixando de lado isso, novamente percebemos uma mulher consciente dos riscos que corria depois do desentendimento com o filho; ela sabia como as coisas ocorriam em meio aos conflitos envolvendo os

${ }^{291}$ Espíritos ou entidades imateriais, espíritos benévolos. 
membros da família imperial. Por fim, Nero é responsabilizado, também, pela morte de sua tia Domícia.

Tácito descreve uma cena mais detalhada da morte de Agripina. Nero se envolve com uma nova mulher - Popéia Sabina - e esta questiona o domínio que a mãe ainda tinha sobre ele e que não poderiam se casar enquanto Agripina fosse viva; o autor informa, que todos não poderiam se opor porque desejavam que o poder de Agripina acabasse ${ }^{292}$. A ausência de Agripina não influenciou na questão do casamento, já que Nero só se casou com ela três anos após a morte da mãe; desta forma, a justificativa dada por Tácito apenas coloca Nero sob a influência de mais uma mulher ${ }^{293}$.

O historiador descreve, então, a possibilidade de ter ocorrido incesto entre mãe e filho, tendo em vista que Agripina já havia cometido tal ato com seu casamento com o tio. Ela teria se aproveitado de momentos que o filho encontrava-se ébrio para tentar seduzi-lo. Percebendo isso, Sêneca trouxe novamente à cena a liberta Atéia que tratou de informar ao imperador que os soldados não tolerariam esse tipo de comportamento ${ }^{294}$, mas não apenas os soldados como todos os romanos. Sobre a questão do incesto, temos as acusações de incesto com Calígula em Suetônio, o casamento com o tio e um comportamento semelhante ao descobrir o envolvimento do filho com a liberta. Ela tentava cativá-lo de forma carinhosa e nesse ponto as acusações de incesto são mais claras. Acusações deste crime são utilizadas para eliminação de inimigos, como foram feitas no caso de Júnio Silano e sua irmã. Mesmo com a autorização para a realização do casamento entre tio e sobrinha, não houve muitos exemplos de parentes que seguiram o exemplo do imperador.

Tácito descreve de forma semelhante todas as tentativas de envenenamento da mãe, frustradas pelo seu hábito de tomar antídotos, e o naufrágio. Na cena de Baias, Agripina é avisada do possível atentado e segue até seu filho utilizando uma liteira; devido ao clima cordial durante o banquete, seus medos foram dissipados. O plano do assassinato não havia funcionado, Nero se vê desesperado e questiona Sêneca e Burro sobre o fato, escutando

\footnotetext{
292 Tac. Ann. 14, 1.

293 BARRETT, Anthony A. (1996). op. cit., p. 182. ALEXANDER, William Hardy. The Communiqué to the Senate on Agrippina's Death. CPh, v. 49, n. 2 (Apr., 1954), p. 94. DAWSON, Alexis. Whatever Happened to Lady Agrippina? CJ, v. 64, n. 6 (Mar., 1969), p. 260.

${ }_{294}^{2}$ Tac. Ann. 14, 2.
} 
que os soldados não a matariam por serem fieis à memória de Germânico; 0 imperador então se vale da chegada do liberto para acusar sua mãe de assassinato ${ }^{295}$.

Mesmo com certa dramaticidade na descrição dos momentos finais de Agripina, Tácito informa que outrora, quando ela consultava sobre o futuro de Nero os Caldeus haviam respondido que ele governaria, porém a mataria; ela então respondeu que matasse, contanto que governasse ${ }^{296}$. Este trecho mostra mais uma vez a enorme vontade de colocar o filho no poder, não importando a perda de sua própria vida para alcançar o objetivo.

As declarações presentes na carta enviada ao Senado por Nero são descritas por Tácito no trecho a seguir:

Ele anexou uma lista de acusações retiradas de um passado mais remoto: - "Ela tinha a esperança de uma parceria no principado; as cortes pretorianas deveriam jurar fidelidade a uma mulher, submeteria o Senado e o povo a uma mesma ignomínia. Então, sua ambição se frustrou, ela se voltou contra os soldados, o Senado e o povo. Havia se oposto aos donativos e às distribuições de víveres, e trabalhou para a ruína de cidadãos eminentes; que muito lhe custou impedi-la de se apresentar na porta do Senado para participar da audiência com os povos estrangeiros!". Ele fez um ataque indireto ao período de Cláudio também, transferindo todos os escândalos do reinado para a conta de sua mãe, cuja morte ele atribuiu à fortuna pública. (Tac. Ann. 14, 11, 1-3)

Neste excerto é possível notar que ela ultrapassou os limites femininos envolvendo-se com as cortes pretorianas que deviam lhe prestar juramento. Mais ainda, o imperador a acusa de querer parceria no poder e relembra sua tentativa de participar do encontro com os emissários Armênios. Ele destaca as atitudes de Agripina que desrespeitavam o âmbito masculino; ela se envolvia com questões militares e políticas.

Tácito informa que após seu óbito alguns de seus inimigos, e que estavam diretamente ligados aos últimos ataques, puderam retornar a Roma. Júnia Silana e Calpúrnia puderam retornar à cidade de Roma; os libertos Itúrio e Calvíno foram absolvidos de suas penas ${ }^{297}$. Este ponto mostra que após a defesa dos ataques realizados contra ela por Domícia e Silana, Agripina

\footnotetext{
295 Tac. Ann. 14, 3-7.

296 Tac. Ann. 14, 9, 6.

297 Tac. Ann. 14, 12, 5-7.
} 
conseguiu recuperar parte de sua influência e que os acusadores teriam sido punidos, assim como o trecho destacava, alguns de seus amigos receberam benefícios de Nero. Está foi a última vez em que sua influência sobre o filho foi sentida.

Agripina morreu no ano de 59 d.C. e certamente foi uma das mulheres que melhor compreendeu a dinâmica palaciana e soube fazer uso desta para estar ligada ao poder. Ela exerceu influência sobre o filho durante alguns anos de seu principado. Mesmo que Tácito e Suetônio não a vejam de uma forma positiva, devemos considerar que ela é um excelente exemplo da participação feminina no jogo político romano. Agripina ajudou amigos, viu-se livre de inimigos e esteve ao lado de três imperadores - seu irmão, seu marido e seu filho. Estes três imperadores puderam usar a imagem familiar - como a propaganda de Calígula e o uso de Cláudio do vínculo com Augusto - e os favores desta mulher em suas questões políticas. Após sua morte, Nero pode terminar seu casamento com Otávia, que era muito estimada por sua mãe, acusando-a de adultério e de abortar o fruto deste relacionamento e a exilou, sendo posteriormente assassinada ${ }^{298}$.

Agripina Menor em sua vida soube influenciar os governantes romanos. O uso das mulheres da família não era uma novidade; ela havia sido criada dentro de uma família que era constantemente destacada, seja nas estátuas, nas construções, ou mesmo nos eventos públicos. A relação familiar de sua mãe, Agriína Maior, com o imperador Tibério é crucial para compreender a dinâmica palaciana e o entendimento da política pela própria Agripina Menor. Ela recebeu diversas honras e esteve ao lado dos imperadores em momentos importantes, sendo conhecida e admirada pelo povo romano até o momento em que sofreu as consequências das suas intervenções.

${ }^{298}$ Tac. Ann. 14, 63, 1. DIXON, Suzanne ( 2007). op. cit., p. 61. 


\section{Conclusão}

Quando se conhece um pouco das histórias dessas mulheres por meio das fontes vemos que ainda existem muitas lacunas, nos faltam muitas informações, especialmente sobre seu cotidiano; entretanto não se pode negar que elas aparecem em uma situação política de extrema relevância. As mulheres da domus Augusta participaram do processo de criação da família, de obtenção de apoios políticos por meio de seus casamentos e, ainda, estiveram diretamente envolvidas em questões sucessórias.

Lívia e Agripina são descritas de forma semelhante: as duas mulheres são consideradas responsáveis pela adoção de seus filhos pelos maridos imperadores; estão ligadas aos acontecimentos durante a morte deles, cercando a casa e emitindo notas otimistas até que seus filhos sejam declarados imperadores. Por fim, as duas interferem de alguma maneira no principado dos filhos.

Lívia é representada de forma mais positiva, mesmo exercendo influência sobre o marido. Suas requisições são para atender amigos, familiares e pessoas que se aproximaram dela para chegar até o imperador. Seus auxílios e participações públicas têm relação com a cidade de Roma, como doações, embelezamentos e ajudas em casos de incêndios. $O$ trecho de Suetônio que a coloca ajudando no combate ao incêndio junto da população e soldados é o único trecho que mostra uma interferência não adequada para uma mulher. De acordo com o texto ela aparece estimulando as pessoas a continuarem tentando combater o fogo e não ela própria tentado apagar as chamas; como não possuímos maiores informações, não podemos saber se Augusto reprovava tal ação, assim como Tibério o fazia. Todavia, Suetônio faz uso desta informação de forma a compor sua narrativa sobre os conflitos entre mãe e filho.

Durante a cena da morte de Augusto, como destacamos, sua atitude foi adequada quando pensamos na memória familiar deles; Agripina faz o mesmo que sua bisavó, ordenando o cercamento e o envio de notícias otimistas, que poderiam ser, também, uma forma de manter a segurança. A questão do envenenamento de Augusto não parece possível se considerarmos apenas o 
gosto dele por figos e a ligação de Lívia com o cultivo do fruto, informados respectivamente por Suetônio e Plínio; apenas Dion aponta essa possibilidade de envenenamentos; Tácito informa que algumas pessoas desconfiaram de Lívia, mas não esmiúça esta informação; Suetônio coloca Lívia próxima do marido na cena de morte, sem acusá-la.

Durante o período de Tibério, Lívia continua ajudando amigos e exercendo sua influência; entretanto, sua ajuda não coloca os amigos em cargos específicos no governo, ou se ajuda suas carreiras, ela não aparece cobrando favores destes. Segundo as fontes, o único caso que ela se vale dos favores prestados é com o imperador; ela relembra o filho que ele devia sua posição a ela após ter um dos seus pedidos recusados. Na Vida de Tibério, Suetônio apresenta uma Lívia como uma mãe que fazia uso de sua influência e posição para conseguir que seus pedidos fossem realizados; todavia, excluindo-se o conflito com o filho, ela não é mostrada cobrando favores.

As primeiras intrigas e questões conflituosas do palácio podem ser vistas desde o período de Augusto, com o controle dos casamentos das mulheres e os banimentos de familiares por seu comportamento e relacionamentos. Augusto baniu a filha Júlia, sua neta Júlia II e seu neto e filho adotivo Agripa Póstumo. Porém, tudo isso ainda é tratado como estando dentro do controle do paterfamilias, o controle de Augusto. Durante o principado de Tibério, os conflitos com Germânico e Agripina Maior ganham uma proporção maior, na qual a admiração que a população romana sentia pelo casal foi conhecida em alguns momentos.

A criação de uma família utilizando casamentos endogâmicos e a inclusão de outras famílias, especialmente a de Lívia, formou a domus Augusta. Este grupo reforçou os laços com novos matrimônios ao longo dos principados da dinastia Júlio-Claudiana. Porém, somente a existência deste grupo não bastaria para compreender as relações de poder. Esta família criada por Augusto foi colocada em foco com suas atitudes, sua propaganda e até mesmo as leis de seu período. As leis do período de Augusto transformavam especialmente a vida da aristocracia em algo público. O Estado poderia punir as mulheres adúlteras e seus maridos, caso não as denunciassem; poderia indicar que um homem ou uma mulher sem filhos não receberiam 
determinadas heranças; ou que uma mulher que possuísse três ou quatro filhos poderia gerir seus próprios bens sem um tutor.

A intensa propaganda realizada, especialmente por meio de construções e representações iconográficas, permitia à população de Roma e de todo o império conhecer os integrantes da família, seus filhos, seus feitos e observálos em público nos eventos. O velório de Druso mostra que as pessoas observavam as atitudes de Lívia, assim como observaram a chegada à Roma de Agripina Maior com as cinzas de seu marido Germânico. Observavam o recebimento da toga viril pelos jovens da família, como se portavam nos eventos e comentavam sobre eles; a memória de Druso entre o povo romano transferiu-se para seu filho Germânico e aos seus descendentes. E ao longo da dinastia Júlio-Claudiana os membros da família, homens ou mulheres, buscaram relembrar esses parentes aclamados, especialmente Augusto. Uma prática comum dos romanos: a valorização dos ascendentes relevantes como forma de valorização pessoal.

A partir das relações familiares com Agripina Maior, a percepção da dinâmica palaciana vai se tornando mais clara, mas ainda estamos num processo inicial. Pensemos em Augusto: ele continuou usando a estrutura republicana, mantendo a imagem de que não desrespeitava as tradições, porém aos poucos foi aceitando títulos e poderes que vão permitir que haja sucessão. O mesmo ocorre com a compreensão do papel das mulheres da domus Augusta. No começo do principado de Tibério, Lívia só possuía as honras dadas por seu marido e então o Senado propõe a construção de um altar e alguns títulos, um reflexo direto da propaganda augustana e da relevância adquirida por ela. Todavia, algumas dessas honras eram estranhas aos romanos e por isso não foram aceitas, Tibério deixa claro que teria cuidado ao aceitar para a mãe e para si próprio essas honras. Já sob Calígula e Cláudio as honras dadas às mulheres não possuem questionamentos ou comentários como os feitos por Tibério, presente nas fontes primárias. Agripina Menor se torna Augusta após a adoção de seu filho: uma honra que Lívia só veio a receber depois da morte do marido e em sua adoção na família Júlia. No principado de Cláudio, sua esposa Agripina ganha o direito de usar o carpentum e esta honra é descrita por Tácito como algo que realçava a veneração dedicada a uma mulher que possuía uma ascendência notável. 
Nos principados de Calígula, Cláudio e Nero o número de boatos e comentários sobre relacionamentos - amorosos ou familiares - de pessoas da família ou ligadas a ela é grande. Tácito e Suetônio incluem passagens sobre perseguições a familiares, ódios e intrigas entre as mulheres. Mas como destacamos, estas pessoas perseguidas estavam de alguma forma se mostrando como possíveis concorrentes ao poder. A própria construção da domus Augusta possibilitava que indivíduos aparentemente não ligados à linha sucessória se encontrassem, após a morte de um parente, como possíveis imperadores ou esposas, irmãs e mães de imperadores. Esta morte poderia ser acidental ou um assassinato que visava esta posição sucessória ou a segurança da posição de imperador, ou de esposa do governante. O caso das visitas constantes de Livila ao tio e imperador, Cláudio, levou ao seu exílio e morte, pois ela representou um risco à Messalina - que é acusada de ser a responsável por esse exílio. A população comentou a possível tentativa de assassinato contra Nero, em sua infância, e Agripina Menor fez uso do boato para destacar seu filho como possível candidato a sucessão, ou ao menos indicar que sua ascendência nobre o colocava em uma posição invejável tendo em vista que Nero seria um possível concorrente de Britânico (filho do imperador), ou ainda, Agripina possuindo um filho com tão nobre origem representava um grande perigo para a posição de Messalina.

Agripina é considerada uma mulher que faria qualquer coisa pelo poder; seus relacionamentos são pensados pela fortuna dos maridos e suas posições. Ela foi acusada de ser uma adúltera e de assassinar os maridos, além de promover a morte de possíveis concorrentes ao poder de seu marido - ou já pensando em seu filho no poder. Até mesmo suas amizades envolvem questões de poder e dinheiro. Ela também é descrita como uma madrasta, e desde os questionamentos do casamento dela com Cláudio pelos libertos, na descrição de Tácito, vemos esta preocupação; no texto do historiador temos alguns exemplos dos atos da madrasta para excluir, especialmente, Britânico da possibilidade de sucessão, o que nos leva novamente às relações palacianas. Mireille Corbier nos informa que Calígula, Cláudio e Nero não possuíam experiência militar, passando diretamente da vida no palácio ao 
poder $^{299}$. Isto explica o considerável número de intrigas e boatos que permeiam as descrições destes imperadores e de seus familiares.

Sobre o filho de Agripina, havia boatos indicando que Nero era influenciado por sua mãe e por suas amantes, além dos questionamentos de sua idade; outros conflitos, que são apenas dados como intrigas, mostram o funcionamento das diversas relações palacianas. Agripina Menor compreendeu quem ela era assim como sua mãe Agripina Maior; entretanto, ela soube lidar com a dinâmica palaciana em que ela nasceu e foi criada, até o momento em que suas relações e amizades tornaram-se uma ameaça ao poder do próprio filho.

Lívia e Agripina Menor são mulheres relevantes e que estiveram ao lado dos imperadores da dinastia Júlio-Claudiana. A imagem delas foi utilizada, para a construção de uma família, para um exemplo de comportamento ou ainda para vincular-se a Augusto, como no caso de Cláudio. Todavia, o uso da imagem destas mulheres tornou suas vidas, suas participações em eventos públicos e a postura adotada por elas conhecidas pela população romana.

Apesar das representações destas mulheres feitas pelas fontes primárias, seus títulos e honras, bem como suas representações iconográficas não foram criados por autores antigos. A influência e a participação destas mulheres estão presentes nas fontes; em alguns pontos idealizados ou como parte de algum estereótipo, em outros pontos uma referência pontual e sutil nos mostra estas mulheres tão relevantes. Se não considerarmos a formação da domus Augusta e a propaganda imperial talvez estas mulheres permaneçam apenas como estereótipos, utilizados pelos autores para assegurar a compreensão das ideias de seus textos.

${ }^{299}$ CORBIER, Mireille. Poder e parentesco. A família Júlio-Cláudia. Tradução de Consuelo Fontes Santiago. Classica, São Paulo, 5/6, 1992/1993, p. 193-194. 


\section{Referências bibliográficas}

\subsection{Fontes Primárias}

DIO CASSIUS. Roman History. Translated by Earnest Cary. London: Loeb Classical Library, 1927. v. I-XI.

PLUTARCH. Lives. Translated by Bernadotte Perrin. London: Loeb Classical Library, 1920. v. IX.

SUETONIO. Vida de los doce Césares. Traducción y notas de Rosa María Agudo Cubas. Madrid: Editorial Gredos, 1992. (Biblioteca clásica Gredos 167168)

SUETONIUS. The Lives of the Caesars. With an English translation by J.C. Rolfe. Cambridge; Massachussetts; London, England: Harvard University Press, [s.d.]. v. I-II.

TACITE. Annales. Texte établi et traduit par Henri Goelzer. Paris: Société d'édition "Les Belles Lettres", 1953. 3v.

TACITUS. The Annals. Translated by Jackson, J. London: Loeb Classical Library, 1931. v. III-V.

VELLEIUS PATERCULUS. Compendium of Roman History. Res Gestae Divi Augusti. Translated by Frederick W. Shipley. London: Loeb Classical Library, 1920. v. IX.

\subsection{Obras Gerais}

ALEXANDER, William Hardy. The Communiqué to the Senate on Agrippina's Death. Classical Philology, v. 49, n. 2 (Apr., 1954), p. 94-97.

ALFÖLDY, Géza. A História Social de Roma. Lisboa: Presença, 1989.

AVELINE, John. The Death of Claudius. Historia: Zeitschrift für Alte Geschichte, v. 53, n. 4 (2004), p. 453-475.

BAKHTIN, Mikhail. Questões de literatura e de estética: a teoria do romance. Traduzido por Aurora Fornoni Bernardini et al. São Paulo: Hucitec, 2002.

BARRETT, Anthony A. Agrippina: sex, power, and politics in the Early Empire. London: Routledge, 1996.

University Press, 2002.

Livia: First Lady of Imperial Rome. New Haven: Yale 
BARRETT, Anthony A. The Year of Livia's Birth. The Classical Quarterly, New Series, v. 49, n. 2 (1999), p. 630-632.

BAUMAN, R. A. Tanaquil-Livia and the Death of Augustus. Historia: Zeitschrift für Alte Geschichte, v. 43, n. 2 (2nd Qtr., 1994), p. 177-188.

BENARIO, Herbert W. Tacitus and the Principate. The Classical Journal, v. 60, n. 3, Dec. 1964, p. 97-106.

BICKNELL, P. J. Agrippina's Villa at Bauli. The Classical Review, New Series, v. 13, n. 3 (Dec., 1963), p. 261-262.

BRADLEY, K.R. Remarriage and Structure of the Upper-Class. In: RAWSON, Beryl (ed.). Marriage, divorce, and children in Ancient Rome. Canberra, Oxford: Humanities research Centre, Clarendon Press, 1991, p. 79-98.

BRANDÃO, José Luís Lopes. Máscaras dos Césares: Teatro e Moralidade nas "Vidas" Suetonianas. Coimbra: Centro de Estudos Clássicos e Humanísticos, 2009.

CARCOPINO, J. Roma no apogeu do Império Romano. Tradução Hildegard Feist. São Paulo: Companhia das Letras/ Círculo do Livro, s/d. (A vida quotidiana)

CASTRO, Flávia Lages de. Mulheres Romanas. Rio de Janeiro: Lumen Juris, 2004.

CAZENAVE, Michel e AUGUET, Roland. Os imperadores loucos: Ensaio de mito-análise histórica. Portugal: Inquérito, [s.d.].

CIZEK, Eugen. Structures et idéologie dans "Les vies des douze Césars" de Suétone. Bucuresti: Editura Academiei; Paris: Les Belles lettres, 1977.

CORASSIN, M. L.. Sociedade e política na Roma Antiga. São Paulo: Atual, 2001.

CORBIER, Mireille. Poder e parentesco. A família Júlio-Cláudia. Tradução de Consuelo Fontes Santiago. Classica, São Paulo, 5/6, 1992/1993, p.167-203.

Divorce and adoption as familial strategies. In: RAWSON, Beryl (ed.). Marriage, divorce, and children in Ancient Rome. Canberra, Oxford: Humanities research Centre, Clarendon Press, 1991.

DAWSON, Alexis. Whatever Happened to Lady Agrippina? The Classical Journal, v. 64, n. 6 (Mar., 1969), p. 253-267.

DECKMAN, Alice A. Livia Augusta. The Classical Weekly, v. 19, n. 3 (Oct. 19, 1925), pp. 21-25. 
DIXON, Suzanne. Reading Roman women: sources, genres and real life. London: Duckworth, 2007.

. The Roman Family: Ancient Society and History. Baltimore, Londres: The Johns Hopkins University Press, 1991.

. The Roman Mother. London: Routledge, 1990.

.The Sentimental Ideal of The Roman Family. In: RAWSON, Beryl (ed.). Marriage, divorce, and children in Ancient Rome. Canberra, Oxford: Humanities research Centre, Clarendon Press, 1991, p. 99-113.

DOREY, T. A. (ed.). Latin Biography. London: Routledge, 1967.

DUBY, G. \& PERROT (Dir.). História das Mulheres no Ocidente. Vol. 1. A Antigüidade. Porto: Ed. Afrontamento, 1990.

EDER, Walter. Augustus and the Power of Tradition. IN: GALINSKY, Karl (ed.). The Cambridge Companion to The Age of Augustus. New York: Cambridge University Press, 2005.

ERHART, K. Patricia. A New Portrait Type of Octavia Minor. The J. Paul Getty Museum Journal, v. 8 (1980), p. 117-128.

ESDAILE, Katharine A. The Aged Livia. The Journal of Roman Studies, v. 4, Part 2 (1914), p. 139-141.

EYBEN, Emiel. Fathers and Sons. In: RAWSON, Beryl (ed.). Marriage, divorce, and children in Ancient Rome. Canberra, Oxford: Humanities research Centre, Clarendon Press, 1991, p. 114-143.

FANTHAM, Elaine, et al. Women in the Classical World: Image and Text. New York: Oxford University Press, 1995.

FAVRO, Diane. Making Rome A World City. IN: GALINSKY, Karl (ed.). The Cambridge Companion to The Age of Augustus. New York: Cambridge University Press, 2005.

FINLEY, M.I. A política no mundo antigo. Rio de Janeiro: Zahar, 1985.

. The Silent Women of Rome. IN: Aspects of Antiquity: Discoveries and Controversies. New York : Viking Press, 1968.

FLORY, Marleen B. Abducta Neroni uxor: The Historiographical Tradition on the Marriage of Octavian and Livia. Transactions of the American Philological Association (1974-), v. 118 (1988), p. 343-359. 
FLORY, Marleen B. Livia and the History of Public Honorific Statues for Women in Rome. Transactions of the American Philological Association (1974), v. 123 (1993), p. 287-308.

FRASCHETTI, A. Roma al femminile. Roma : Laterza, 1994.

GARDNER, Jane F. Women in Roman law \& society. London: Rouledge, 1995.

GARDNER, P. A New Portrait of Livia. The Journal of Roman Studies, v. 12 (1922), p. 32-34.

GEER, Russel Mortimer . Notes on the Early Life of Nero. Transactions and Proceedings of the American Philological Association, v. 62 (1931), p. 57-67.

GIARDINA, Andrea (Org.). O Homem Romano. Lisboa: Presença, 1992.

GILISSEN, John. Introdução Histórica ao Direito. Lisboa: Fundação Calouste Gulbenkian, 2003.

GINSBURG , Judith. Representing Agrippina: Constructions of Female Power in the Early Roman Empire. Oxford and New York: Oxford University Press, 2005.

GOUREVITCH, Danielle; RAEPSAET-CHARLIER, Marie-Thérèse A vida quotidiana: da mulher na Roma Antiga. Lisboa : Livros do Brasil, 2006.

GRETHER, Gertrude. Livia and the Roman Imperial Cult. The American Journal of Philology, v. 67, n. 3 (1946), p. 222-252.

GRUBBS, Judith Evans. Women and Law in the Roman Empire: A Sourcebook on Marriage, Divorce and Widowhood. London and New York: Routledge, 2002.

GRUEN, Erich S. Augustus and the Making of the Principate. IN: GALINSKY, Karl (ed.). The Cambridge Companion to The Age of Augustus. New York: Cambridge University Press, 2005

HEMELRIJK, Emily Ann. Matrona docta : educated women in the Roman élite from Cornelia to Julia Domna. London : Routledge, 1999.

HERSCH, Karen K. The Roman Wedding: Ritual and meaning in Antiquity. New York: Cambridge University Press, 2012.

HOPKINS, K.. Movilidad de la elite en el imperio romano. In: FINLEY, M. Estudios sobre historia antigua. Madrid, Akal Editor,1981, p. 119-136.

HUNTSMAN, Eric D. Livia before Octavian. Ancient Society, v. 39 (2009), p. 121-169. 
HUZAR, Eleanor G. Mark Antony: Marriages vs. Careers. The Classical Journal, v.81, n.2, (Dec., 1985 - Jan., 1986), p. 97-111.

JENKINS, Thomas E. Livia the Princeps Gender and Ideology in the Consolatio ad Liviam. Helios, v. 36, n. 1, Spring 2009, p. 1-25.

KATZOFF, Ranon. Where Was Agrippina Murdered? Historia: Zeitschrift für Alte Geschichte, v. 22, n. 1 (1st Qtr., 1973), p. 72-78.

L'HOIR, Francesca Santoro. Tacitus and Women's Usurpation of Power. The Classical World, v. 88, n. 1 (Sep. - Oct., 1994), p. 5-25.

LACEY, W.K. Patria Potestas. In: RAWSON, Beryl. The Family in Ancient Rome: New Perspectives. Londres: Routledge, 1992, p. 121-144.

LEVICK, B. 'Julians and Claudians'. Greece \& Rome, Second Series, v. 22, n. 1 (Apr., 1975), p. 29-38.

MARROU, Henri-Irénée. História da Educação na Antiguidade. São Paulo: Editora Pedagógica e Universitária, 1975.

MASSEY, Michael. As mulheres na Grécia e Roma antigas. Lisboa: Publicações Europa-América, 1988.

MCALINDON, D. Claudius and the Senators. The American Journal of Philology, v. 78, n. 3 (1957), p. 279-286.

Senatorial Opposition to Claudius and Nero. The American Journal of Philology, v. 77, n. 2 (1956), p. 113-132.

MCDANIEL, Walton Brooks. Bauli the Scene of the Murder of Agrippina. The Classical Quarterly, v. 4, n. 2 (Apr., 1910), p. 96-102.

MELLOR, Ronald. The Roman Historians. New York: Routledge, 1991. Tacitus. New York: Routledge, 1993.

MOMIGLIANO A..The development of Greek Biography. Cambridge, Massachusetts: Harvard University Press, 1971.

MONROE, Paul. História da Educação. São Paulo: Companhia Editora Nacional, 1978.

MORFORD, Mark P. O. The Training of Three Roman Emperors. Phoenix, v. 22, n. 1 (Spring, 1968), p. 57-72.

MULLENS, H. G. The Women of the Caesars. Greece \& Rome, v. 11, n. 32 (Feb., 1942), p. 59-67. 
MURRAY, Margaret. Royal Marriages and Matrilineal Descent. The Journal of the Royal Anthropological Institute of Great Britain and Ireland, v. 45 (Jul. Dec., 1915), p. 307-325.

PRYZWANSKY, Molly M. Feminine Imperial Ideals in the Caesares of Suetonius. Dissertation (Doctor of Philosophy) - Department of Classical Studies - Graduate School of Duke University, 2008.

RADITSA, Leo Ferrero. Augustus' Legislation concerning Marriage, Procreation, Love Affairs and Adultery. IN: Aufstieg und Niedergang der Römischen Welt: Geschichte und Kultur Roms im Spiegel der neueren Forschungen, II.13. Principat - Recht (Normen, Verbreitung, Materien). Ed. Hildegard Temporini. Berlin: De Gruyter, 1980.

RAMSBY, Teresa R; SEVERY, Beth. Gender, Sex, and the Domestication of the Empire in Art of the Augustan Age. Arethusa, v. 40, n. 1, Winter 2007, p. 43-71.

RAUBITSCHEK, Antony E. Octavia's Deification at Athenas. Transactions of the American Philological Association, v.77, 1946.

RAWSON, Beryl. Children in The Roman Familia. In: RAWSON, Beryl. The Family in Ancient Rome: New Perspectives. Londres: Routledge, 1992, p. 170-200.

Adult-Child Relationships in Roman Society. In: RAWSON, Beryl (ed.). Marriage, divorce, and children in Ancient Rome. Canberra, Oxford: Humanities research Centre, Clarendon Press, 1991, p. 7-30.

ROGERS, Robert Samuel. The Conspiracy of Agrippina. Transactions and Proceedings of the American Philological Association, v. 62 (1931), p. 141-168.

ROLFE, John C. Suetonius and His Biographies. Proceedings of the American Philosophical Society, v. 52, n. 209, Apr., 1913, p. 206-225.

ROPER, Theresa K. Nero, Seneca and Tigellinus. Historia: Zeitschrift für Alte Geschichte, v. 28, n. 3 (3rd Qtr., 1979), p. 346-357.

RUTLAND, Linda W. Women as Makers of Kings in Tacitus' Annals. The Classical World, v. 72, n. 1 Sep., 1978, p. 15-29.

SHOTTER, David C. A. Agrippina the Elder: A Woman in a Man's World. Historia: Zeitschrift für Alte Geschichte, v. 49, n. 3 (3rd Qtr., 2000), p. 341-357.

SINGER, Mary White. Octavia's Mediation at Tarentum. The Classical Journal, v. 43, n. 3 (Dec., 1947), p. 173-178.

The Problem of Octavia Minor and Octavia Maior. Transactions and Proceedings of the American Philological Association, v. 79 (1948), p. 268-274. 
SMITH, Cecil H. A Portrait Bust of Agrippina. The Burlington Magazine for Connoisseurs, v. 11, n. 50 (May, 1907), p. 99-101.

SYME, Ronald. Princesses and Others in Tacitus. Greece \& Rome, Second Series, v. 28, n. 1, Jubilee Year (Apr., 1981), p. 40-52.

TREGGIARI, Susan. Divorce Roman Style: Ease and frequency. In: RAWSON, Beryl (ed.). Marriage, divorce, and children in Ancient Rome. Canberra, Oxford: Humanities research Centre, Clarendon Press, 1991.

VARNER, Eric R. Portraits, Plots, and Politics: "Damnatio memoriae" and the Images of Imperial Women. Memoirs of the American Academy in Rome, v. 46 (2001), p. 41-93.

VEYNE, P. "O império romano". In: ARIÉS, Ph; DUBY, G. (Dir.) História da vida privada. São Paulo: Companhia das Letras, 1991. v. 1.

WEAVER, P. R. C.. Movilidad social en el alto imperio romano: la evidencia de los libertos imperiales y los esclavos. In: FINLEY, M. Estudios sobre historia antigua. Madrid, Akal Editor, 1981, p. 137-156.

WIEAND, Helen E. The Position of Women in the Late Roman Republic. Part II. The Classical Journal, v. 12, n. 7 (Apr., 1917), p. 423-437.

WOOD, Susan. Memoriae Agrippinae: Agrippina the Elder in Julio-Claudian Art and Propaganda. American Journal of Archaeology, v. 92, n. 3 (Jul., 1988), p. 409-426. 


\section{ANEXO I}

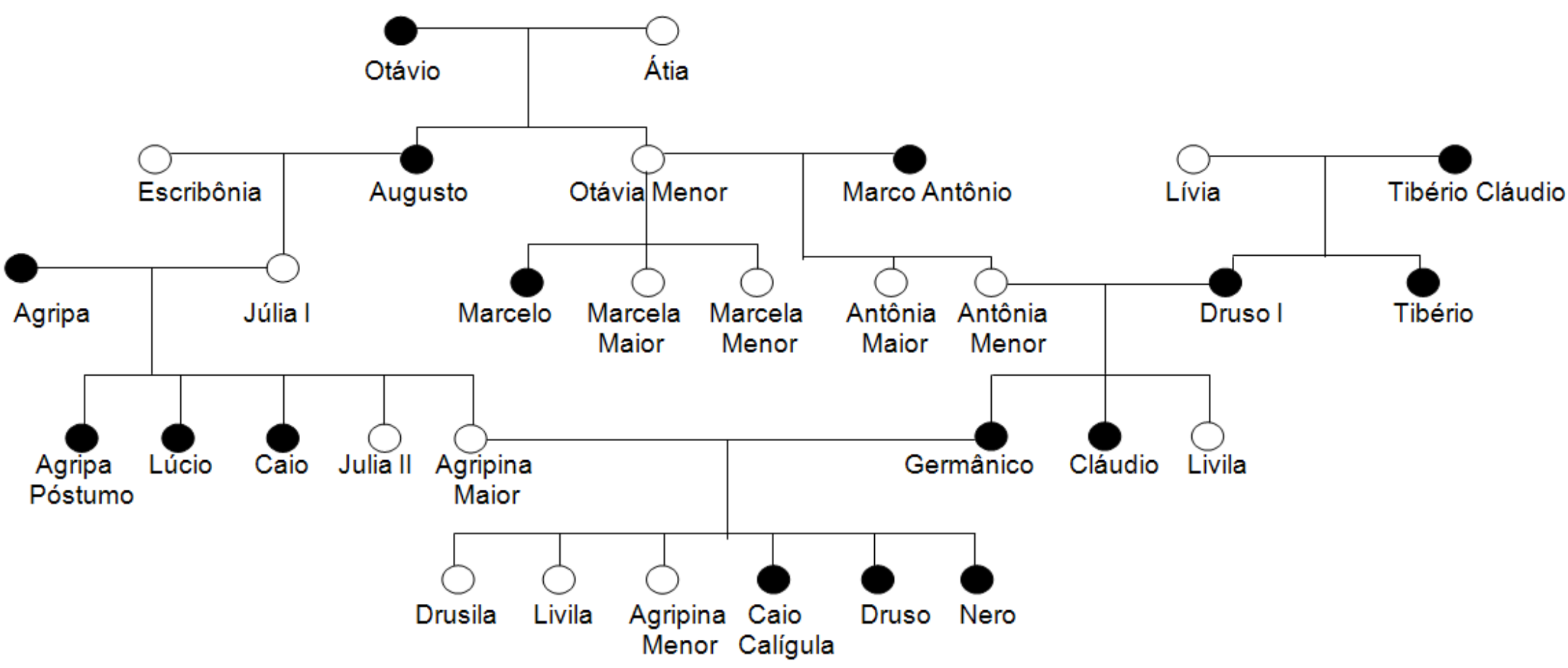




\section{ANEXO II}

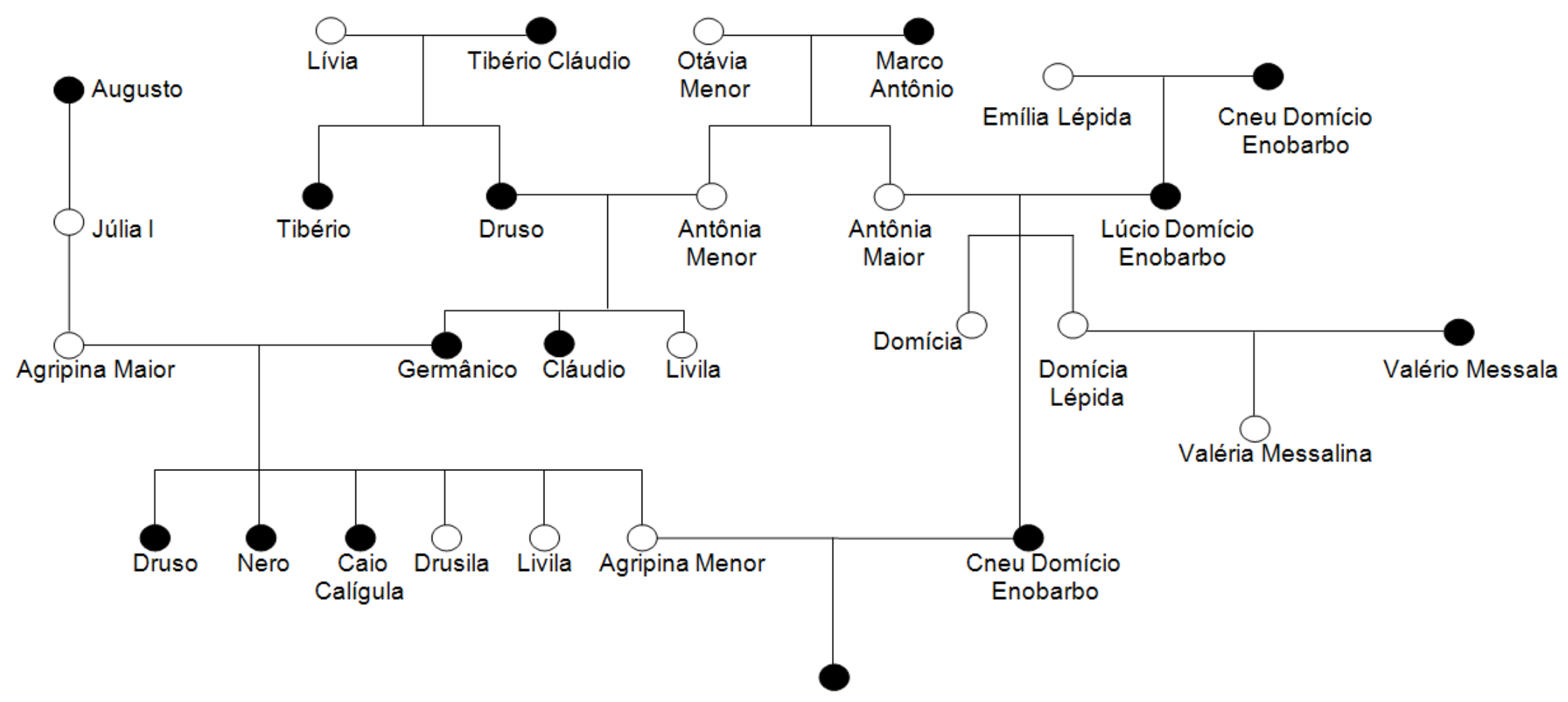

Lúcio Domício Enobarbo

(Nero) 


\section{ANEXO III}
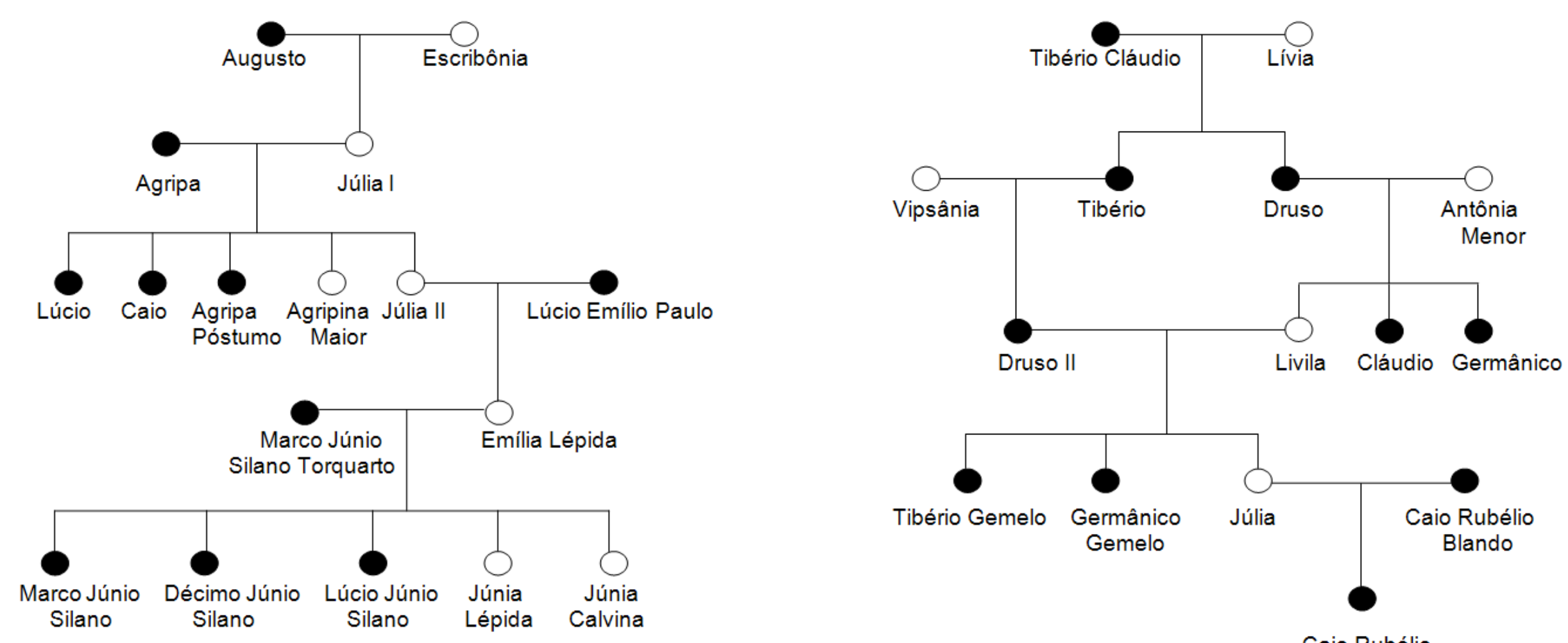

Caio Rubélio

Plauto 